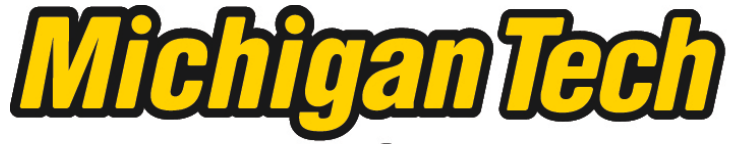 \\ Michigan Technological University Create the Future Digital Commons @ Michigan Tech
}

Dissertations, Master's Theses and Master's Reports - Open

Dissertations, Master's Theses and Master's

Reports

2013

\section{A COST-BENEFIT ANALYSIS OF A 25\% RPS IN MICHIGAN}

Fei Li

Michigan Technological University

Follow this and additional works at: https://digitalcommons.mtu.edu/etds

Part of the Economics Commons, and the Energy Policy Commons Copyright 2013 Fei Li

\section{Recommended Citation}

Li, Fei, "A COST-BENEFIT ANALYSIS OF A 25\% RPS IN MICHIGAN", Master's Thesis, Michigan Technological University, 2013.

https://doi.org/10.37099/mtu.dc.etds/656

Follow this and additional works at: https://digitalcommons.mtu.edu/etds

Part of the Economics Commons, and the Energy Policy Commons 


\title{
A COST-BENEFIT ANALYSIS OF A 25\% RPS IN MICHIGAN
}

By

Fei Li

\begin{abstract}
A THESIS
Submitted in partial fulfillment of the requirements for the degree of MASTER OF SCIENCE

In Environmental and Energy Policy
\end{abstract}

MICHIGAN TECHNOLOGICAL UNIVERSITY

2013

(C) 2013 Fei Li 
This thesis has been approved in partial fulfillment of the requirements for the Degree of MASTER OF SCIENCE in Environmental and Energy Policy.

Department of Social Sciences

\author{
Thesis Advisor: $\quad$ Barry D. Solomon \\ Committee Member: $\quad$ Adam M. Wellstead \\ Committee Member: $\quad$ Mark C. Roberts \\ Department Chair: Patrick E. Martin
}




\section{Table of Contents}

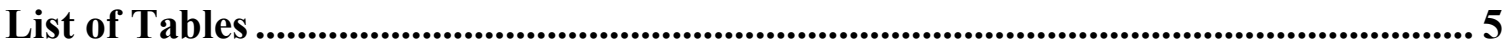

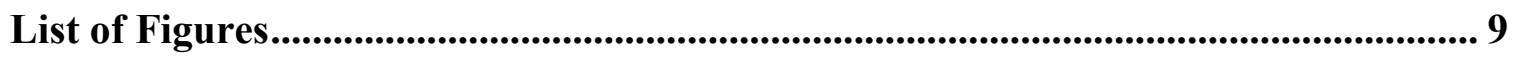



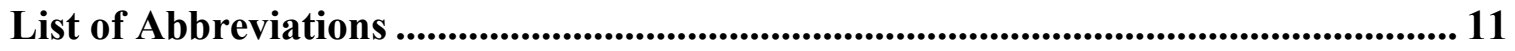

Abstract................................................................................................................................ 13

Chapter 1: Introduction ........................................................................................................ 14



1.2 Literature Review, Study Purpose and Methods............................................... 18

Chapter 2: Electric Generation Cost of a 25\% RPS and its Impacts on Ratepayers'

Electricity Bills ....................................................................................................................... 22

2.1 Projecting Future Renewable Electricity Generation ....................................... 22

2.2 The Cost of Renewable Electricity Generation Under a 25\% RPS ...................... 31



2.4 Impacts on Ratepayer's Electricity Bills.................................................. 44

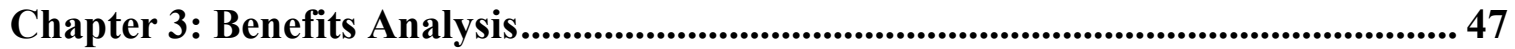

3.1 The Avoided Electricity Generation Cost and the Net Generation Cost ............... 47

3.2 Environmental and Human Health Benefits of a 25\% RPS................................ 58

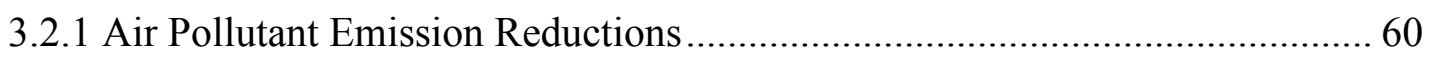

3.2.2 Human Health and Environmental Benefits from Air Pollutant Emission



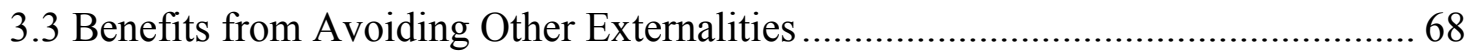

Chapter 4: Conclusion and Discussion .................................................................... 74

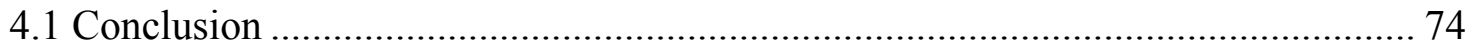

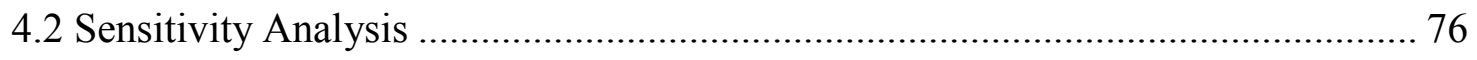

4.3 Limitation and the Implication for Future Studies........................................ 78 


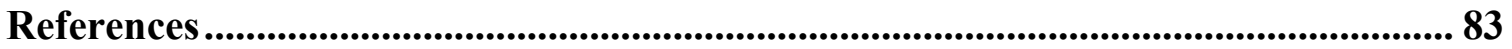

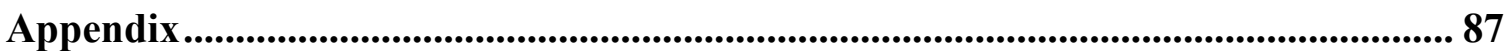




\section{List of Tables}

Table 1.1: Total Estimated Renewable Energy Technical Potential in the U.S. and



Table 2.1: Electricity Sales Projection from 2016 to 2025 in Michigan .......................... 23 Table 2.2: Required Renewable Electricity Sales in Michigan Under Different Scenarios

Table 2.3: The Renewable Electricity Sales Under the Current 10\% RES in Michigan .. 28

Table 2.4: The Renewable Electricity Sales Under a $25 \%$ RPS in Michigan. 29

Table 2.5: Additional Required Renewable Electricity Sales due to a 25\% RPS in Michigan 30

Table 2.6: Levelized Cost of Power Plant for Different Technologies in the U.S. ......... 32

Table 2.7: The Best Estimate of LECs of Power Plants in the U.S. 34

Table 2.8: Additional Required Renewable Electricity Generation due to a 25\% RPS in Michigan 36

Table 2.9: Total Renewable Electricity Generation Under a 25\% RPS in Michigan ....... 36 Table 2.10: Total Renewable Electricity Generation Under the Current 10\% RES in Michigan 37

Table 2.11: The Best Estimate for the Additional Cost of Renewable Electricity 37 Generation Under a 25\% RPS in Michigan .............................................................. 37 Table 2.12: The Best Estimate for the Cost of Renewable Electricity Generation Under a $25 \%$ RPS in Michigan 38

Table 2.13: The Best Estimate for the Cost of Renewable Electricity Generation Under the Current 10\% RES in Michigan 38

Table 2.14: Current Production Tax Credits for Different Renewable Electricity Production Technologies in the U.S.

Table 2.15: Best Estimate for the Total Tax Credits Earned by Different Renewable Electricity Power Plants Under a 25\% RPS in Michigan .....

Table 2.16: The Best Estimate for the Cost of Renewable Electricity Power Plants Under a $25 \%$ RPS in Tax Credits Included Scenario

Table 2.17: The Best Estimate for the Additional Cost of Renewable Electricity Generation due to a 25\% RPS in Michigan in Tax Credits Included Scenario ................ 43

Table 2.18: The Best Estimate for the Impact on Electricity Rates in Michigan ............. 46 Table 3.1: Annual Proportion of Electricity Generated from Coal and Natural Gas in Michigan

Table 3.2: Additional Avoided Electricity Generation from Coal and Natural Gas due to a $25 \%$ PRS in Michigan. 50

Table 3.3: Average Total System LECs for Coal and Natural Gas Plants in the U.S. ..... 51 
Table 3.4: The Best Estimate for the Avoided Cost of Electricity Generation Under a $25 \%$ RPS in Michigan.

Table 3.5: The Best Estimate for the Required Backup Electricity Generation in Michigan

Table 3.6: The Best Estimate for the Cost of Backup Capacity Compensating for Intermittent Renewable Electricity Generation Technologies Under a 25\% RPS in Michigan 55

Table 3.7: The Best Estimate for the Net Renewable Electricity Generation Cost Under a $25 \%$ RPS in Michigan.

Table 3.8: The Best Estimate for the Net Renewable Electricity Generation Cost Under a 25\% RPS in Michigan (Tax Credits Included Scenario) 57

Table 3.9: Emission Factors for Different Power Plants 62 Table 3.10: Annual Avoided Pollutant Emissions Under a 25\% RPS from 2016 to 2025 in Michigan 63

Table 3.11: The Range of Potential Damage Cost for Different Pollutant Emissions ..... 65

Table 3.12: The Best Estimate for the Annual Avoided Damage Cost from Air Pollutant Emission Reductions of a 25\% RPS in Michigan. 67

Table 3.13: The Present Value Ranges for Different Types of Benefits of a 25\% RPS in Michigan Under the Best Estimate Scenario 68

Table 3.14: The Best Estimate for the Cost of Some Other Externalities for Electricity Generation Alternatives 70

Table 3.15: The Best Estimate for the Annual Benefit from the Net Avoided Cost of Other Externalities Under a 25\% RPS in Michigan..... 73

Table 3.16: Present Value of the Total Benefits of a 25\% RPS in Michigan from 2016 to 2025 73

Table 4.1: Net Present Value of a 25\% RPS in Michigan from 2016 to 2025 ................ 75

Table 4.2: Net Present Value of a 25\% RPS in Michigan from 2016 to 2025 (Tax Credits Included Scenario) 75

Table 4.3: Sensitivity Analysis for Net Present Value of a 25\% RPS in Michigan from 2016 to 2025 With a Change of Discount Rate (r) ....

Table 4.4: Sensitivity Analysis for Net Present Value of a 25\% RPS in Michigan from 2016 to 2025 With a Change of Growth Rate (g) of Electricity Generation from Solar

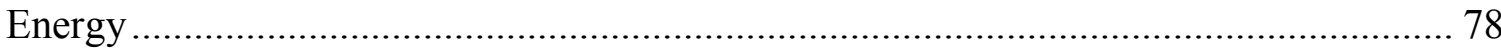

Table A1: Minimum LECs for Selected Power Plant Technologies in the U.S.............. 87

Table A2: Maximum LECs for Selected Power Plant Technologies in the U.S. ............. 87

Table A3: The Lower Range for the Present Value of the Additional Cost of Renewable Electricity Generation due to a $25 \%$ RPS in Michigan. 88

Table A4: The Upper Range for the Present Value of Additional Cost of Renewable Electricity Generation due to a 25\% RPS in Michigan 88 
Table A5: The Lower Range for the Cost of Renewable Electricity Generation Under a $25 \%$ RPS in Michigan.

Table A6: The Upper Range for the Cost of Renewable Electricity Generation Under a $25 \%$ RPS in Michigan.

Table A7: The Lower Range for the Cost of Renewable Electricity Generation Under the Current 10\% RES in Michigan 90

Table A8: The Upper Range for the Cost of Renewable Electricity Generation Under the Current 10\% RES in Michigan 90

Table A9: The Lower Range for the Total Tax Credits Earned by the Additional Renewable Electricity Generation due to a 25\% RPS in Michigan................................. 91

Table A10: The Upper Range for the Total Tax Credits Earned by the Additional Renewable Electricity Generation due to a 25\% RPS in Michigan. 91 Table A11: The Lower Range for the Total Tax Credits Earned by Different Renewable Electricity Power Plants Under a 25\% RPS in Michigan 92

Table A12: The Upper Range for the Total Tax Credits Earned by Different Renewable Electricity Power Plants Under a 25\% RPS in Michigan 92 Table A13: The Lower Range for the Present Value of the Cost of Renewable Electricity Generation Under a 25\% RPS (Tax Credits Included Scenario) 93 Table A14: The Upper Range for the Present Value of the Cost of Renewable Electricity Generation Under a 25\% RPS (Tax Credits Included Scenario)

Table A15: The Lower Range for the Additional Cost of Renewable Electricity Generation due to a 25\% RPS in Michigan (Tax Credits Included Scenario). 94

Table A16: The Upper Range for the Additional Cost of Renewable Electricity Generation due to a 25\% RPS in Michigan (Tax Credits Included Scenario).................. 94

Table A17: The Lower Range for the Impact on Electricity Rates in Michigan.............. 95

Table A18: The Upper Range for the Impact on Electricity Rates in Michigan .............. 96

Table A19: The Lower Range for the Avoided Cost of Electricity Generation Under a $25 \%$ RPS in Michigan.

Table A20: The Upper Range for the Avoided Cost of Electricity Generation Under a $25 \%$ RPS in Michigan.

Table A21: The Lower Range for the Required Backup Electricity Generation in Michigan (5\% Backup Capacity)

Table A22: The Upper Range for the Required Backup Electricity Generation in Michigan (10\% Backup Capacity).

Table A23: The Lower Range for the Cost of Backup Capacity Compensating for Intermittent Renewable Electricity Generation Technologies Under a 25\% RPS in Michigan (5\% Backup Capacity and Lower LECs) 
Table A24: The Upper Range for the Cost of Backup Capacity Compensating for Intermittent Renewable Electricity Generation Technologies Under a 25\% RPS in Michigan (10\% Backup Capacity and Upper LECs).

Table A25: The Lower Range for the Net Renewable Electricity Generation Cost Under a $25 \%$ RPS in Michigan. 100

Table A26: The Upper Range for the Net Renewable Electricity Generation Cost Under a $25 \%$ RPS in Michigan. 100

Table A27: The Lower Range for the Net Renewable Electricity Generation Cost Under a $25 \%$ RPS in Michigan (Tax Credits Included Scenario) 101

Table A28: The Upper Range for the Net Renewable Electricity Generation Cost Under a $25 \%$ RPS in Michigan (Tax Credits Included Scenario) 101

Table A29: The Lower Range for the Annual Avoided Damage Cost from Air Pollutant Emission Reductions of a 25\% RPS in Michigan. 102

Table A30: The Upper Range for the Annual Avoided Damage Cost from Air Pollutant Emission Reductions of a 25\% RPS in Michigan. 103

Table A31: The Lower Range for the Cost of Some Other Externalities for Electricity Generation Alternatives 104

Table A32: The Upper Range for the Cost of Some Other Externalities for Electricity Generation Alternatives 105

Table A33: The Lower Range of Avoided Cost of Other Externalities Under a 25\% RPS in Michigan 106 Table A34: The Upper Range of Avoided Cost of Other Externalities Under a 25\% RPS in Michigan 106 


\section{List of Figures}

Figure 1: Michigan Electricity Generation Profile for Calendar Year 2009

Figure 2: Renewable Energy Capacity by Technology Type Approved by the MPSC



Figure 3: LEC for New Power Plants (Excluding Subsidies) in 2020 and 2040 in the U.S.

Figure 4: The Best Estimate for Present Value of the Cost of Renewable Electricity Generation With/Without TCs Under a 25\% RPS in Michigan 


\section{Acknowledgements}

It would not have been possible to write this master's thesis without the help and support from the kind people around me. Several individuals have helped me make this possible. Above all, I would like to thank my mother, Liying Bi, for encouraging me to realize my dream of studying in the U.S. and her financial support for finishing my master's degree.

I offer my sincerest gratitude to my supervisor, Dr. Barry D. Solomon, for his continuous help and support during my M.S. study. This thesis would not have been completed without his instruction, patience, and encouragement. I could not have imagined having a better advisor and mentor for my M.S. study.

Besides my advisor, I would like to thank my other thesis committee members: Dr. Adam M. Wellstead and Dr. Mark C. Roberts, for their additional instructions, and for their critical and insightful comments throughout this thesis.

My deepest gratitude also goes to Dr. William S. Breffle and Dr. Gary A. Campbell for their valuable comments on the early drafts of this thesis.

Last, but by no means least, I thank my friends and classmates at MTU, especially Fangming (Cathy) Liu and Jayesh Borde, for their kindness and encouragement throughout.

Any error that may remain in this work is entirely my own responsibility. 


\title{
List of Abbreviations
}

\author{
AEO Annual Energy Outlook \\ CBA Cost Benefit Analysis \\ $\mathrm{CO}_{2}$ Carbon Dioxide
}

EIA U.S. Energy Information Administration

EPA U.S. Environmental Protection Agency

GHG Greenhouse Gas

GW Gigawatt

GWh Gigawatt Hour

ITC Investment Tax Credit

Kg Kilogram

kWh Killiowatt Hour

LCA Life Cycle Analysis

LEC Levelized Energy Cost

MPSC Michigan Public Service Commission

MWh Megawatt Hour

NOx Nitrogen Oxides

NPV Net Present Value

O\&M Operation and Maintenance

PM Particulate Matter

PV Photovoltaics

PTC Production Tax Credit

r Discount Rate

RES Renewable Energy Standard 
RPS Renewable Portfolio Standard

$\mathrm{SO}_{2}$ Sulfur Dioxide

TC Tax Credit 


\begin{abstract}
Michigan depends heavily on fossil fuels to generate electricity. Compared with fossil fuels, electricity generation from renewable energy produces less pollutants emissions. A Renewable Portfolio Standard (RPS) is a mandate that requires electric utilities to generate a certain amount of electricity from renewable energy sources. This thesis applies the Cost-Benefits Analysis (CBA) method to investigate the impacts of implementing a $25 \%$ in Michigan by 2025 . It is found that a $25 \%$ RPS will create about \$20.12 billion in net benefits to the State. Moreover, if current tax credit policies will not change until 2025, its net present value will increase to about $\$ 26.59$ billion. Based on the results of this CBA, a 25\% RPS should be approved. The result of future studies on the same issue can be improved if more state specific data become available.
\end{abstract}




\section{Chapter 1: Introduction}

\subsection{Background}

Michigan depends heavily on fossil fuels to generate electricity. In 2009, $66 \%$ of the electricity in the State was produced by burning coal and $8 \%$ of it is from natural gas (MPSC 2011). Electricity generated from other energy sources was as shown in Figure 1. There are some serious problems from using fossil fuels to power the State. The air pollution (such as $\mathrm{SO}_{2}, \mathrm{NO}_{x}$, lead, mercury, etc.) from fossil fuel combustion has negative impacts on human health and ecosystems. Also, a large quantity of greenhouse gases (GHGs) is emitted from coal-fired plants, which contributes to climate change. Renewable energy sources, such as wind power and biomass, have the following advantages compared with fossil fuels: they cannot be depleted, and they are green forms of energy that have minimal environmental impact. In order to alleviate the negative effects from climate change, protect human health from air pollution, and have a diversified and sustainable energy system, more renewable energy resources can be adopted into the current electricity generation system in Michigan.



Figure 1: Michigan Electricity Generation Profile for Calendar Year 2009 (MPSC 2011). 
According to the U.S. National Renewable Energy Laboratory ( Lopez et al. 2012), the renewable energy technical potential in Michigan is as shown in Table 1.1. Michigan is abundant in renewable energy sources, especially offshore wind power, which ranks 3rd place among all the U.S. states. The potential of other renewable energies, like rooftop solar and biopower, are also above the U.S. state average figure. However, only a very small portion of the renewable energy potential in Michigan has been tapped. According to U.S. Energy Information Administration (EIA) ${ }^{1}$, from March 2012 to March 2013, renewable electricity production excluding hydroelectric power was only about $53 \mathrm{GWh}$. This figure is much lower than the total renewable energy potential shown in Table 1.1, and thus more renewable energies can be utilized in the future.

The renewable portfolio standard (RPS) or renewable electricity standard (RES) is a mandate that requires electricity suppliers to generate a certain amount of electricity from qualified renewable energy sources such as wind, solar, biomass, and hydropower. Different states have regulations for whether one specific energy resource is regarded as a qualified renewable energy resource or not. Although no national RPS/RES has been enacted in the U.S., according to EIA, 30 states and the District of Columbia had specific renewable portfolio standards as of January 2013. State RPSs play a primary role in accelerating the development of new renewable energy in the United States. Compared with the renewable energy production tax credit, the RPS policy is more cost-effective in promoting the development of renewable energy and in reducing carbon emissions (Palmer and Burtraw 2005). By measuring the magnitude of the incentive provided by an

${ }^{1}$ See http://www.eia.gov/electricity/monthly/epm_table_grapher.cfm?t=epmt_1_14_a. Retrieved on May 7, 2013. 





RPS, Yin and Powers (2010) found that, on average, state RPS policies have significant and positive effects on renewable energy development. However, one should be cautious since the problems from the design and implementation of a RPS may distract the states from achieving the expected outcomes. There are some concerns over the implementation of a RPS, such as uncertainty in policy design or duration, inadequate or unclear policy enforcement, aggressive obligations which can be hardly achieved in some cases, lack of compliance flexibility, etc. (Wiser et al. 2007). Thus, it is important for the policymakers and regulators to be aware of the potential obstacles before they craft relevant policies and react immediately to the problems from the policy implementation.

Michigan Public Act 295, which was enacted in October 2008, requires electricity suppliers to meet $10 \%$ of their retail electricity sales from renewable energy resources by the end of 2015. Under Act 295, wind, solar thermal and photovoltaics (PV), biomass, landfill gas and hydroelectric are eligible renewable resources. According to the Michigan Public Service Commission (MPSC) (2013), electricity providers are on schedule to meet the 10\% Renewable Energy Standard (RES) target by 2015. Also, according to the electricity suppliers' current renewable energy plans, renewable electricity generation is expected to be increasing annually after 2015. In order to prompt the further development of renewable energy and create more job opportunities for the residents in Michigan, on November 6, 2012, Michiganders were offered a ballot proposal (Proposal 3) sponsored by Michigan Energy Michigan Jobs, which intended to amend the Michigan Constitution to mandate a 25\% RPS for the state's energy utilities by $2025(25 * 25$ Goal $)$. The proposal intended to add a new Section to Article 4 of the State Constitution and its main contents were as follows: 
- "Require electric utilities to provide at least $25 \%$ of their annual retail sales of electricity from renewable energy sources, which are wind, solar, biomass, and hydropower, by 2025.

- Limit to not more than $1 \%$ per year electric utility rate increases charged to consumers only to achieve compliance with the RES.

- Allow annual extensions of the deadline to meet the $25 \%$ RPS in order to prevent rate increases over the $1 \%$ limit.

- Require the State Legislature to enact additional laws to encourage the use of Michigan made equipment and employment of Michigan residents." 2

Although in September 2012 one survey from WoodTV indicated that that 55 percent of Michiganders were planning to support the ambitious Proposal $3^{3}, 62$ percent of voters in the State rejected this Proposal on Election Day.

\subsection{Literature Review, Study Purpose and Methods}

A few studies in the fall of 2012 analyzed the potential impacts of a $25 \%$ RPS in Michigan. One report from Michigan State University, which is based on economic input-output modeling, concluded that Proposal 3 would bring positive economic benefits to the State: increase $\$ 10.3$ billion investment in renewable energy and create 74,495 “job

\footnotetext{
2 These words are shown in the Ballot Proposal 3 of 2012 - Michigan House of Representatives, see http://www.house.mi.gov/hfa/PDFs/Ballot\%20Proposal\%202012-3.pdf. Retrieved on July 4, 2013. And the full Proposal 3 can be found on Michigan government website: http://www.michigan.gov/documents/sos/Full_Text_-_MI_Energy_MI_Jobs_399441_7.pdf. Retrieved on July 4, 2013.

${ }^{3}$ See http://www.woodtv.com/news/politics/poll-voters-favors-3-mich-proposals. Retrieved on July 4, 2013.
} 
years" from renewable energy projects by the year 2025 (Calnin et al. 2012). However, the findings from Mackinac Center and Beacon Hill Institute indicate that a 25\% RPS can cause great economic losses for the State. In the reports, the authors initially calculated the possible impacts on ratepayers' electricity bills from Proposal 3. Then, the author applied their self-developed STAMP ${ }^{\circledR}$ model, which is a computable generalized equilibrium model, to estimate the potential economic effects of a $25 \%$ RPS. The results indicated that if the proposal were passed, it would cost Michigan $\$ 2.55$ billion, increase Michigan's electricity prices by $16.2 \%$, cause 10,540 job losses, lower State disposable income by $\$ 1.42$ billion, and reduce net investment in Michigan by $\$ 147$ million (Tuerck et al. 2012). A third study from the University of Chicago discussed the potential of reducing the costs by utilizing wind power out of Michigan and the impacts on the implementation of RPS from the fixed cost cap (Moyer et al. 2012). All the above studies discussed the impacts of the $25 \%$ RPS only from economic perspectives.

However, to have a comprehensive view of the issue, some other impacts of a potential 25\% RPS in Michigan should also be considered. For example, it is known that during electricity generation, there is less pollution emitted from renewable energies than fossil fuels. It is important to understand how many pollutant emissions can be reduced and what human health and environmental benefits can be gained from avoiding the emissions. To incorporate the above aspects into consideration and test whether a $25 \%$ RPS in Michigan should be approved or not, Cost-Benefit Analysis (CBA) will be adopted in this thesis. CBA is a popular method that can shed light on whether a specific policy should be accepted by comparing its benefits and costs. One can add up the benefits and costs of the policy on a net present value basis and compare them. If the 
benefits exceed the costs, the policy makes society better off. Otherwise, the society is worse off if the policy is mandated (Hanley and Barbier 2009). By applying CBA methods, Johnson (2009) found that the wind turbine project in Principia College, which is a small college in Illinois, could generate positive net present values: \$1.02 million and $\$ 2.39$ million for a 20 -year and a 30-year scenario, respectively.

Although Proposal 3, which advocated a 25\% RPS in Michigan, was not passed, a higher RPS could still encourage renewable energy development, diversify the energy system, reduce dependence on importing energy fuels (especially coal) outside the State, and avoid pollutant emission and negative environmental impacts from burning fossil fuels in the long run. The main purpose of this thesis is to test whether implementing a 25\% RPS by 2025 in Michigan is reasonable or not by using CBA criteria. The scope of the study lies in Michigan, that is, only the benefits and costs to the residents of Michigan are considered in this thesis.

The rest of this thesis is organized as follows: Chapter 2 estimates the cost of a $25 \%$ RPS. For purpose of the study, the total electricity generation cost, which accounts for most of the cost of a $25 \%$ RPS, is approximated as the total cost. Here, EIA's levelized energy cost (LEC) approach, which incorporates almost all the aspects of electricity generation, is adopted when calculating the cost of the electricity generated from renewable energy when fulfilling utilities' obligations under the $25 \%$ RPS. For the uncertainties of the future tax credit policies for renewable energy projects, costs will be estimated under scenarios with and without a tax credit. Besides the cost analysis, the impact of the higher RPS on customers' electricity bills is also included in this section. Chapter 3 will mainly analyze the potential benefits from a 25\% RPS. The discussion in 
this section is based on the externalities of electricity generation from different energy resources. The benefits are categorized in the following groups: 1) Avoided cost of generating electricity from fossil fuel without a 25\% RPS; 2) Environmental and human health benefits; and 3) Other avoided external costs. Although electricity produced from renewable energy sources, like wind power and solar energy, generates zero emissions, electricity from renewable energy resources still have some negative externalities from the electricity generation process. For example, the residents who live near a wind farm may complain about the noise from the operating wind turbines. These should be considered as well. Thus, the external cost of renewable electricity generation will be shown in Chapter 3 (benefits analysis) instead of Chapter 2 (cost analysis). Finally, Chapter 4 will present my conclusions and some discussion. These will be based on the final results of the study and sensitivity analysis. Additionally, the limitation of the study and implications for the future research will be presented in this chapter. The estimated lower and upper ranges of all the calculations of the thesis are presented in the Appendix of this thesis. 


\section{Chapter 2: Electric Generation Cost of a 25\% RPS and its Impacts on Ratepayers' Electricity Bills}

For generating more electricity from renewable resources to achieve a $25 \%$ RPS, there will be a huge investment in renewable electricity projects to expand Michigan's current renewable energy capacity. Undoubtedly, to recover these extra capital investments, utilities will pass on costs to the electricity customers. To protect consumers from being charged too much more in electricity bills, the failed Proposal 3 required electricity providers not to increase the electricity rates by more than $1 \%$ in any year when complying with it. However, whether the $1 \%$ increase rate cap is achievable is uncertain. In the next section, the total cost of generating electricity from renewable resources to meet the $25 \%$ RPS requirement is estimated. After this, the impacts on the ratepayer's electricity bill under a 25\% RPS will be discussed.

\subsection{Projecting Future Renewable Electricity Generation}

According to EIA, the electricity demand will increase $24 \%, 27 \%$, and $17 \%$ for residential, commercial, and industrial sectors respectively from 2011 to 2040 in the U.S. (EIA 2013). After conversions, the annual increase in electricity sales for these three sectors are $0.72 \%, 0.80 \%, 0.52 \%{ }^{4}$. These national figures will be adopted to project the total electricity demand in Michigan from 2016 to 2025. The electricity demand of the transportation sector is excluded from the projection, because its electricity consumption

\footnotetext{
${ }^{4}$ Compounded Annual Growth Rate can be calculated by the following formula: $\mathrm{r}=\left(\mathrm{V}\left(\mathrm{t}_{0}\right) / \mathrm{V}\left(\mathrm{t}_{\mathrm{n}}\right)\right)^{\wedge}\left(\mathrm{t}_{\mathrm{n}}-\mathrm{t}_{0}\right)^{-1}-1 . \mathrm{V}\left(\mathrm{t}_{0}\right)$ and $\mathrm{V}\left(\mathrm{t}_{\mathrm{n}}\right)$ represent the start value and the finish value; $\mathrm{t}_{0}$ and $\mathrm{t}_{\mathrm{n}}$ represent the number of years.
} 
is far less than the other three sectors, which depend heavily on electricity. From EIA's state electricity profile, the electricity consumption in the transportation sector contributes little to the total electricity sales in Michigan ${ }^{5}$. Thus, it is reasonable to neglect its role in the total electricity use when projecting the State's future electricity demand. The 2011 data for electricity generation in Michigan is not available from EIA's states' electricity profiles. The annual electricity demand can be projected by using the above annual increase rates for different sectors and taking 2010 as the starting year for approximation. The projected electricity sales from 2016 to 2025 are presented in Table

\section{1.}

Table 2.1: Electricity Sales Projection from 2016 to 2025 in Michigan (Thousand MWh)

\begin{tabular}{|c|c|c|c|c|}
\hline Year & Residential & Commercial & Industrial & Total \\
\hline $\mathbf{2 0 1 6}$ & 36,206 & 39,990 & 31,816 & $\mathbf{1 0 8 , 0 1 2}$ \\
\hline $\mathbf{2 0 1 7}$ & 36,467 & 40,310 & 31,981 & $\mathbf{1 0 8 , 7 5 8}$ \\
\hline $\mathbf{2 0 1 8}$ & 36,730 & 40,632 & 32,148 & $\mathbf{1 0 9 , 5 1 0}$ \\
\hline $\mathbf{2 0 1 9}$ & 36,994 & 40,957 & 32,315 & $\mathbf{1 1 0 , 2 6 6}$ \\
\hline $\mathbf{2 0 2 0}$ & 37,261 & 41,285 & 32,483 & $\mathbf{1 1 1 , 0 2 8}$ \\
\hline $\mathbf{2 0 2 1}$ & 37,529 & 41,615 & 32,652 & $\mathbf{1 1 1 , 7 9 6}$ \\
\hline $\mathbf{2 0 2 2}$ & 37,799 & 41,948 & 32,821 & $\mathbf{1 1 2 , 5 6 9}$ \\
\hline $\mathbf{2 0 2 3}$ & 38,071 & 42,284 & 32,992 & $\mathbf{1 1 3 , 3 4 7}$ \\
\hline $\mathbf{2 0 2 4}$ & 38,345 & 42,622 & 33,164 & $\mathbf{1 1 4 , 1 3 1}$ \\
\hline $\mathbf{2 0 2 5}$ & 38,621 & 42,963 & 33,336 & $\mathbf{1 1 4 , 9 2 1}$ \\
\hline
\end{tabular}

Source: Author's calculations.

Based on MPSC's projections, the electricity providers are on track to fulfill the

${ }^{5}$ See "Table 8" on http://www.eia.gov/electricity/state/michigan. Retrieved on July 4, 2013. 
existing 10\% RES by 2015 (MPSC 2013). Moreover, the same report indicates that the contract prices of all renewable energy technologies except for two anaerobic digester contracts are less than the levelized cost of a coal-fired power plant. However, most of the current traditional coal and natural gas power plants can continue to be operated in the near future. If there is no new RPS/RES being mandated after 2015, there will be little incentive for utilities to accelerate the development of renewable energy. Although the MPSC assumed that the renewable electricity generated is expected to be increasing continuously after 2015, given uncertainty of how much renewable electricity will be generated, it is assumed that the $10 \%$ renewable electricity sales figure will not change in the subsequent years if there is no new RPS/RES mandated. In this case, the sales of renewable electricity, which are based on the $10 \%$ RES from 2016 to 2025, are projected as the status quo scenario. By the end of 2025, if $25 \%$ of electricity sales will be generated from renewable resources, the average annual increase in proportion of renewable electricity sales is $1.5 \%^{6}$ from 2016 to 2025 . Table 2.2 shows the projected renewable electricity sales under the status quo (10\% RES) as well as a $25 \%$ RPS scenario.

Here are some explanations about the figures in Table 2.1. The additional required renewable electricity sales equal the difference between the annual renewable electricity sales under the $25 \%$ RPS and $10 \%$ RES, which can be calculated by equation 1 :

$\mathbf{S}^{*}=\mathbf{S}_{25 \%} \mathbf{-} \mathbf{S}_{10} \%$

where: $\mathbf{S}^{*}=$ Additional Required Renewable Electricity Sales

${ }^{6}$ The $1.5 \%$ rate can be calculated by using the proportion of renewable electricity sales in 2025 minus the 2015 renewable electricity proportion, and then divide it by 10 years: $(25 \%-10 \%) / 10=1.5 \%$. 
Table 2.2: Required Renewable Electricity Sales in Michigan Under Different Scenarios (Thousand MWh)

\begin{tabular}{|c|c|c|c|c|c|c|}
\hline Year & $\begin{array}{c}\text { Total } \\
\text { Sales }\end{array}$ & $\begin{array}{c}\text { Annual } \\
\text { RPS } \\
\text { Target } \\
\mathbf{( 2 5 \%}\end{array}$ & $\begin{array}{c}\text { Required } \\
\text { Renewable } \\
\text { Electricity } \\
\text { Sales } \\
\mathbf{( 2 5 \%} \\
\text { RPS) }\end{array}$ & $\begin{array}{c}\text { Annual } \\
\text { RES } \\
\text { Target } \\
\mathbf{( 1 0 \%} \\
\text { RES) }\end{array}$ & $\begin{array}{c}\text { Required } \\
\text { Renewable } \\
\text { Electricity } \\
\text { Sales } \\
\mathbf{( 1 0 \%} \\
\text { RES) }\end{array}$ & $\begin{array}{c}\text { Additional } \\
\text { Required } \\
\text { Renewable } \\
\text { Electricity } \\
\text { Sales }\end{array}$ \\
\hline $\mathbf{2 0 1 6}$ & 108,012 & $11.50 \%$ & $12,421.40$ & $10 \%$ & $10,801.22$ & $1,620.18$ \\
\hline $\mathbf{2 0 1 7}$ & 108,758 & $13 \%$ & $14,138.57$ & $10 \%$ & $10,875.82$ & $3,262.75$ \\
\hline $\mathbf{2 0 1 8}$ & 109,510 & $14.50 \%$ & $15,878.89$ & $10 \%$ & $10,950.96$ & $4,927.93$ \\
\hline $\mathbf{2 0 1 9}$ & 110,266 & $16 \%$ & $17,642.60$ & $10 \%$ & $11,026.62$ & $6,615.97$ \\
\hline $\mathbf{2 0 2 0}$ & 111,028 & $17.50 \%$ & $19,429.95$ & $10 \%$ & $11,102.83$ & $8,327.12$ \\
\hline $\mathbf{2 0 2 1}$ & 111,796 & $19 \%$ & $21,241.20$ & $10 \%$ & $11,179.58$ & $10,061.62$ \\
\hline $\mathbf{2 0 2 2}$ & 112,569 & $20.50 \%$ & $23,076.58$ & $10 \%$ & $11,256.87$ & $11,819.71$ \\
\hline $\mathbf{2 0 2 3}$ & 113,347 & $22 \%$ & $24,936.36$ & $10 \%$ & $11,334.71$ & $13,601.65$ \\
\hline $\mathbf{2 0 2 4}$ & 114,131 & $23.50 \%$ & $26,820.79$ & $10 \%$ & $11,413.10$ & $15,407.69$ \\
\hline $\mathbf{2 0 2 5}$ & 114,921 & $25 \%$ & $28,730.14$ & $10 \%$ & $11,492.06$ & $17,238.08$ \\
\hline \multicolumn{7}{|c|}{} \\
\hline \multicolumn{7}{|c|}{}
\end{tabular}

Source: Author's calculations.

\section{$S_{25 \%}=$ Renewable Electricity Sales under a $25 \%$ RPS \\ $\mathrm{S}_{10 \%}=$ Renewable Electricity Sales under the 10\% RES}

To calculate the total cost of renewable electricity generation, the contribution of each type of renewable energy technology should be predetermined. According to the Michigan Renewable Energy Certification System (MRECS) ${ }^{7}$, from 2009 to 2012, most energy credits are generated from biomass, landfill gas, wind and hydroelectric

\footnotetext{
${ }^{7}$ According to the Michigan Renewable Energy Certification System (MIRECS) website, MRECS “issues, tracks, and enables retirement and trading of Michigan Renewable Energy Credits (RECs), Advanced Cleaner Energy (ACECs), and Michigan Incentive Renewable Energy Credits (ICs) under the state's Clean, Renewable and Efficient Energy Act". More information can be found at http://www.mirecs.org/. Retrieved on July 4, 2013.
} 
power (MPSC 2013). Since most of the potential sites have been tapped for hydroelectricity generation, which can be inferred from Table 1.1, the hydro proportion is excluded when calculating the additional new renewable electricity generation. While solar energy possesses less than $1 \%$ of total credits in the MRECS, solar energy is still regarded as an important renewable source to generate electricity. Thus, biomass, solar energy, landfill gas, and wind power are expected to be the most promising renewable energy sources to fulfill the utilities' yearly obligations in Michigan.

According to EIA's projection in the 2013 Annual Energy Outlook (AEO), from 2011 to 2040 , the average annual growth rate for electricity generated from biomass is $4.5 \%$ and $9.8 \%$ for electricity from solar energy among the non-hydropower renewable sources. Wind-power electric generation increases $2.6 \%$ per year. For landfill gas, there is no clear information about what its average growth rate is. However, from Figure 83 in the report, it seems that the electricity generated from landfill gas does not change over the projection period. Also according to MPSC (2013), the historical data from 2009 to 2012 show that landfill gas accounted for about $13 \%$ of the total renewable electricity generation in each year. Since the total electricity generation from this type of renewable energy fluctuated during these years ${ }^{8}$, and the development trend in the future cannot be derived precisely, an arbitrary 1\% increase rate from 2011 to 2040 is assigned to the electricity generation from landfill gas in Michigan.

Figure 2 summarizes all the renewable energy projects planned for Michigan based on contracts and solar energy programs approved by the MPSC through 2012.

\footnotetext{
${ }^{8}$ The electricity produced in Michigan from landfill gas was 664223.4MWh, 630194.9MWh, 683367.8MWh, 569216.3 MWh separately from 2009 to 2012.
} 


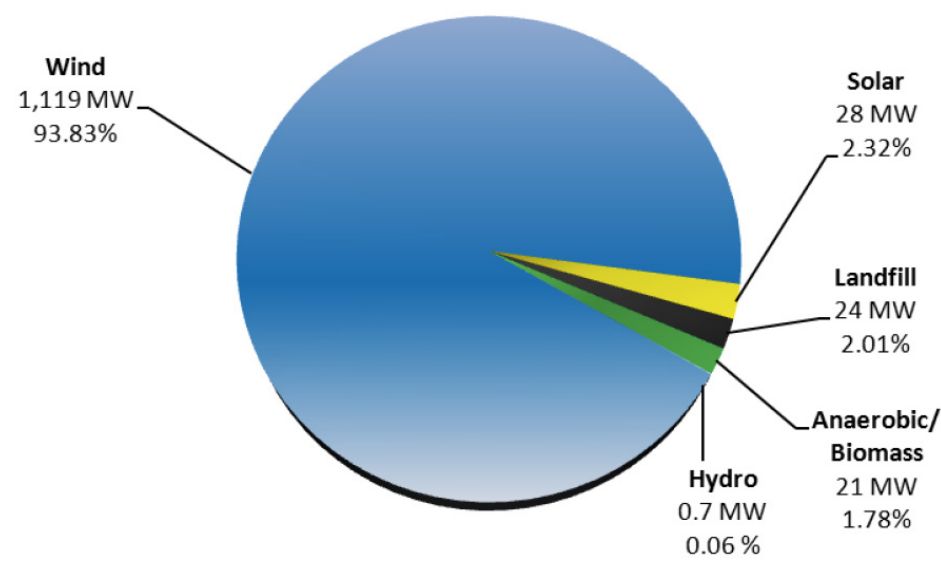

\section{Figure 2: Renewable Energy Capacity by Technology Type Approved by the MPSC through 2012 (MPSC 2013).}

Wind power provides $93.83 \%$ of the total renewable energy capacity based on the contracts. Given the dominant role of wind power, it is assumed that besides solar energy, biomass and landfill gas, the rest of required renewable electricity is only from wind power.

Based on Appendix E of MPSC (2013), one can infer the electricity generation from different kinds of renewable energies in $2012^{9}$. Using the data in 2012 as the starting point, future renewable electricity sales for different types of renewable energy sources can be projected based on the above assumptions for the $25 \%$ RPS scenario. The proportion of each renewable energy electricity sale is assumed to stay the same annually for the status quo. In this scenario, it is not surprising that the increased rate for the

\footnotetext{
${ }^{9}$ Based on the MIRECS, there were 4,378,587 total credits in 2012. The energy credits from solar energy, biomass and landfill gas represent less than $1 \%, 36 \%$ and $13 \%$ of the total energy credits separately. Additionally, one credit equals one KWh electricity generation. Assume that solar energy accounts for 1\% of the total credits. Thus, the electricity generation from the above three kinds of renewable energies are $43.78587,1576.29132,569.21631$ thousand MWh in 2012, respectively.
} 
electricity sales from individual renewable energy sources equals the increased rate of total renewable electricity sales. The projection results under the current $10 \%$ RES and a $25 \%$ RPS scenarios are provided in Tables $2.3-2.5$.

Table 2.3: The Renewable Electricity Sales Under the Current 10\% RES in Michigan (Thousand MWh)

\begin{tabular}{|c|c|c|c|c|c|c|}
\hline Year & Total & Solar & Biomass & $\begin{array}{c}\text { Landfill } \\
\text { Gas }\end{array}$ & Wind & $\begin{array}{c}\text { Increase } \\
\text { Rate }\end{array}$ \\
\hline $\mathbf{2 0 1 6}$ & $10,801.22$ & 58.36 & $1,811.23$ & 590.51 & $8,341.11$ & $0.69 \%$ \\
\hline $\mathbf{2 0 1 7}$ & $10,875.82$ & 58.77 & $1,823.74$ & 594.59 & $8,398.72$ & $0.69 \%$ \\
\hline $\mathbf{2 0 1 8}$ & $10,950.96$ & 59.17 & $1,836.34$ & 598.70 & $8,456.74$ & $0.69 \%$ \\
\hline $\mathbf{2 0 1 9}$ & $11,026.62$ & 59.58 & $1,849.03$ & 602.84 & $8,515.18$ & $0.69 \%$ \\
\hline $\mathbf{2 0 2 0}$ & $11,102.83$ & 59.99 & $1,861.81$ & 607.00 & $8,574.03$ & $0.69 \%$ \\
\hline $\mathbf{2 0 2 1}$ & $11,179.58$ & 60.41 & $1,874.68$ & 611.20 & $8,633.29$ & $0.69 \%$ \\
\hline $\mathbf{2 0 2 2}$ & $11,256.87$ & 60.82 & $1,887.64$ & 615.43 & $8,692.98$ & $0.69 \%$ \\
\hline $\mathbf{2 0 2 3}$ & $11,334.71$ & 61.24 & $1,900.69$ & 619.68 & $8,753.09$ & $0.69 \%$ \\
\hline $\mathbf{2 0 2 4}$ & $11,413.10$ & 61.67 & $1,913.84$ & 623.97 & $8,813.63$ & $0.69 \%$ \\
\hline $\mathbf{2 0 2 5}$ & $11,492.06$ & 62.09 & $1,927.08$ & 628.28 & $8,874.60$ & $0.69 \%$ \\
\hline
\end{tabular}

Source: Author's calculations.

The right three columns in Table 2.4 represent the annual increase rate of the energy generated from wind power among all the renewable electricity sales, and the proportion of the electricity sales generated from wind power among the total electricity sales, respectively. Since appropriate sites for wind power electric generation are limited, the available sites become restricted and the cost of expanding wind power capacity will increase after the least cost ones are exploited. The decreasing rate of electricity sales produced from wind power is in accordance with this fact. However, this was not taken into account when projecting the future renewable electricity sales. Computed by the results in Table 2.4, the average annual increase rate is $11.80 \%$ from 2016 to 2025, which 


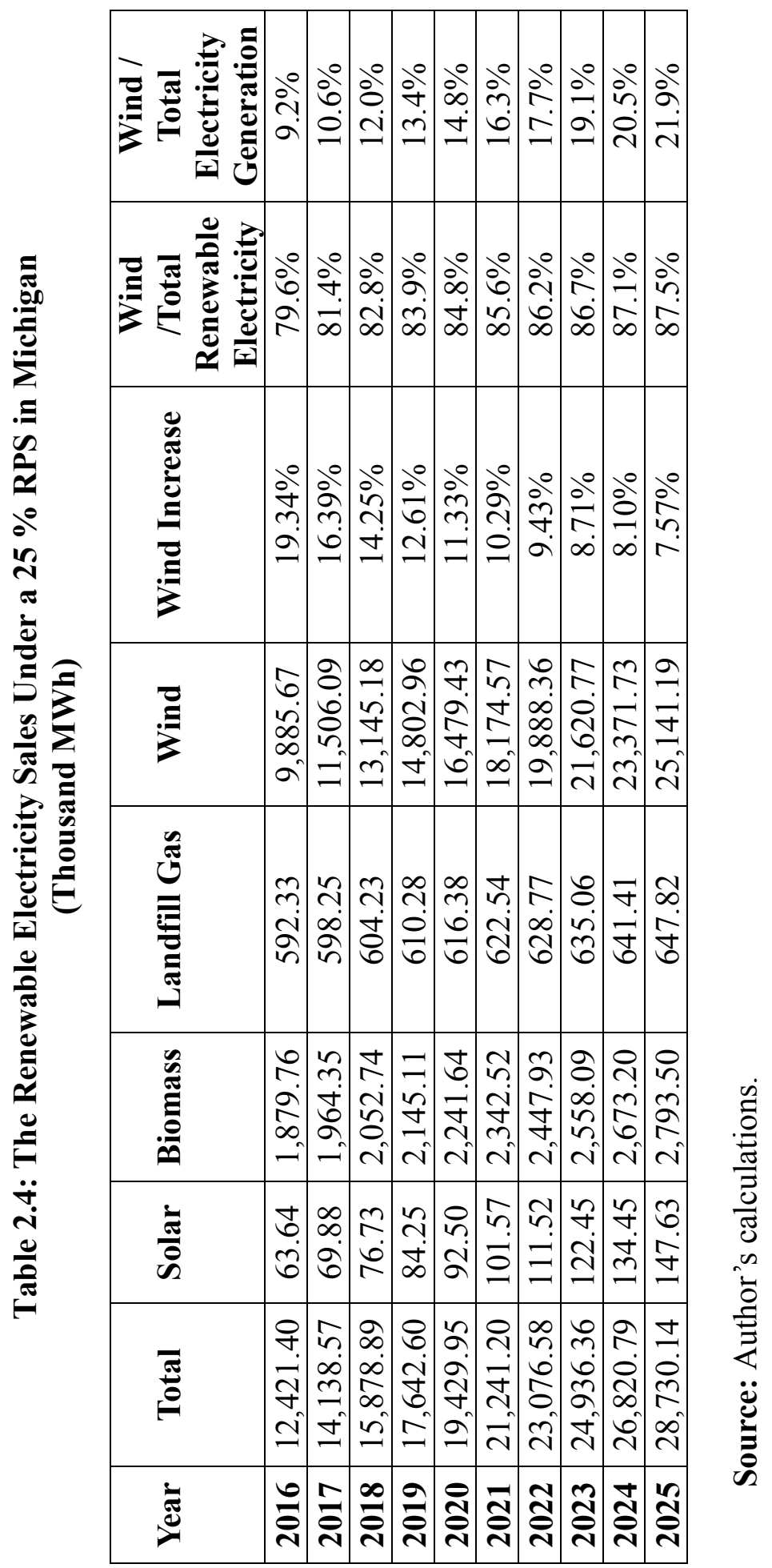


is much larger than EIA's estimate 2.6\% per year in the 2013 AEO. However, EIA's projection has a longer time span, which is from 2011 to 2040. If the future development of wind power generation is limited by less accessible sites, the decreasing trend for the growth rate of electricity from wind power will continue. Thus, it is possible that the average increase rate can be close to EIA's estimate when taking a longer period into account. Despite the fact that the growth rate is decreasing, the proportion of electricity sales generated from wind power is still increasing annually, which can be inferred from the right two columns in Table 2.4. In 2025, it will provide $87.5 \%$ of the total renewable electricity sales and $21.9 \%$ of the total electricity sales.

Subtracting the renewable electricity sales under the status quo from the sales under the $25 \%$ RPS, the additional required renewable electricity sales for different renewable technologies can be calculated. The results are shown in Table 2.5.

Table 2.5: Additional Required Renewable Electricity Sales due to a 25\% RPS in Michigan (Thousand MWh)

\begin{tabular}{|c|c|c|c|c|c|}
\hline Year & Total & Solar & Biomass & Landfill Gas & Wind \\
\hline $\mathbf{2 0 1 6}$ & $1,620.18$ & 5.28 & 68.52 & 1.81 & $1,544.56$ \\
\hline $\mathbf{2 0 1 7}$ & $3,262.75$ & 11.11 & 140.60 & 3.66 & $3,107.37$ \\
\hline $\mathbf{2 0 1 8}$ & $4,927.93$ & 17.56 & 216.40 & 5.53 & $4,688.44$ \\
\hline $\mathbf{2 0 1 9}$ & $6,615.97$ & 24.67 & 296.08 & 7.44 & $6,287.78$ \\
\hline $\mathbf{2 0 2 0}$ & $8,327.12$ & 32.51 & 379.84 & 9.38 & $7,905.40$ \\
\hline $\mathbf{2 0 2 1}$ & $10,061.62$ & 41.16 & 467.84 & 11.34 & $9,541.27$ \\
\hline $\mathbf{2 0 2 2}$ & $11,819.71$ & 50.70 & 560.29 & 13.34 & $11,195.38$ \\
\hline $\mathbf{2 0 2 3}$ & $13,601.65$ & 61.21 & 657.40 & 15.38 & $12,867.67$ \\
\hline $\mathbf{2 0 2 4}$ & $15,407.69$ & 72.78 & 759.36 & 17.44 & $14,558.10$ \\
\hline $\mathbf{2 0 2 5}$ & $17,238.08$ & 85.53 & 866.42 & 19.54 & $16,266.59$ \\
\hline
\end{tabular}

Source: Author's calculations. 


\subsection{The Cost of Renewable Electricity Generation Under a 25\% RPS}

Levelized Energy Cost (LEC) is widely used to estimate the total cost of generating electricity from various kinds of energy resources. According to EIA, LEC represents "the present value of the total cost of building and operating a generating plant over an assumed financial life and duty cycle, converted to equal annual payments and expressed in terms of real dollars to remove the impact of inflation" (EIA 2013). The LEC, which is estimated by EIA, includes overnight capital cost, fuel cost, fixed and variable operation and maintenance (O\&M) cost, and financing costs for specific technology based power plants. To incorporate all the aspects of electricity generation, total system LEC is adopted from EIA's 2013 AEO. Different from the basic LEC, total system LEC also includes transmission investment, which is a significant cost for the utilities to provide electricity. Thus, the total system LEC can be regarded as a close approximation, which includes almost all the cost during electric generation, to calculate

the total utilities' spending on supplying electricity. When determining the LECs for different technologies, one crucial assumption is that the electricity providers always find the least-cost technology or resources to build new electric generation capacity, or retrofit an existing power plant. Therefore, based on the 2013 AEO, solar PV and onshore wind power are selected as the potential technologies to help the utilities to fulfill the task of electricity generation.

According to the "Levelized Cost of New Generation Resources" section in the AEO from 2010 to 2013, the LCEs for the selected technologies are reproduced in Table 2.6. The costs of onshore wind power and solar PV have strongly decreasing trends based 
on EIA annual projections. Although the LECs of other types of the power plants may fluctuate in the projected years, all the LECs are trending downward as seen in Table 2.6. When calculating the total cost of renewable electricity generation under a $25 \%$ RPS, the LEC of the plant entering service in 2018, which is derived from EIA's 2013 AEO, represents the generation cost for the selected technology in each year from 2016 to 2020 .

Table 2.6: Levelized Cost of Power Plant for Different Technologies in the U.S. (2011\$/MWh)

\begin{tabular}{|c|c|c|c|c|}
\hline Year (Plant Entering Service) & $\mathbf{2 0 1 6}$ & $\mathbf{2 0 1 6}$ & $\mathbf{2 0 1 7}$ & $\mathbf{2 0 1 8}$ \\
\hline Conventional Coal & 104.54 & 99.11 & 100.53 & 100.1 \\
\hline Advanced Combined Cycle & 82.57 & 65.97 & 64.93 & 65.6 \\
\hline Biomass & 115.58 & 117.61 & 118.75 & 111 \\
\hline Wind-Onshore & 155.46 & 101.41 & 98.78 & 86.6 \\
\hline Solar PV & 412.45 & 220.28 & 157.13 & 114.3 \\
\hline
\end{tabular}

Sources: EIA (2010, 2011, 2012, 2013).

The 2013 AEO also presents LECs for new power plants in 2020 and 2040, which is shown in Figure 3. LECs from 2021 to 2025 can be approximated in the following way: from Figure 3, the annual LECs of new coal and wind power plants decrease about 0.09 and 0.06 cents $/ \mathrm{kWh}$. Differing from other technologies, the cost of a natural gas combined cycle plant has an increasing trend from 2020 to 2040 . The annual increase rate is about 0.08 cents $/ \mathrm{kWh} .{ }^{10}$ No information is available for the cost of biomass and solar energy power plants in this report. For approximation, it is assumed that the LEC of a biomass power plant has the same annual decreasing cost as the LEC of a coal-fire

\footnotetext{
10 The annual cost change can be approximated in the following way: For coal: $(10.3-12.1) / 20=-0.09$, for wind: $(7.5-8.6) / 20=-0.055$, for natural gas: $(8.4-6.8) / 20=0.08$.
} 


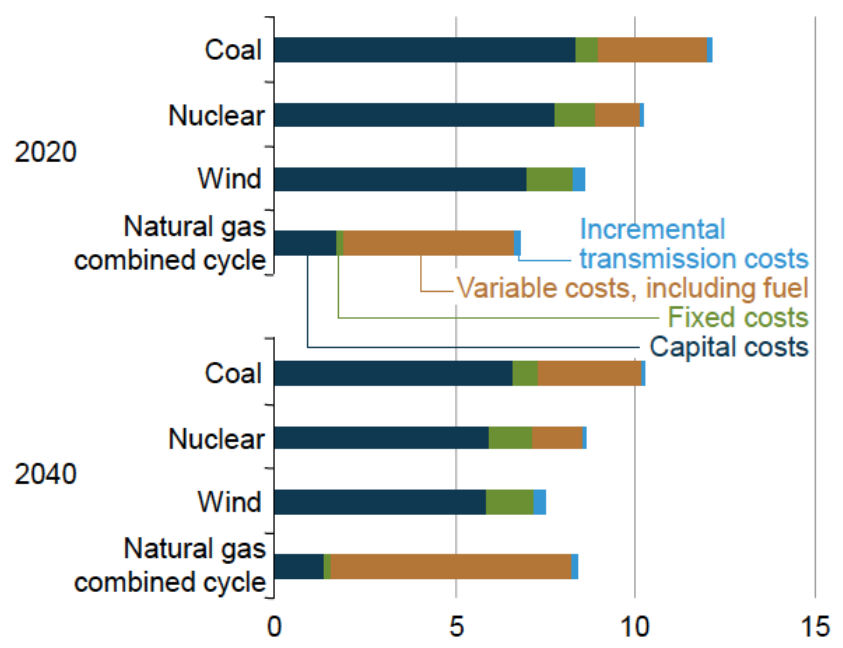

Figure 3: LEC for New Power Plants (Excluding Subsidies) in 2020 and 2040 in the U.S. (2011 Cents/KWh) (EIA 2013).

power plant. Similarly, the LEC of a solar power plant is assumed to decrease at the same rate as an electric plant powered by wind. Thus, the LECs of solar energy and biomass power plants are assumed to decrease 0.04 and 0.1 cents $/ \mathrm{kWh}$ annually.

The LEC for electricity generated from landfill gas is not available from the 2013 AEO. However, one can infer this kind of information from Sustainable Energy in America 2013 Factbook (BCSE 2013). The LEC for landfill gas falls in the range from $\$ 47$ to \$94/MWh, with the median figure $\$ 59 / \mathrm{MWh}(2012 \$)$ in 2012 . To estimate the LEC for landfill gas power plant that will enter service in 2018, it is assumed that the change of its LEC is in accordance with the change in LEC of a biomass plant. After the adjustment ${ }^{11}$,

${ }^{11}$ The LEC of a landfill gas power plant that will enter service in 2018 can be approximated as follows: From BCSE 2013, the current mid LEC value of biomass gasification power plant is about $\$ 128 / \mathrm{MWh}$ (2012\$) in 2012. The average figure for the LEC of biomass power plant that will enter service in 2018 is $\$ 109.8 / \mathrm{MWh}$ (2011\$) from the $2013 \mathrm{AEO}$. Thus, the median figure for the LEC of landfill gas plant can be estimated by the following equation: $(59 / 128) * 109.8=\$ 50.6 / \mathrm{MWh}(2011 \$)$. If the minimum and maximum figure is changed by the same scale as the average figure, the lower and upper LEC ranges of landfill gas plant that will enter service in 2018 are $\$ 40.3 / \mathrm{MWh}(=(47 / 128) * 109.80)$ and $\$ 80.6 / \mathrm{MWh}$ $(=(94 / 128) * 109.8)(2011 \$)$. 
the average LEC of a landfill gas plant that will enter service in 2018 is $\$ 50.6 / \mathrm{MWh}$, with the range $\$ 40.3$ - \$80.6/MWh (2011\$). The LEC from BSCE (2013) only includes the costs of equipment, capital, and operation. Thus, $\$ 1.2 / \mathrm{MWh}$ is added to reflect the transmission investment. Ultimately, the total system LEC for a landfill gas power plant entering service in 2018 falls in the range $\$ 41.5$ - $\$ 81.8 / \mathrm{MWh}$, with the average figure $\$ 51.8 / \mathrm{MWh}$. These figures can be used to calculate the cost of electricity generation from landfill gas from 2016 to 2020 . The annual decreased cost of biomass power $(0.09$ cent $/ \mathrm{kWh}$ ) is applied to LEC of landfill gas plant after 2020. Integrating all the above information, the annual average LECs for the selected renewable energy power plants, which are regarded as the best estimates, are shown in Table 2.7. To make a comparison, Table 2.7 includes the LECs of power plants powered by fossil fuels and renewable energy sources. The minimum and maximum LECs can be found in the Appendix of this thesis.

Table 2.7: The Best Estimate of LECs of Power Plants in the U.S. (2011\$/MWh)

\begin{tabular}{|c|c|c|c|c|c|c|}
\hline Year & $\begin{array}{c}\text { Conventional } \\
\text { Coal }\end{array}$ & $\begin{array}{c}\text { Natural Gas-fired } \\
\text { (Advanced } \\
\text { Combined Cycle) }\end{array}$ & $\begin{array}{c}\text { Solar } \\
\text { PV }\end{array}$ & Biomass & $\begin{array}{c}\text { Landfill } \\
\text { Gas }\end{array}$ & $\begin{array}{c}\text { Wind } \\
\text { (Onshore) }\end{array}$ \\
\hline $\mathbf{2 0 1 6}$ & 100.1 & 65.6 & 144.3 & 111 & 51.8 & 86.6 \\
\hline $\mathbf{2 0 1 7}$ & 100.1 & 65.6 & 144.3 & 111 & 51.8 & 86.6 \\
\hline $\mathbf{2 0 1 8}$ & 100.1 & 65.6 & 144.3 & 111 & 51.8 & 86.6 \\
\hline $\mathbf{2 0 1 9}$ & 100.1 & 65.6 & 144.3 & 111 & 51.8 & 86.6 \\
\hline $\mathbf{2 0 2 0}$ & 100.1 & 65.6 & 144.3 & 111 & 51.8 & 86.6 \\
\hline $\mathbf{2 0 2 1}$ & 99.2 & 66.4 & 143.7 & 110.1 & 50.9 & 86 \\
\hline $\mathbf{2 0 2 2}$ & 98.3 & 67.2 & 143.1 & 109.2 & 50 & 85.4 \\
\hline $\mathbf{2 0 2 3}$ & 97.4 & 68 & 142.5 & 108.3 & 49.1 & 84.8 \\
\hline $\mathbf{2 0 2 4}$ & 96.5 & 68.8 & 141.9 & 107.4 & 48.2 & 84.2 \\
\hline $\mathbf{2 0 2 5}$ & 95.6 & 69.6 & 141.3 & 106.5 & 47.3 & 83.6 \\
\hline
\end{tabular}

Sources: EIA(2013) and BSCE (2013). 
The total amount of electricity generation is more than the amount that is transmitted to the customers. According to EIA ${ }^{12}$, the annual average electricity losses during transmission and distribution are about $7 \%$ in the U.S. Also, to calculate the additional electricity generation, the capacity factor for different electricity generation technologies should be considered. The capacity factor of a power plant represents the ratio of the actual output of a power plant to its nameplate capacity, which represents the planned technical full-load sustained output of the power plant. The total electricity generation can be calculated by equation 2 :

$\mathbf{G}=\frac{S}{(1-X) * K}$

where: $\mathbf{G}=$ Total Electricity Generation

$\mathbf{S}=$ Total Electricity Generation

X = Electricity Loss Rate

$K=$ Capacity Factor

Recall that the additional required renewable electricity sales equal the difference between the renewable electricity sales under a 25\% RPS and 10\% RES, which is shown in Table 2.5. Applying the figures in Table 2.5 into the above formula, the additional required renewable electricity generation under different scenarios can be calculated. The results are presented in Table 2.8. In the same way, the total renewable electricity generation under the current 10\% RES and a 25\% RPS can be calculated by using the figures in Table 2.3 - 2.4. The results are shown in Table $2.9-2.10$.

Using the data in Table 2.7 and 2.8, the additional cost of generating the required

12 See http://www.eia.gov/tools/faqs/faq.cfm?id=105\&t=3. Retrieved on July 4, 2013. 
Table 2.8: Additional Required Renewable Electricity Generation due to a 25\% RPS in Michigan (Thousand MWh)

\begin{tabular}{|c|c|c|c|c|c|}
\hline Year & Total & Solar PV & Biomass & Landfill Gas & Wind (Onshore) \\
\hline $\mathbf{2 0 1 6}$ & $\mathbf{4 , 9 9 8 . 6 9}$ & 22.71 & 88.77 & 2.44 & $4,884.77$ \\
\hline $\mathbf{2 0 1 7}$ & $\mathbf{1 0 , 0 6 2 . 1 0}$ & 47.80 & 182.15 & 4.92 & $9,827.23$ \\
\hline $\mathbf{2 0 1 8}$ & $\mathbf{1 5 , 1 9 0 . 7 5}$ & 75.51 & 280.35 & 7.44 & $14,827.45$ \\
\hline $\mathbf{2 0 1 9}$ & $\mathbf{2 0 , 3 8 5 . 1 4}$ & 106.09 & 383.58 & 10.00 & $19,885.47$ \\
\hline $\mathbf{2 0 2 0}$ & $\mathbf{2 5 , 6 4 5 . 7 8}$ & 139.83 & 492.08 & 12.60 & $25,001.27$ \\
\hline $\mathbf{2 0 2 1}$ & $\mathbf{3 0 , 9 7 3 . 1 8}$ & 177.04 & 606.09 & 15.25 & $30,174.81$ \\
\hline $\mathbf{2 0 2 2}$ & $\mathbf{3 6 , 3 6 7 . 8 5}$ & 218.05 & 725.86 & 17.94 & $35,406.00$ \\
\hline $\mathbf{2 0 2 3}$ & $\mathbf{4 1 , 8 3 0 . 3 1}$ & 263.25 & 851.66 & 20.67 & $40,694.73$ \\
\hline $\mathbf{2 0 2 4}$ & $\mathbf{4 7 , 3 6 1 . 0 5}$ & 313.04 & 983.76 & 23.44 & $46,040.81$ \\
\hline $\mathbf{2 0 2 5}$ & $\mathbf{5 2 , 9 6 0 . 5 9}$ & 367.88 & $1,122.45$ & 26.26 & $51,444.00$ \\
\hline $\begin{array}{c}\text { Capacity } \\
\text { Factor }\end{array}$ & N/A & 0.25 & 0.83 & 0.80 & 0.34 \\
\hline $\begin{array}{c}\text { Electricity } \\
\text { Loss Rate }\end{array}$ & $7 \%$ & $7 \%$ & $7 \%$ & $7 \%$ & $7 \%$ \\
\hline
\end{tabular}

Source: Author's calculations.

Table 2.9: Total Renewable Electricity Generation Under a 25\% RPS in Michigan (Thousand MWh)

\begin{tabular}{|c|c|c|c|c|c|}
\hline Year & Total & Solar PV & Biomass & Landfill Gas & Wind (Onshore) \\
\hline $\mathbf{2 0 1 6}$ & $\mathbf{3 4 , 7 6 9 . 0 9}$ & 273.73 & $2,435.23$ & 796.14 & $31,263.99$ \\
\hline $\mathbf{2 0 1 7}$ & $\mathbf{4 0 , 0 3 8 . 1 3}$ & 300.55 & $2,544.82$ & 804.10 & $36,388.65$ \\
\hline $\mathbf{2 0 1 8}$ & $\mathbf{4 5 , 3 7 3 . 8 6}$ & 330.01 & $2,659.34$ & 812.14 & $41,572.37$ \\
\hline $\mathbf{2 0 1 9}$ & $\mathbf{5 0 , 7 7 6 . 8 1}$ & 362.35 & $2,779.01$ & 820.26 & $46,815.19$ \\
\hline $\mathbf{2 0 2 0}$ & $\mathbf{5 6 , 2 4 7 . 4 9}$ & 397.86 & $2,904.06$ & 828.47 & $52,117.10$ \\
\hline $\mathbf{2 0 2 1}$ & $\mathbf{6 1 , 7 8 6 . 4 2}$ & 436.85 & $3,034.74$ & 836.75 & $57,478.07$ \\
\hline $\mathbf{2 0 2 2}$ & $\mathbf{6 7 , 3 9 4 . 1 2}$ & 479.66 & $3,171.31$ & 845.12 & $62,898.03$ \\
\hline $\mathbf{2 0 2 3}$ & $\mathbf{7 3 , 0 7 1 . 1 2}$ & 526.67 & $3,314.02$ & 853.57 & $68,376.87$ \\
\hline $\mathbf{2 0 2 4}$ & $\mathbf{7 8 , 8 1 7 . 9 4}$ & 578.28 & $3,463.15$ & 862.11 & $73,914.40$ \\
\hline $\mathbf{2 0 2 5}$ & $\mathbf{8 4 , 6 3 5 . 0 8}$ & 634.95 & $3,618.99$ & 870.73 & $79,510.41$ \\
\hline $\begin{array}{c}\text { Capacity } \\
\text { Factor }\end{array}$ & N/A & 0.25 & 0.83 & 0.80 & 0.34 \\
\hline $\begin{array}{c}\text { Electricity } \\
\text { Loss Rate }\end{array}$ & $7 \%$ & $7 \%$ & $7 \%$ & $7 \%$ & $7 \%$ \\
\hline
\end{tabular}

Source: Author's calculations. 
Table 2.10: Total Renewable Electricity Generation Under the Current 10\% RES in Michigan (Thousand MWh)

\begin{tabular}{|c|c|c|c|c|c|}
\hline Year & Total & Solar PV & Biomass & Landfill Gas & Wind (Onshore) \\
\hline $\mathbf{2 0 1 6}$ & $\mathbf{2 9 , 7 7 0 . 4 0}$ & 251.02 & $2,346.46$ & 793.70 & $26,379.22$ \\
\hline $\mathbf{2 0 1 7}$ & $\mathbf{2 9 , 9 7 6 . 0 3}$ & 252.75 & $2,362.67$ & 799.18 & $26,561.42$ \\
\hline $\mathbf{2 0 1 8}$ & $\mathbf{3 0 , 1 8 3 . 1 1}$ & 254.50 & $2,378.99$ & 804.70 & $26,744.92$ \\
\hline $\mathbf{2 0 1 9}$ & $\mathbf{3 0 , 3 9 1 . 6 7}$ & 256.26 & $2,395.43$ & 810.27 & $26,929.72$ \\
\hline $\mathbf{2 0 2 0}$ & $\mathbf{3 0 , 6 0 1 . 7 1}$ & 258.03 & $2,411.98$ & 815.87 & $27,115.83$ \\
\hline $\mathbf{2 0 2 1}$ & $\mathbf{3 0 , 8 1 3 . 2 4}$ & 259.81 & $2,428.65$ & 821.50 & $27,303.27$ \\
\hline $\mathbf{2 0 2 2}$ & $\mathbf{3 1 , 0 2 6 . 2 7}$ & 261.61 & $2,445.45$ & 827.18 & $27,492.03$ \\
\hline $\mathbf{2 0 2 3}$ & $\mathbf{3 1 , 2 4 0 . 8 2}$ & 263.42 & $2,462.36$ & 832.90 & $27,682.14$ \\
\hline $\mathbf{2 0 2 4}$ & $\mathbf{3 1 , 4 5 6 . 8 9}$ & 265.24 & $2,479.39$ & 838.66 & $27,873.60$ \\
\hline $\mathbf{2 0 2 5}$ & $\mathbf{3 1 , 6 7 4 . 4 9}$ & 267.07 & $2,496.54$ & 844.47 & $28,066.41$ \\
\hline $\begin{array}{c}\text { Capacity } \\
\text { Factor }\end{array}$ & N/A & 0.25 & 0.83 & 0.80 & 0.34 \\
\hline $\begin{array}{c}\text { Electricity } \\
\text { Loss Rate }\end{array}$ & $\mathbf{7 \%} \%$ & $7 \%$ & $7 \%$ & $7 \%$ & $7 \%$ \\
\hline
\end{tabular}

Source: Author's calculations.

Table 2.11: The Best Estimate for the Additional Cost of Renewable Electricity Generation Under a 25\% RPS in Michigan (Million 2011\$)

\begin{tabular}{|c|c|c|c|c|c|}
\hline Year & Total & Solar PV & Biomass & Landfill Gas & Wind (Onshore) \\
\hline $\mathbf{2 0 1 6}$ & $\mathbf{4 3 6 . 2 8}$ & 3.28 & 9.85 & 0.13 & 423.02 \\
\hline $\mathbf{2 0 1 7}$ & $\mathbf{8 7 8 . 4 1}$ & 6.90 & 20.22 & 0.25 & 851.04 \\
\hline $\mathbf{2 0 1 8}$ & $\mathbf{1 , 3 2 6 . 4 6}$ & 10.90 & 31.12 & 0.39 & $1,284.06$ \\
\hline $\mathbf{2 0 1 9}$ & $\mathbf{1 , 7 8 0 . 4 9}$ & 15.31 & 42.58 & 0.52 & $1,722.08$ \\
\hline $\mathbf{2 0 2 0}$ & $\mathbf{2 , 2 4 0 . 5 6}$ & 20.18 & 54.62 & 0.65 & $2,165.11$ \\
\hline $\mathbf{2 0 2 1}$ & $\mathbf{2 , 6 8 7 . 9 8}$ & 25.44 & 66.73 & 0.78 & $2,595.03$ \\
\hline $\mathbf{2 0 2 2}$ & $\mathbf{3 , 1 3 5 . 0 4}$ & 31.20 & 79.26 & 0.90 & $3,023.67$ \\
\hline $\mathbf{2 0 2 3}$ & $\mathbf{3 , 5 8 1 . 6 8}$ & 37.51 & 92.23 & 1.01 & $3,450.91$ \\
\hline $\mathbf{2 0 2 4}$ & $\mathbf{4 , 0 2 7 . 8 4}$ & 44.42 & 105.66 & 1.13 & $3,876.64$ \\
\hline $\mathbf{2 0 2 5}$ & $\mathbf{4 , 4 7 3 . 4 8}$ & 51.98 & 119.54 & 1.24 & $4,300.72$ \\
\hline
\end{tabular}

Source: Author's calculations. 
Table 2.12: The Best Estimate for the Cost of Renewable Electricity Generation Under a 25\% RPS in Michigan (Million 2011\$)

\begin{tabular}{|c|c|c|c|c|c|}
\hline Year & Total & Solar PV & Biomass & Landfill Gas & Wind (Onshore) \\
\hline $\mathbf{2 0 1 6}$ & $\mathbf{3 , 0 5 8 . 5 1}$ & 39.50 & 270.31 & 41.24 & $2,707.46$ \\
\hline $\mathbf{2 0 1 7}$ & $\mathbf{3 , 5 1 8 . 7 5}$ & 43.37 & 282.47 & 41.65 & $3,151.26$ \\
\hline $\mathbf{2 0 1 8}$ & $\mathbf{3 , 9 8 5 . 0 4}$ & 47.62 & 295.19 & 42.07 & $3,600.17$ \\
\hline $\mathbf{2 0 1 9}$ & $\mathbf{4 , 4 5 7 . 4 4}$ & 52.29 & 308.47 & 42.49 & $4,054.20$ \\
\hline $\mathbf{2 0 2 0}$ & $\mathbf{4 , 9 3 6 . 0 2}$ & 57.41 & 322.35 & 42.91 & $4,513.34$ \\
\hline $\mathbf{2 0 2 1}$ & $\mathbf{5 , 3 8 2 . 6 1}$ & 62.78 & 334.13 & 42.59 & $4,943.11$ \\
\hline $\mathbf{2 0 2 2}$ & $\mathbf{5 , 8 2 8 . 6 9}$ & 68.64 & 346.31 & 42.26 & $5,371.49$ \\
\hline $\mathbf{2 0 2 3}$ & $\mathbf{6 , 2 7 4 . 2 3}$ & 75.05 & 358.91 & 41.91 & $5,798.36$ \\
\hline $\mathbf{2 0 2 4}$ & $\mathbf{6 , 7 1 9 . 1 5}$ & 82.06 & 371.94 & 41.55 & $6,223.59$ \\
\hline $\mathbf{2 0 2 5}$ & $\mathbf{7 , 1 6 3 . 4 0}$ & 89.72 & 385.42 & 41.19 & $6,647.07$ \\
\hline
\end{tabular}

Source: Author's calculations.

Table 2.13: The Best Estimate for the Cost of Renewable Electricity Generation Under the Current 10\% RES in Michigan (Million 2011\$)

\begin{tabular}{|c|c|c|c|c|c|}
\hline Year & Total & Solar PV & Biomass & Landfill Gas & Wind (Onshore) \\
\hline $\mathbf{2 0 1 6}$ & $\mathbf{2 , 6 2 2 . 2 3}$ & 36.22 & 260.46 & 41.11 & $2,284.44$ \\
\hline $\mathbf{2 0 1 7}$ & $\mathbf{2 , 6 4 0 . 3 5}$ & 36.47 & 262.26 & 41.40 & $2,300.22$ \\
\hline $\mathbf{2 0 1 8}$ & $\mathbf{2 , 6 5 8 . 5 9}$ & 36.72 & 264.07 & 41.68 & $2,316.11$ \\
\hline $\mathbf{2 0 1 9}$ & $\mathbf{2 , 6 7 6 . 9 6}$ & 36.98 & 265.89 & 41.97 & $2,332.11$ \\
\hline $\mathbf{2 0 2 0}$ & $\mathbf{2 , 6 9 5 . 4 6}$ & 37.23 & 267.73 & 42.26 & $2,348.23$ \\
\hline $\mathbf{2 0 2 1}$ & $\mathbf{2 , 6 9 4 . 6 3}$ & 37.34 & 267.39 & 41.81 & $2,348.08$ \\
\hline $\mathbf{2 0 2 2}$ & $\mathbf{2 , 6 9 3 . 6 6}$ & 37.44 & 267.04 & 41.36 & $2,347.82$ \\
\hline $\mathbf{2 0 2 3}$ & $\mathbf{2 , 6 9 2 . 5 5}$ & 37.54 & 266.67 & 40.90 & $2,347.45$ \\
\hline $\mathbf{2 0 2 4}$ & $\mathbf{2 , 6 9 1 . 3 0}$ & 37.64 & 266.29 & 40.42 & $2,346.96$ \\
\hline $\mathbf{2 0 2 5}$ & $\mathbf{2 , 6 8 9 . 9 1}$ & 37.74 & 265.88 & 39.94 & $2,346.35$ \\
\hline
\end{tabular}

Source: Author's calculations. 
amount of renewable electricity due to a $25 \%$ RPS can be easily computed by multiplying the figures in these two tables accordingly. The average cost is regarded as the best estimate, which is presented in Table 2.11. The total cost of renewable electricity generation under a $25 \%$ RPS and the current $10 \%$ RES can be computed similarly. The best estimates for these two scenarios are shown in Table $2.12-2.13$. The lower and upper ranges for these two scenarios can be found in the Appendix of this thesis.

To calculate the cost of a $25 \%$ RPS in present value terms, all the costs should be discounted to the present by equation 3 :

$P V C=\sum_{t=0}^{t} C_{t}(1+r)^{-t}$

where: PVC $=$ Present Value of Total Costs

$$
\begin{aligned}
& C_{t}=\text { Cost in Year } t \\
& r=\text { Discount Rate }
\end{aligned}
$$

Using a discount rate to discount the future values accounts for the fact that people have a time preference when they consider money in the future. It is true that a dollar received today is more valuable than the one received in the future. Considering the inflation factor, the real interest rate is adopted as the appropriate discount rate in the thesis. In 2013, the real interest rate of a 10 -year investment is $0.1 \%$ (OMB 2012). After the conversion, the best estimate for the present additional total cost of renewable electricity generation under a $25 \%$ RPS is $\$ 24.35$ billion from 2016 to 2025 , with a range from \$20.61 to 28.24 billion. More details for the lower and upper cost ranges are shown in the Appendix of this thesis. 


\subsection{Tax Credit Effect}

The federal production tax credit (PTC) for renewable electricity generation is a per-kilowatt-hour tax credit for electricity generated by qualified renewable energy resources. It can be sold by the taxpayer to an unrelated person during the taxable year ${ }^{13}$. The PTC, which was originally enacted in 1992, has been renewed many times and the current PTC was extended through 2013 by the American Taxpayer Relief Act of 2012 (H.R. 6, Sec. 407) in January $2013^{14}$. When calculating the total system LECs for different kinds of renewable energy power plants in the previous sections, tax credits were excluded from the analysis. According to the current tax policy, if renewable electricity generation projects can be constructed by the end of 2013, the PTCs for different renewable electricity production technologies are shown in Table 2.14.

\section{Table 2.14: Current Production Tax Credits for Different Renewable Electricity Production Technologies in the U.S. (Cents/kWh)}

\begin{tabular}{|c|c|}
\hline Resource Type & Credit Amount \\
\hline Wind & 2.3 \\
\hline Closed-Loop Biomass & 2.3 \\
\hline Open-Loop Biomass & 1.1 \\
\hline Landfill Gas & 1.1 \\
\hline
\end{tabular}

Source: DSIRE (2013).

Under the current law, solar thermal and PV plants can receive 30\% Investment Tax Credits (ITCs) if entering service by the end of 2016, which can be used to reduce

\footnotetext{
${ }^{13}$ More information about PTC for renewable energy can be found at the DSIRE at http://dsireusa.org/incentives/incentive.cfm?Incentive_Code=US13F. Retrieved on July 4, 2013.

${ }^{14}$ See http://www.gpo.gov/fdsys/pkg/BILLS-112hr8eas/pdf/BILLS-112hr8eas.pdf. Retrieved on July 4, 2013.
} 
tax liability for the plant owners. After 2016, however, new solar plants can receive only $10 \%$ ITCs $^{15}$. Given the uncertainty of the future tax credit policies, supposing that the PTCs for the wind, biomass and landfill gas power plants will last and not change until 2025 or thereafter, the annual Tax Credits (TCs) earned by different renewable electricity plants are shown in Table 2.15 by multiplying the figures in Table 2.14 by the total renewable electricity generation in Table 2.9. Table 2.16 presents the best estimate for the total cost of renewable electricity technologies under a 25\% RPS when TCs are included.

Table 2.15: Best Estimate for the Total Tax Credits Earned by Different Renewable Electricity Power Plants Under a 25\% RPS in Michigan (Million 2011\$)

\begin{tabular}{|c|c|c|c|c|}
\hline Year & $\begin{array}{c}\text { Solar } \\
\text { PV }^{\mathbf{1 6}}\end{array}$ & Biomass $^{\mathbf{1 7}}$ & Landfill Gas & Wind (Onshore) \\
\hline $\mathbf{2 0 1 6}$ & 11.85 & 41.40 & 8.76 & 719.07 \\
\hline $\mathbf{2 0 1 7}$ & 4.34 & 43.26 & 8.85 & 836.94 \\
\hline $\mathbf{2 0 1 8}$ & 4.76 & 45.21 & 8.93 & 956.16 \\
\hline $\mathbf{2 0 1 9}$ & 5.23 & 47.24 & 9.02 & $1,076.75$ \\
\hline $\mathbf{2 0 2 0}$ & 5.74 & 49.37 & 9.11 & $1,198.69$ \\
\hline $\mathbf{2 0 2 1}$ & 6.28 & 51.59 & 9.20 & $1,322.00$ \\
\hline $\mathbf{2 0 2 2}$ & 6.86 & 53.91 & 9.30 & $1,446.65$ \\
\hline $\mathbf{2 0 2 3}$ & 7.51 & 56.34 & 9.39 & $1,572.67$ \\
\hline $\mathbf{2 0 2 4}$ & 8.21 & 58.87 & 9.48 & $1,700.03$ \\
\hline $\mathbf{2 0 2 5}$ & 8.97 & 61.52 & 9.58 & $1,828.74$ \\
\hline
\end{tabular}

Source: Author's calculations.

${ }^{15}$ See the "Note" under Table 1 in "Levelized Cost of New Generation Resources in the Annual Energy Outlook 2013". (EIA 2013) Retrieved from:

http://www.eia.gov/forecasts/aeo/er/electricity_generation.cfm on July 4, 2013.

${ }^{16}$ In 2016, the solar plant can receive 30\% ITC and after 2016 10\% ITC will be applied. Multiplying these figures with the best estimate for LECs of solar PV under 25\% RPS in Table 2.12, the tax credits for sola PV power plant can be calculated. The figures in this column reflect the total TCs for solar PV.

${ }^{17}$ The value of PTC for Biomass in the calculation is 1.7 cents/ KWh, which is the average value of the PTCs for Closed-Loop and Open-Loop Biomass technologies. 
Table 2.16: The Best Estimate for the Cost of Renewable Electricity Power Plants Under a 25\% RPS in Tax Credits Included Scenario (Million 2011 \$)

\begin{tabular}{|c|c|c|}
\hline Year & TC not Included & TC Included \\
\hline $\mathbf{2 0 1 6}$ & $3,058.51$ & $2,277.43$ \\
\hline $\mathbf{2 0 1 7}$ & $3,518.75$ & $2,625.37$ \\
\hline $\mathbf{2 0 1 8}$ & $3,985.04$ & $2,969.97$ \\
\hline $\mathbf{2 0 1 9}$ & $4,457.44$ & $3,319.20$ \\
\hline $\mathbf{2 0 2 0}$ & $4,936.02$ & $3,673.10$ \\
\hline $\mathbf{2 0 2 1}$ & $5,382.61$ & $3,993.54$ \\
\hline $\mathbf{2 0 2 2}$ & $5,828.69$ & $4,311.97$ \\
\hline $\mathbf{2 0 2 3}$ & $6,274.23$ & $4,628.33$ \\
\hline $\mathbf{2 0 2 4}$ & $6,719.15$ & $4,942.55$ \\
\hline $\mathbf{2 0 2 5}$ & $7,163.40$ & $5,254.58$ \\
\hline
\end{tabular}

Source: Author's calculations.

The figures in this table are the results from subtracting the TCs in Table 2.15 from total system LECs in Table 2.12. Still, the average estimate is regarded as the best estimate. The lower and upper ranges are shown in the Appendix of the thesis.

Based on the information in Table 2.11 and 2.15 , the additional renewable electricity generation cost due to a $25 \%$ RPS, if all the TCs are included, is shown in Table 2.17 and lower and upper ranges can be found in the Appendix of the thesis. Based on the results in Table 2.17, the present value of the additional cost due to a $25 \%$ RPS in this scenario is $\$ 17.88$ billion, with a range from $\$ 14.15$ billion to $\$ 21.76$ billion. The best estimate is about $\$ 7$ billion lower than the best estimate for the present value of additional renewable electricity generation cost without TCs effects ( $\$ 24.35$ billion). The present value of the total cost of renewable electric power plants under a $25 \%$ RPS in the TCs included scenario is $\$ 37.69$ billion, with a range from $\$ 29.94$ billion to $\$ 46.03$ billion. 
Table 2.17: The Best Estimate for the Additional Cost of Renewable Electricity Generation due to a 25\% RPS in Michigan in Tax Credits Included Scenario (Million 2011\$)

\begin{tabular}{|l|c|c|c|}
\hline Year & $\begin{array}{c}\text { Additional Cost } \\
\text { Without TCs }\end{array}$ & Total TCs & $\begin{array}{c}\text { Additional Cost } \\
\text { Including TCs }\end{array}$ \\
\hline $\mathbf{2 0 1 6}$ & 436.28 & 114.87 & 321.41 \\
\hline $\mathbf{2 0 1 7}$ & 878.41 & 229.87 & 648.54 \\
\hline $\mathbf{2 0 1 8}$ & $1,326.46$ & 346.97 & 979.49 \\
\hline $\mathbf{2 0 1 9}$ & $1,780.49$ & 465.53 & $1,314.96$ \\
\hline $\mathbf{2 0 2 0}$ & $2,240.56$ & 585.55 & $1,655.01$ \\
\hline $\mathbf{2 0 2 1}$ & $2,687.98$ & 707.04 & $1,980.94$ \\
\hline $\mathbf{2 0 2 2}$ & $3,135.04$ & 830.00 & $2,305.04$ \\
\hline $\mathbf{2 0 2 3}$ & $3,581.68$ & 954.44 & $2,627.24$ \\
\hline $\mathbf{2 0 2 4}$ & $4,027.84$ & $1,080.36$ & $2,947.48$ \\
\hline $\mathbf{2 0 2 5}$ & $4,473.48$ & $1,207.78$ & $3,265.70$ \\
\hline
\end{tabular}

Source: Author's calculations.

Based on the information in Table 2.12, the best estimate for the present value of total cost of renewable electricity generation under a $25 \%$ RPS without TCs is $\$ 50.90$ billion. The cost decreases more than $\$ 12$ billion if the tax credit policies do not change until 2025. However, in reality, the future PTC policies for renewable electricity projects are uncertain. Taking the PTC for the wind power as an example, there is a boom-bust pattern for the development of wind power in the U.S. due to the "expiration and extension" cycle of the PTC (Wiser 2007; AWEA 2011). The short-term extension and the uncertainty of PTC may impede constant investments in wind power projects (Barradale 2010).

The PTC can reduce the utilities' financial burden to generate electricity from renewable energy sources when complying with a RPS, and promote the development of renewable energy projects in Michigan. Figure 4 exhibits the impacts of PTCs and ITCs 


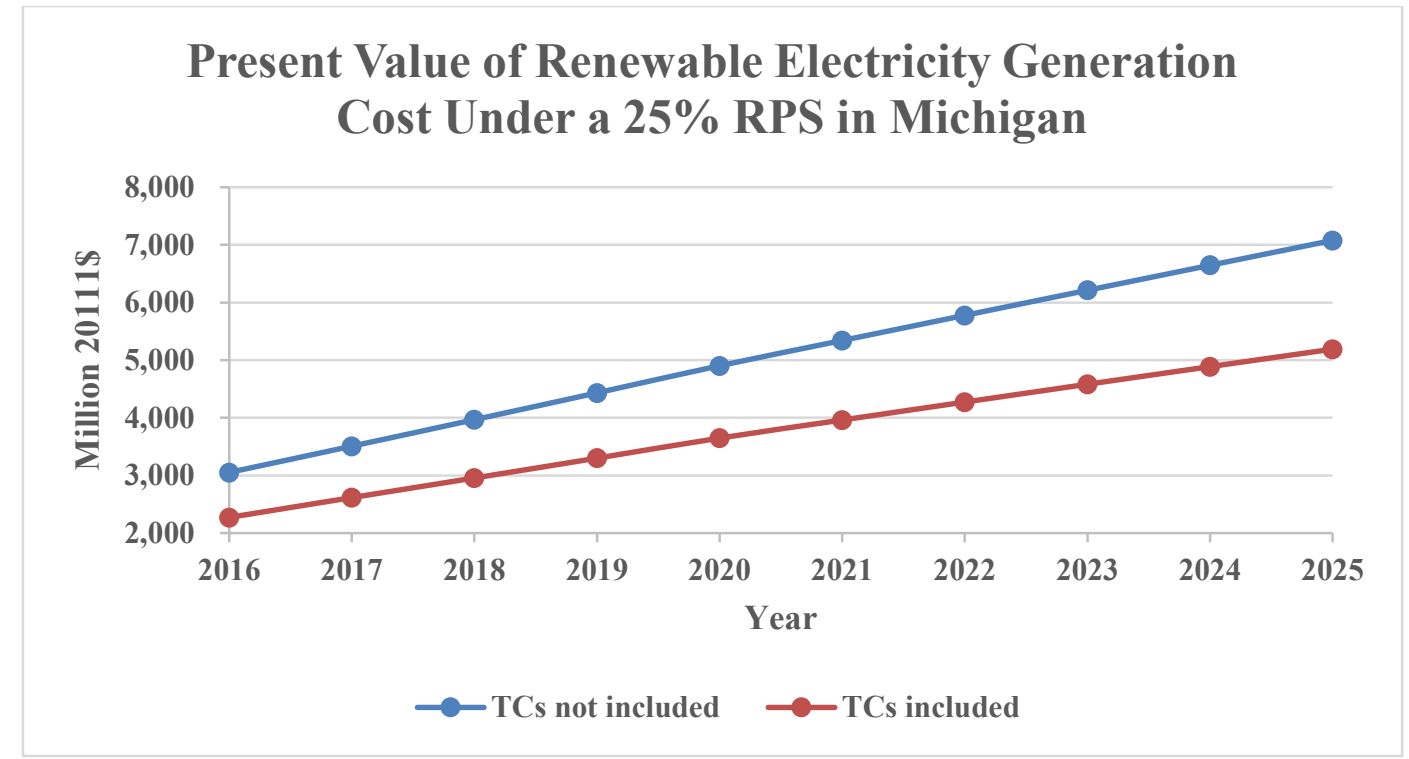

Figure 4: The Best Estimate for Present Value of the Cost of Renewable Electricity Generation With/Without TCs Under a 25\% RPS in Michigan

Source: Author's calculations.

on the generation cost of renewable electricity.

\subsection{Impacts on Ratepayer's Electricity Bills}

The previous analysis is based on the electricity producer's perspective. This section will turn to the electricity ratepayers in Michigan. The consumers are sensitive to increases in electricity rates. According to the failed Proposal 3, to protect electricity customers, the electricity rate could not be increased by more than $1 \%$ in any year for utilities to complete their obligations. This section will turn to the customers and discuss the impacts of $25 \%$ RPS on ratepayer's electricity bill. The annual increase in electricity rate equals the total cost of renewable electricity generation under a $25 \% \mathrm{RPS}$, which is presented in Table 2.12 and Table 2.16 , divided by the total electricity sales in a specific year, which is shown in Table 2.1. The utilities are mainly concerned with the total cost 
under a $25 \%$ RPS and are as focused on the marginal cost due to a $25 \%$ RPS when determining the electricity rate. Thus, the total cost of renewable electricity generation is used instead of the cost of additional required renewable electricity generation due to a $25 \%$ RPS. The results under with or without TCs scenarios are presented in Table 2.18, and lower and upper ranges are presented in the Appendix of the thesis.

With the expansion of renewable electric generating capacity, the increasing cost will inevitably result in increased electricity rates. Take the residential sector as an example: In Michigan, the average electricity price for the residential sector in March 2013 was 13.06 cents/kWh (in 2011\$) ${ }^{18}$. Using this figure to make an approximation, from the best estimate, it is possible that the increase in electricity rates in each year, which is influenced by the higher RPS, falls in a range from $21 \%$ to $48 \%$. The increase in electricity rate falls in a range from $18 \%$ to $40 \%$, and $25 \%$ to $56 \%$ in the estimated lower and upper scenarios. In the TCs included scenarios, the increase in electricity rate falls in a range from $13 \%$ to $28 \%, 16 \%$ to $34 \%$ and $20 \%$ to $43 \%$ in the lower, best estimate and upper scenarios. The increase is far more than the $1 \%$ cap set by the failed Proposal 3 in all estimates.

${ }^{18}$ See http://www.eia.gov/state/rankings/?sid=MI\#series/31. Retrieved on July 4, 2013. 


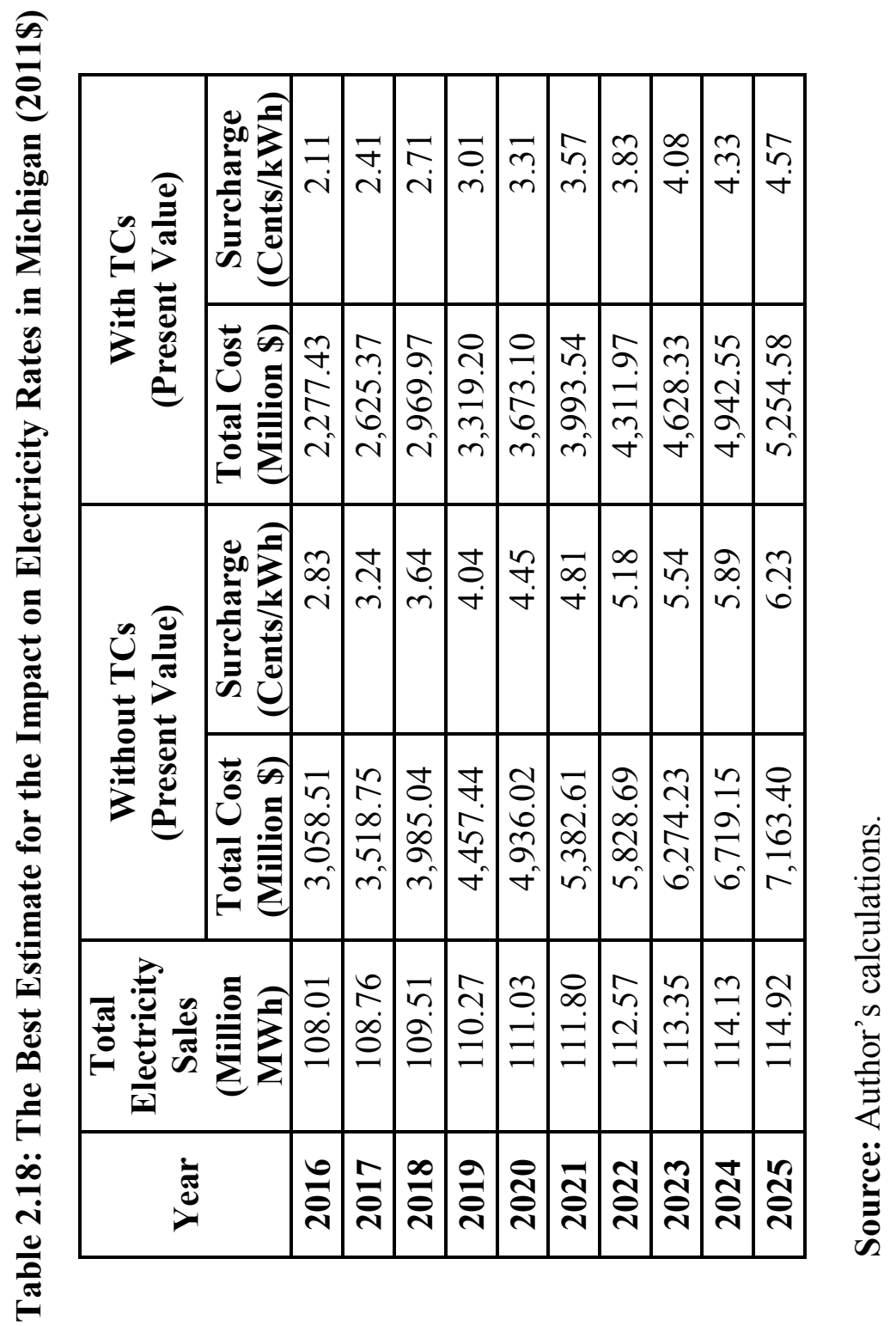




\section{Chapter 3: Benefits Analysis}

From the previous discussion, there will be a huge investment on expanding the current Michigan renewable electric power capacity for the State's utilities to fulfill a $25 \%$ RPS obligation by 2025 . Also, these costs will be transferred to the electricity customers, which will be reflected in increased electricity prices. The cost is huge: the present value of additional cost of renewable electricity generation cost is $\$ 7.87$ billion with tax credits scenario and $\$ 10.71$ billion without. Indisputably, however, generating electricity from renewable energy sources can significantly reduce pollutant emissions from traditional fossil fuels. Society can suffer less from pollutant emissions released from electricity production if more renewable energy resources, like wind power and solar energy, are adopted into the current electric power system. In this section, the benefits of a $25 \%$ RPS will be estimated. When conducting the benefits analysis, the scope of the study only focuses on Michigan, which means only the benefits of a $25 \%$ RPS for the residents in Michigan will be considered. The major benefits consists of three parts: 1) the avoided cost of generating electricity from fossil fuels; 2) human health and environmental benefits; and 3) other avoided externality costs. All of these benefits will be discussed subsequently in this section.

\subsection{The Avoided Electricity Generation Cost and the Net Generation Cost}

According to MPSC's 2011 Energy Overview, total coal use in Michigan was 37.4 million tons in 2009 and $94 \%$ of that was used to generate electricity. All the coal 
used for electric generation in Michigan is imported from other states. The production of natural gas in Michigan can only cover 18 percent of its demand, and the rest of the demand is met by imports (MPSC 2011). Therefore, to estimate the actual fossil fuel cost, the "revenue" from the avoided cost of generating electricity from coal and natural gas should be taken into consideration when calculating the benefits.

EIA's state electricity profiles ${ }^{19}$ show that coal and natural gas comprise most of the electricity generating sources in Michigan. For example, from 2006 to 2010, electricity generation from coal and natural gas accounts for nearly $70 \%$ of the total electricity generation annually. Nuclear power, hydropower and petroleum are the main sources for the rest of electricity production. Thus, it is reasonable to make the following assumption that the additional renewable electricity generation under a 25\% RPS only displaces the electricity generated from coal and natural gas. Recall from Table 1.1 that the hydropower energy potential in Michigan is small. The estimated capacity and generation potential are less than $1 \mathrm{GW}$ and $1 \mathrm{GWh}$. Moreover, the cost of an oil-power electricity plant is much higher and more people are concerned about the safety of the uses of nuclear energy. In the projection of substituted electricity generation from coal and natural gas, it is assumed that the substituted electricity generation for these two fossil fuels is based on their contributions to the total electricity sales in each year.

The annual electricity generation can be estimated by the following method. Based on the information from the 2013 AEO (EIA 2013), although coal continues to be the largest source for electricity production, the total market share of it is gradually

\footnotetext{
${ }^{19}$ More information can be found in Table 5. Electric Power Industry Generation by Primary Energy Source at http://www.eia.gov/electricity/state/michigan/. Retrieved on July 4, 2013.
} 
declining. Coal accounted for $42 \%$ of total U.S. electric generation in 2011 and is projected to account for $38 \%$ in 2025 . The proportion of total electricity generation from coal has a $0.67 \%$ compound annual decline rate. This figure can be applied to project its annual proportion of electricity generation from coal. Electricity generated from natural gas is projected to grow $1.6 \%$ from 2011 to 2040 annually. Its share of total electricity generation increases from $24 \%$ in 2011 to $27 \%$ in 2025 . The compound annual growth rate for its proportion of the total electricity generation is $0.79 \%$. From EIA's State Electricity Profile for Michigan $2010^{17}$, one can calculate that the electricity produced from coal accounts for about $72.2 \%$ of the total electricity generation in 2010 ; natural gas only produces about $1.3 \%$ of the total electricity in the same year. Although the electricity generation from natural gas in Michigan is far lower than the national level (24\%) in 2011 from the 2013 AEO's projection, a $0.79 \%$ annual compound growth rate is still adopted here to account for a growing role of natural gas in the future. Since only the 2010 data is available from EIA's states' electricity profiles, 2010 are adopted as the starting year for the approximation. By using the above increasing/decreasing rates of electric generation from coal and natural gas, Table 3.1 represents their annual proportion of total electricity production in Michigan from 2016 to 2025.

Recall that the additional required renewable electricity generation due to a $25 \%$ RPS in Table 2.8 reveals the difference between the renewable electricity generation under a $25 \%$ RPS and a $10 \%$ RES. If there were not a $25 \%$ RPS requirement, the calculated required total amount of the renewable electricity would be produced from coal and natural gas. By multiplying the electricity generation proportion in Table 3.1 by the additional required renewable electricity generation in Table 2.8 , the annual avoided 
Table 3.1: Annual Proportion of Electricity Generated from Coal and Natural Gas in Michigan

\begin{tabular}{|c|c|c|}
\hline Year & Coal & Natural Gas \\
\hline $\mathbf{2 0 1 6}$ & $69.35 \%$ & $1.36 \%$ \\
\hline $\mathbf{2 0 1 7}$ & $68.88 \%$ & $1.37 \%$ \\
\hline $\mathbf{2 0 1 8}$ & $68.42 \%$ & $1.38 \%$ \\
\hline $\mathbf{2 0 1 9}$ & $67.96 \%$ & $1.40 \%$ \\
\hline $\mathbf{2 0 2 0}$ & $67.51 \%$ & $1.41 \%$ \\
\hline $\mathbf{2 0 2 1}$ & $67.05 \%$ & $1.42 \%$ \\
\hline $\mathbf{2 0 2 2}$ & $66.60 \%$ & $1.43 \%$ \\
\hline $\mathbf{2 0 2 3}$ & $66.16 \%$ & $1.44 \%$ \\
\hline $\mathbf{2 0 2 4}$ & $65.71 \%$ & $1.45 \%$ \\
\hline $\mathbf{2 0 2 5}$ & $65.27 \%$ & $1.46 \%$ \\
\hline
\end{tabular}

Source: Author's calculations.

Table 3.2: Additional Avoided Electricity Generation from Coal and Natural Gas due to a 25\% PRS in Michigan (Thousand MWh)

\begin{tabular}{|c|c|c|c|}
\hline Year & $\begin{array}{c}\text { Total Avoided } \\
\text { Electricity Generation }\end{array}$ & Coal & $\begin{array}{c}\text { Natural } \\
\text { Gas }\end{array}$ \\
\hline $\mathbf{2 0 1 6}$ & $4,998.69$ & $4,902.34$ & 96.35 \\
\hline $\mathbf{2 0 1 7}$ & $10,062.10$ & $9,865.37$ & 196.73 \\
\hline $\mathbf{2 0 1 8}$ & $15,190.75$ & $14,889.46$ & 301.29 \\
\hline $\mathbf{2 0 1 9}$ & $20,385.14$ & $19,975.00$ & 410.13 \\
\hline $\mathbf{2 0 2 0}$ & $25,645.78$ & $25,122.37$ & 523.40 \\
\hline $\mathbf{2 0 2 1}$ & $30,973.18$ & $30,331.95$ & 641.23 \\
\hline $\mathbf{2 0 2 2}$ & $36,367.85$ & $35,604.10$ & 763.75 \\
\hline $\mathbf{2 0 2 3}$ & $41,830.31$ & $40,939.21$ & 891.10 \\
\hline $\mathbf{2 0 2 4}$ & $47,361.05$ & $46,337.62$ & $1,023.43$ \\
\hline $\mathbf{2 0 2 5}$ & $52,960.59$ & $51,799.71$ & $1,160.88$ \\
\hline Total & $\mathbf{2 8 5 , 7 7 5 . 4 4}$ & $\mathbf{2 7 9 , 7 6 7 . 1 4}$ & $\mathbf{6 , 0 0 8 . 3 0}$ \\
\hline
\end{tabular}

Source: Author's calculations. 
electricity generation from coal and natural gas are presented in Table 3.2.

When calculating the avoided electric generation cost, the electric generation technologies chosen for these two energy sources are still based on the "least-cost" criterion, which means that the utilities prefer to adopt the most inexpensive technology to expand or replace the current electric capacity. Table 3.3, which is based upon Table 2.7, represents the average estimate for the total system LECs for the selected power plants. The lower and upper ranges are shown in Appendix of this thesis.

Table 3.3: Average Total System LECs for Coal and Natural Gas Plants in the U.S. (2011 \$/MWh)

\begin{tabular}{|c|c|c|}
\hline Year & $\begin{array}{c}\text { Conventional } \\
\text { Coal }\end{array}$ & $\begin{array}{c}\text { Natural Gas-fired } \\
\text { (Advanced Combined Cycle) }\end{array}$ \\
\hline $\mathbf{2 0 1 6}$ & 100.1 & 65.6 \\
\hline $\mathbf{2 0 1 7}$ & 100.1 & 65.6 \\
\hline $\mathbf{2 0 1 8}$ & 100.1 & 65.6 \\
\hline $\mathbf{2 0 1 9}$ & 100.1 & 65.6 \\
\hline $\mathbf{2 0 2 0}$ & 100.1 & 65.6 \\
\hline $\mathbf{2 0 2 1}$ & 99.2 & 66.4 \\
\hline $\mathbf{2 0 2 2}$ & 98.3 & 67.2 \\
\hline $\mathbf{2 0 2 3}$ & 97.4 & 68 \\
\hline $\mathbf{2 0 2 4}$ & 96.5 & 68.8 \\
\hline $\mathbf{2 0 2 5}$ & 95.6 & 69.6 \\
\hline
\end{tabular}

Source: Author's calculations.

Based on the results from Table 3.2 and 3.3, one can compute the total avoided electric generation cost under a $25 \%$ RPS. The average cost is selected as the best estimate. The results are shown in Table 3.4 and the lower and upper ranges are presented 
Table 3.4: The Best Estimate for the Avoided Cost of Electricity Generation Under a 25\% RPS in Michigan (Million 2011\$)

\begin{tabular}{|c|c|c|c|}
\hline Year & Total & Conventional Coal & $\begin{array}{c}\text { Natural Gas-fired } \\
\text { (Advanced Combined Cycle) }\end{array}$ \\
\hline $\mathbf{2 0 1 6}$ & 497.05 & 490.73 & 6.32 \\
\hline $\mathbf{2 0 1 7}$ & $1,000.43$ & 987.52 & 12.91 \\
\hline $\mathbf{2 0 1 8}$ & $1,510.20$ & $1,490.44$ & 19.76 \\
\hline $\mathbf{2 0 1 9}$ & $2,026.40$ & $1,999.50$ & 26.90 \\
\hline $\mathbf{2 0 2 0}$ & $2,549.08$ & $2,514.75$ & 34.34 \\
\hline $\mathbf{2 0 2 1}$ & $3,051.51$ & $3,008.93$ & 42.58 \\
\hline $\mathbf{2 0 2 2}$ & $3,551.21$ & $3,499.88$ & 51.32 \\
\hline $\mathbf{2 0 2 3}$ & $4,048.07$ & $3,987.48$ & 60.59 \\
\hline $\mathbf{2 0 2 4}$ & $4,541.99$ & $4,471.58$ & 70.41 \\
\hline $\mathbf{2 0 2 5}$ & $5,032.85$ & $4,952.05$ & 80.80 \\
\hline
\end{tabular}

Source: Author's calculations.

in the Appendix of this thesis.

In the same manner as we calculated the present value of future cost, the benefits can be discounted by equation 4 :

$P V B=\sum_{t=0}^{t} B_{t}(1+r)^{-t}$

where: PVB $=$ Present Value of Total Benefits

$$
\begin{aligned}
& B_{t}=\text { Benefit in Year } \mathbf{t} \\
& \mathbf{r}=\text { Discount Rate }
\end{aligned}
$$

By using this formula, the present value of the total benefits from avoiding electricity generation from coal and natural gas is $\$ 27.56$ billion, with a range from $\$ 24.59$ billion to $\$ 32.67$ billion.

Solar and wind energies are intermittent energy sources. Different from dispatchable electricity generation technology, like coal or natural gas fired power plants, 
these non-dispatchable renewable electricity generation technologies are variable and less predictable. For example, the electricity generated from wind power is limited by the wind speed and solar electricity production can be influenced by sufficiency of the sunlight. The intermittency of renewable electric production is regarded as an externality. Some technical approaches can compensate for the shortcoming of intermittency, such as using dispatchable technologies as backup power to preserve the reliability of system; and preparing sufficient electricity storage capacity to fill the shortfall intermittency from wind or solar energy. According to Ford and Milborrow (2005), when taking account of the costs of variability, the additional costs of integrating wind were around $\$ 2.88 / \mathrm{MWh}$ and $\$ 4.32 / \mathrm{MWh}$ for $10 \%$ and $20 \%$ wind penetration worldwide. In this thesis, building up backup power from dispatchable technologies is taken as the only remedy for the intermittency of renewable electric generation among all the alternatives. Thus, the cost of building up backup capacity represents the cost of compensating for the intermittency of the dispatchable technologies.

There is no consistent conclusion about how much buildup capacity is needed to compensate for the intermittent energy. Some wind energy opponents argue that the wind plants need the same amount of backup electric power from fossil fuel plants, however, this statement is not true due to erroneous assumptions of how the electric system works ${ }^{20}$. Also, according to Utility Wind Interest Group (UWIG) (2003), the need for backup capacity compensated for intermittency of wind power is often closer to zero even at a moderate penetration of total electricity generation. After reviewing more than

${ }^{20}$ See http://www.awea.org/learnabout/publications/upload/Backup_Power.pdf. Retrieved on July 4, 2013. 
200 worldwide reports and studies, Gross (2006) concluded that the extra system balancing reserves due to short falls of generating electricity from wind power is about 5$10 \%$ of installed wind power capacity, if the penetration rate of intermittent renewables rises to $20 \%$ of total electricity supply. Thus, in the following calculations, it is assumed that the electricity generated from coal and natural gas, which equals $5 \%$ to $10 \%$ of electricity generation from solar and wind power, is needed as the backup reserves to compensate for the intermittency of renewable energy, and $7.5 \%$ is selected as the best estimate. Moreover, the proportion of electricity from coal and natural gas power plants as the backup generation is based on their projected contributions to the total electricity generation in Michigan, which is shown in Table 3.1. For example, in Table 3.1, the projected proportion of electricity generation from coal and natural gas fired plants are $69.35 \%$ and $1.36 \%$ in 2016 . Thus, the proportions of the compensating backup generation from coal and natural gas fired power plant are about $98.07 \%$ and $1.92 \%{ }^{21}$, respectively. Eventually, the annual required backup electricity generation can be calculated based on the information from Table 2.8 and Table 3.1. The results are shown in Table 3.5. The lower and upper ranges are shown in Appendix of this thesis.

Integrating the information in Table 3.3 and Table 3.5, the cost of backup electric capacity, which compensates for the intermittent renewable electricity generation technologies under a 25\% RPS in Michigan, is presented in Table 3.6. The lower and upper ranges are shown in the Appendix of this thesis. The cost of backup capacity will inevitably increase the electricity rates. After the calculation, the increase in electricity

21 The proportions are calculated as follows: $98.07 \%=\frac{69.35 \%}{69.35 \%+1.36 \%} ; 1.92 \%=\frac{1.36 \%}{69.35 \%+1.36 \%}$. 
Table 3.5: The Best Estimate for the Required Backup Electricity Generation in Michigan (MWh)

\begin{tabular}{|c|c|c|c|}
\hline Year & Total & Coal Power Plants & Natural Gas Power Plants \\
\hline $\mathbf{2 0 1 6}$ & $\mathbf{3 6 8 . 0 6}$ & 360.97 & 7.09 \\
\hline $\mathbf{2 0 1 7}$ & $\mathbf{7 4 0 . 6 3}$ & 726.15 & 14.48 \\
\hline $\mathbf{2 0 1 8}$ & $\mathbf{1 , 1 1 7 . 7 2}$ & $1,095.55$ & 22.17 \\
\hline $\mathbf{2 0 1 9}$ & $\mathbf{1 , 4 9 9 . 3 7}$ & $1,469.20$ & 30.17 \\
\hline $\mathbf{2 0 2 0}$ & $\mathbf{1 , 8 8 5 . 5 8}$ & $1,847.10$ & 38.48 \\
\hline $\mathbf{2 0 2 1}$ & $\mathbf{2 , 2 7 6 . 3 9}$ & $2,229.26$ & 47.13 \\
\hline $\mathbf{2 0 2 2}$ & $\mathbf{2 , 6 7 1 . 8 0}$ & $2,615.69$ & 56.11 \\
\hline $\mathbf{2 0 2 3}$ & $\mathbf{3 , 0 7 1 . 8 5}$ & $3,006.41$ & 65.44 \\
\hline $\mathbf{2 0 2 4}$ & $\mathbf{3 , 4 7 6 . 5 4}$ & $3,401.41$ & 75.12 \\
\hline $\mathbf{2 0 2 5}$ & $\mathbf{3 , 8 8 5 . 8 9}$ & $3,800.71$ & 85.18 \\
\hline
\end{tabular}

Source: Author's calculations.

Table 3.6: The Best Estimate for the Cost of Backup Capacity Compensating for Intermittent Renewable Electricity Generation Technologies Under a 25\% RPS in Michigan (Million 2011\$)

\begin{tabular}{|c|c|c|c|}
\hline Year & Total & Coal Power Plants & Natural Gas Power Plants \\
\hline $\mathbf{2 0 1 6}$ & $\mathbf{3 6 . 6 0}$ & 36.13 & 0.47 \\
\hline $\mathbf{2 0 1 7}$ & $\mathbf{7 3 . 6 4}$ & 72.69 & 0.95 \\
\hline $\mathbf{2 0 1 8}$ & $\mathbf{1 1 1 . 1 2}$ & 109.66 & 1.45 \\
\hline $\mathbf{2 0 1 9}$ & $\mathbf{1 4 9 . 0 5}$ & 147.07 & 1.98 \\
\hline $\mathbf{2 0 2 0}$ & $\mathbf{1 8 7 . 4 2}$ & 184.89 & 2.52 \\
\hline $\mathbf{2 0 2 1}$ & $\mathbf{2 2 4 . 2 7}$ & 221.14 & 3.13 \\
\hline $\mathbf{2 0 2 2}$ & $\mathbf{2 6 0 . 8 9}$ & 257.12 & 3.77 \\
\hline $\mathbf{2 0 2 3}$ & $\mathbf{2 9 7 . 2 7}$ & 292.82 & 4.45 \\
\hline $\mathbf{2 0 2 4}$ & $\mathbf{3 3 3 . 4 1}$ & 328.24 & 5.17 \\
\hline $\mathbf{2 0 2 5}$ & $\mathbf{3 6 9 . 2 8}$ & 363.35 & 5.93 \\
\hline
\end{tabular}

Source: Author's calculations. 
rates from building backup capacity is $0.03-0.32$ cents $/ \mathrm{kWh}, 0.02-0.19 \mathrm{cents} / \mathrm{kWh}$, and 0.05- 0.51 cents $/ \mathrm{kWh}$ in the lower, best estimate and upper scenarios.

The present value of the cost of compensating for the intermittency of the dispatchable technologies, namely, the cost of building backup generation is about $\$ 2.02$ billion, with a range from $\$ 1.20$ billion to $\$ 3.20$ billion. The net renewable electricity generation cost can be computed by using equation 5 :

NCREG = ACREG + CCIT - ACEG

where: NCREG $=$ Net Cost of Renewable Electricity Generation

\section{ACREG = Additional Cost of Renewable Electricity Generation CCIT $=$ Cost of Compensation for Intermittent Technologies ACEG = Avoided Cost of Electricity Generation from Fossil Fuels}

The best estimates for the annual net renewable electricity generation cost under a $25 \%$ RPS with TCs included or not included scenarios are shown in Table 3.7 and 3.8. The lower and upper ranges are shown in the Appendix of this thesis. The present value of the best estimate of net cost of renewable electricity generation is $-\$ 1.19$ billion, falling in a range from $-\$ 2.78$ billion to $-\$ 1.23$ billion. However, if TCs are included, the net cost is about $-\$ 7.65$ billion, with a range from $-\$ 9.23$ billion to $-\$ 7.71$ billion. All the net generation costs of renewable electricity in Table 3.7 and 3.8 are negative. That means if only considering the cost of additional cost of renewable electricity generation due to a $25 \%$ RPS and the avoided the electric production cost, even with the compensation cost for intermittency of renewable technologies taken into account, the net electricity generation cost is negative. Thus, the benefit from avoiding electricity generated from fossil fuels is larger than the sum of the cost of additional required renewable electricity 
Table 3.7: The Best Estimate for the Net Renewable Electricity Generation Cost Under a 25\% RPS in Michigan (Million 2011\$)

\begin{tabular}{|c|c|c|c|c|}
\hline Year & NREGC & ACREG & CCIT & ACEG \\
\hline 2016 & $(24.17)$ & 436.28 & 36.60 & 497.04 \\
\hline 2017 & $(48.38)$ & 878.41 & 73.64 & $1,000.43$ \\
\hline 2018 & $(72.62)$ & $1,326.46$ & 111.12 & $1,510.20$ \\
\hline 2019 & $(96.87)$ & $1,780.49$ & 149.05 & $2,026.40$ \\
\hline 2020 & $(121.11)$ & $2,240.56$ & 187.42 & $2,549.08$ \\
\hline 2021 & $(139.26)$ & $2,687.98$ & 224.27 & $3,051.51$ \\
\hline 2022 & $(155.28)$ & $3,135.04$ & 260.89 & $3,551.21$ \\
\hline 2023 & $(169.12)$ & $3,581.68$ & 297.27 & $4,048.07$ \\
\hline 2024 & $(180.75)$ & $4,027.84$ & 333.41 & $4,541.99$ \\
\hline 2025 & $(190.09)$ & $4,473.48$ & 369.28 & $5,032.85$ \\
\hline
\end{tabular}

Source: Author's calculations.

Table 3.8: The Best Estimate for the Net Renewable Electricity Generation Cost Under a 25\% RPS in Michigan (Tax Credits Included Scenario) (Million 2011\$)

\begin{tabular}{|c|c|c|c|c|}
\hline Year & NREGC & ACREG & CCIT & ACEG \\
\hline $\mathbf{2 0 1 6}$ & $(139.04)$ & 321.41 & 36.60 & 497.04 \\
\hline $\mathbf{2 0 1 7}$ & $(278.25)$ & 648.54 & 73.64 & $1,000.43$ \\
\hline $\mathbf{2 0 1 8}$ & $(419.59)$ & 979.49 & 111.12 & $1,510.20$ \\
\hline $\mathbf{2 0 1 9}$ & $(562.40)$ & $1,314.96$ & 149.05 & $2,026.40$ \\
\hline $\mathbf{2 0 2 0}$ & $(706.66)$ & $1,655.01$ & 187.42 & $2,549.08$ \\
\hline $\mathbf{2 0 2 1}$ & $(846.29)$ & $1,980.94$ & 224.27 & $3,051.51$ \\
\hline $\mathbf{2 0 2 2}$ & $(985.27)$ & $2,305.04$ & 260.89 & $3,551.21$ \\
\hline $\mathbf{2 0 2 3}$ & $(1,123.56)$ & $2,627.24$ & 297.27 & $4,048.07$ \\
\hline $\mathbf{2 0 2 4}$ & $(1,261.11)$ & $2,947.48$ & 333.41 & $4,541.99$ \\
\hline $\mathbf{2 0 2 5}$ & $(1,397.87)$ & $3,265.70$ & 369.28 & $5,032.85$ \\
\hline
\end{tabular}

Source: Author's calculations.

*Note: NCREG $=$ Net Cost of Renewable Electricity Generation ACREG $=$ Additional Cost of Renewable Electricity Generation CCIT $=$ Cost of Compensation for Intermittent Technologies $\mathrm{ACEG}=$ Avoided Cost of Electricity Generation from Fossil Fuels 
generation and the expenditure on backup electricity generation.

\subsection{Environmental and Human Health Benefits of a 25\% RPS}

Large amounts of pollutants are emitted when electricity is generated in a traditional fossil fuel power plant. Taking coal as an example, although the annual U.S. share of electricity generation from coal decreased from $49.6 \%$ in 2007 to $37.4 \%$ in $2012^{22}$, it has been the largest source of electricity generation for over 60 years ${ }^{23}$ and still generates the most electricity among all the available energy sources. According to Sueyoshi et al. (2010), coal-fired power plants release about $59 \%$ of total $\mathrm{SO}_{2}$ emissions, $18 \%$ of total $\mathrm{NO}_{\mathrm{x}}$ emissions, and $50 \%$ of particulate pollution every year in the U.S. Power plants also emit large quantities of mercury and other hazardous air toxics, and over $40 \%$ of total carbon dioxide $\left(\mathrm{CO}_{2}\right)$ in the U.S. When generating an equal amount of energy, burning coal can generate 1.5 and 2 times the $\mathrm{CO}_{2}$ emissions from burning oil and natural gas separately (Epstein et al. 2011). Taking the electric power sector as a whole, it accounts for the largest emission source (about 33\%) of the total greenhouse gas emissions $^{24}$.

Nearly all pollutants have negative impacts on the environment and human health. According to the U.S. Environmental Protection Agency (EPA), $\mathrm{SO}_{2}$ and $\mathrm{NO}_{\mathrm{x}}$ and their particulate matter derivatives, sulfates and nitrates, can degrade visibility and threaten

\footnotetext{
${ }^{22}$ See http://www.eia.gov/electricity/. Retrieved on May 7, 2013.

${ }^{23} \mathrm{See}$ http://www.eia.gov/energy_in_brief/article/role_coal_us.cfm. Retrieved on May 7, 2013.

${ }^{24} \mathrm{See}$ http://www.epa.gov/climatechange/ghgemissions/sources/electricity.html\#ref1. Retrieved on May 7 , 2013.
} 
human health (such as though respiratory disease). Acid rain, which is formed by $\mathrm{SO}_{2}$ and $\mathrm{NO}_{\mathrm{X}}$, can accelerate the decay of buildings and deterioration of ecosystems ${ }^{25}$. These pollutants are negative externalities. An externality exists when the action of one economic agent affects the utility of another agent and is unaccounted for. Since there are no market values for the involved variables, such actions are not controlled (Kammen and Pacca 2004). Normally, an externality is unpriced, unintentional and uncompensated (Baumol and Oates 1988). One way to eliminate the externality is to internalize it. Incorporating the human health and environmental costs into setting the electricity price is an effective way to eliminate the negative externality from electric generation. Sovacool (2008) estimated the real cost of electricity generation, including external cost, from various energy sources. In the study, if the externality were taken into account when calculating the cost of power generators, the true cost of per unit electricity generated from scrubbed coal will be about four times as large as the cost without including the externality. Current electricity customers are charged based only on providers' private cost, which consists of the cost of the fuel, expenses for operation and maintenance, investment on transmission for electricity providers, and other regulatory costs. However, the full social cost is generally excluded from consideration in the electricity pricing system. Ultimately, the losses to society as a whole from pollutant emissions are not compensated for at all.

Compared with conventional approaches, generating electricity from renewable

${ }^{25}$ See EPA's Acid Rain Program website: http://www.epa.gov/airmarkets/progsregs/arp/basic.html. Retrieved on May 7, 2013. 
sources is clean and reduces the externalities from pollutant emissions (Borenstein 2011). Wind and solar energy produce zero air emissions during electricity generation. Also, according to Heller et al. (2004), at a 10\% willow biomass cofiring rate, the plant can reduce net $\mathrm{SO}_{2}$ emissions by $9.5 \%$ and provide a significant $\mathrm{NO}_{\mathrm{x}}$ emission reduction. Moreover, according to Burtraw et al. (1998), huge benefits can be gained by pollutant emission reductions. They evaluated the benefits and costs of Title IV of the 1990 Clean Air Act Amendments (the US Acid Rain Program), which requires electric power plants to reduce their $\mathrm{SO}_{2}$ and $\mathrm{NO}_{\mathrm{x}}$ emissions. The findings indicated that in the default scenario, the program could create $\$ 5$ billion, $\$ 20$ billion, and $\$ 15.5$ billion benefits in 1995, 2020 and 2030 respectively. The total annual quantified benefits of Title IV were $\$ 122,000$ million in 2010 (Chestnut et al. 2005). According to Fann et al. (2009), the benefit of reducing pollutant emissions per ton varies by geographic location and PM2.5

precursor. For example, in their study, the value per ton based on $\mathrm{SO}_{\mathrm{x}}$ in urban areas of New York/Philadelphia is $\$ 14,000$, however, the benefit increases 10 times $(\$ 140,000)$ in the Dallas urban area.

Therefore, a RPS can be a powerful instrument to reduce the pollutant emissions from electricity generation. In the following section, the emission reductions for major air pollutants will be estimated. Finally, these results will be applied to estimate the human health and environmental benefits of a $25 \%$ RPS.

\subsubsection{Air Pollutant Emission Reductions}

An emission factor represents the pollutant emission for one specific pollutant per 
unit of electricity generation. It can be used to estimate pollutant emissions by multiplying the emission factors by the total amount of electricity generated from one specific energy resource. The air emissions of electricity generation from renewable energy sources are much smaller than the ones from fossil fuels. However, processing the materials for renewable electricity generation technologies, especially for solar cells, can be very energy intensive. For example, $2400-7600 \mathrm{MJ} / \mathrm{m}^{2}$ of primary energy is consumed for $\mathrm{mc}-\mathrm{Si}$, and $5300-16,500 \mathrm{MJ} / \mathrm{m}^{2}$ for mono-Si modules (Alsema 2000). Therefore, a large quantity of air pollutants can be emitted from the energy input for processing the solar cell. To indicate the net pollutant emissions from electricity production from different energy sources, especially incorporating the pollutant emissions from renewable electricity production, this thesis applies emission factors for different technology-based electricity power plants from Life-Cycle Assessment (LCA) studies. In the power sector, an LCA assesses all the steps that are involved in generating electricity, which should include extracting, processing and transporting the fuels, building power plants, generating electricity and disposing of waste (Gagnon et al. 2002).

Criteria air pollutants $\mathrm{CO}, \mathrm{SO}_{2}, \mathrm{NO}_{\mathrm{x}}$ and $\mathrm{PM}$, and major climate change contributor $\mathrm{CO}_{2}$ are selected as the targeted pollutants. The findings from Spath et al. (1999), Spath and Mann (2000), and Pehnt (2006) are applied in this thesis for different technology-based power plants. To utilize uniform units, it is necessary to do some adjustments, and the emission factors for different kinds of electricity generation technologies are presented in Table 3.9.

One can compute pollutant emissions under a $25 \%$ RPS via multiplying the figures in Table 3.9 by the ones in Table 2.8, which shows the additional total renewable 
Table 3.9: Emission Factors for Different Power Plants (Kg/ MWh)

\begin{tabular}{|c|c|c|c|c|c|}
\hline Power Plant Type & $\mathbf{C O}_{2}$ & $\mathbf{C O}$ & $\mathbf{S O}_{2}$ & $\mathbf{N O}_{\mathbf{x}}$ & $\mathbf{P M}$ \\
\hline Coal-fired Plants $^{\mathrm{a}}$ & $1,020.00$ & 0.27 & $6.70^{\mathrm{c}}$ & $3.35^{\mathrm{d}}$ & 9.21 \\
\hline Natural Gas Combined Cycle $^{\mathrm{b}}$ & 440.00 & 0.29 & $0.32^{\mathrm{c}}$ & $0.57^{\mathrm{d}}$ & 0.13 \\
\hline Solar PV $_{\text {Biomass }^{\mathrm{e}}}$ & 99.00 & 0.14 & 0.29 & 0.34 & 0.12 \\
\hline Landfill Gas $^{\mathrm{f}}$ & 31.00 & 0.41 & 0.32 & 1.32 & 0.11 \\
\hline Wind (Onshore) $^{2}$ & 11.00 & 0.72 & 0.37 & 0.58 & 0.04 \\
\hline & 10.20 & 0.10 & 0.04 & 0.03 & 0.04 \\
\hline
\end{tabular}

Note:

${ }^{a}$ The figures represent for the average coal-fired power plant in the U.S.

${ }^{\mathrm{b}}$ The figures represent for the average air emissions in the U.S.

c $\mathrm{SOx}$ as $\mathrm{SO}_{2}$.

${ }^{\mathrm{d}} \mathrm{NO}_{\mathrm{x}}$ as $\mathrm{NO}_{2}$.

e Using the figures for "Waste wood steam turbine" for approximation from Pehnt (2006).

${ }^{\mathrm{f}}$ Using the figures for "Biogas" for approximation from Pehnt (2006).

Sources: Pehnt (2006); Spath et al. (1999); Spath and Mann (2000).

electricity generation due to a $25 \%$ RPS. Similarly, the avoided pollutant emissions can be computed through multiplying the figures in Table 3.8 and the ones in Table 3.2, which presents the additional avoided electricity generation from coal and natural gas. The net avoided pollutant emissions under a 25\% RPS equal the difference between the pollutant emissions from renewable electricity generation and the avoided emissions from coal and natural gas, as shown in equation 6 :

$\mathbf{E}^{*}=\mathbf{E}-\mathbf{E}^{\prime}$

where: $\mathbf{E}^{*}=$ Net Air Pollutant Emission Reductions

E $=$ Avoided Air Pollutant Emissions of Generating Electricity from Coal and Natural Gas 


\section{E' =Air Pollutant Emissions of Generating Electricity from Renewable Energy}

The annual avoided pollutant emissions under a 25\% RPS from 2016 to 2025 are shown in Table 3.10.

Table 3.10: Annual Avoided Pollutant Emissions Under a 25\% RPS from 2016 to 2025 in Michigan (Thousand Tons)

\begin{tabular}{|c|c|c|c|c|c|}
\hline Year & $\mathbf{C O}_{\mathbf{2}}$ & $\mathbf{C O}$ & $\mathbf{S O}_{\mathbf{2}}$ & $\mathbf{N O}_{\mathbf{x}}$ & $\mathbf{P M}$ \\
\hline $\mathbf{2 0 1 6}$ & $4,987.93$ & 0.82 & 32.65 & 16.20 & 44.94 \\
\hline $\mathbf{2 0 1 7}$ & $10,038.57$ & 1.66 & 65.70 & 32.60 & 90.45 \\
\hline $\mathbf{2 0 1 8}$ & $15,152.33$ & 2.50 & 99.16 & 49.19 & 136.51 \\
\hline $\mathbf{2 0 1 9}$ & $20,329.63$ & 3.35 & 133.02 & 65.98 & 183.13 \\
\hline $\mathbf{2 0 2 0}$ & $25,570.87$ & 4.21 & 167.30 & 82.98 & 230.32 \\
\hline $\mathbf{2 0 2 1}$ & $30,876.46$ & 5.08 & 201.99 & 100.17 & 278.08 \\
\hline $\mathbf{2 0 2 2}$ & $36,246.81$ & 5.96 & 237.10 & 117.57 & 326.42 \\
\hline $\mathbf{2 0 2 3}$ & $41,682.30$ & 6.85 & 272.62 & 135.16 & 375.33 \\
\hline $\mathbf{2 0 2 4}$ & $47,183.32$ & 7.75 & 308.57 & 152.96 & 424.82 \\
\hline $\mathbf{2 0 2 5}$ & $52,750.26$ & 8.66 & 344.93 & 170.97 & 474.89 \\
\hline Total & $284,818.47$ & 46.83 & $1,863.05$ & 923.78 & $2,564.88$ \\
\hline
\end{tabular}

Source: Author's calculations.

Recall that some measures should be taken to compensate for the intermittency of renewable electricity generation technologies. In Section 3.1, constructing backup electric generation capacity is selected as way to do it. Definitely, the backup electricity generated from coal and natural gas will contribute to more pollutant emissions.

However, the pollutant emissions from backup electricity production are excluded from the calculation for the total avoided pollutant emissions because expanding electricity generation capacity is one of the available solutions for compensating for the weakness of 
intermittent renewable energies. Thus, because of the uncertainty of which technology will be applied, the cost of building backup electricity generation represents the cost compensated for the intermittency of renewable electricity generation technologies when calculating the cost of net renewable electricity generation cost.

From 2016 to 2025, a 25\% RPS can reduce $\mathrm{CO}_{2}, \mathrm{SO}_{2}$, and PM emissions by about 284.82, 1.86 and 2.56 million tons, respectively. Additionally, nearly 46.83 and 923.78 thousand tons of $\mathrm{CO}$ and $\mathrm{NO}_{\mathrm{x}}$ can be avoided. It is obvious that the RPS not only contributes to a diversified and sustainable energy system, but it can also generate environmental benefits. Additionally, huge amounts of pollutant emissions result in human health problems. The next section will estimate the total human health and environmental benefits from the emission reductions if a new RPS is implemented.

\subsubsection{Human Health and Environmental Benefits from Air Pollutant Emission Reductions}

When estimating the benefits from pollutant emission reductions, the damage cost of pollutant emission or the benefit of avoiding pollutant emissions from the electricity generation varies between studies. By reviewing the previous electricity externality cost studies, Sundqvist (2004) concluded that discrepancies among studies can be based on methodological reasons and problems when methods are applied. Although Sundqvist concluded that the disparity of results due to site specificity were not shown, from Banzhaf et al. (1996), the benefits of pollutant emission reductions vary based on location of the power plants. For example, the potential damage cost range per ton $\mathrm{SO}_{2}$ emission for a power plant in a rural scenario is from $\$ 9$ to $\$ 24(1993 \$)$. However, the cost range 
for the one in an urban scenario is from $\$ 106$ to $\$ 178$. The study only focuses on the benefits within Wisconsin and Minnesota, but long-range transport benefits are not included. It is assumed that the findings from the study of the neighbor states are applicable to estimate the benefits of avoiding pollutant emissions of a $25 \%$ RPS in Michigan. Therefore, the human health cost, agriculture cost, and visibility cost at the state level in their study are applied here to calculate the human health and environmental benefits. In the original study, the damage cost is categorized by the plant's location. After integrating all the types of locations of the power plants - rural, metropolitan, and urban - the estimated ranges of damage costs for different kinds of pollutants emitted from electricity generation are listed in Table 3.11. According to Pachauri and Reisinger (2007), the range of social costs for emitting one ton of $\mathrm{CO}_{2}$ across the globe is from $-\$ 3$ to $\$ 95$ with an average of $\$ 12(2007 \$)$. Since the damage cost per ton of $\mathrm{CO}_{2}$ in Michigan or the states close to Michigan is unavailable, the social cost of $\mathrm{CO}_{2}$ in Pachauri and Reisinger's study are adopted as the damage cost of $\mathrm{CO}_{2}$ in the following calculation. After the conversion, the range of damage cost of per ton of pollutant emission is presented in Table 3.11 .

Table 3.11: The Range of Potential Damage Cost for Different Pollutant Emissions (2011\$/Ton)

\begin{tabular}{|c|c|c|c|}
\hline Pollutant & Lower Range & Average & Upper range \\
\hline $\mathbf{C O}_{2}$ & $(3.42)$ & 12.97 & 102.68 \\
\hline $\mathbf{C O}$ & 0.31 & 1.795 & 3.28 \\
\hline $\mathbf{S O}_{2}$ & 13.8 & 143.32 & 272.84 \\
\hline $\mathbf{N O}_{\mathbf{x}}$ & 10.73 & 141.02 & 271.31 \\
\hline $\mathbf{P M}$ & 812.38 & 5045.975 & 9279.57 \\
\hline
\end{tabular}

Sources: Pachauri and Reisinger (2007); Banzhaf et al. (1996). 
Here are some explanations about the estimates in Table 3.11. First, the average costs for different pollutant emissions reflect the average cost of the lower and upper cost ranges, which will be selected as the best estimate in the following calculations. Second, the benefits from avoided damage costs can be calculated by multiplying the avoided pollutant emissions by the damage cost per unit of emission. Using the figures in Table 3.10 and Table 3.11, the results are provided in Table 3.12. The lower and upper ranges are shown in the Appendix of the thesis. Taking the average figures as the best estimate, the total avoided damage cost from air pollutant emissions reduction is about $\$ 17.03$ billion, in a range from $\$ 1.15$ billion to $\$ 53.81$ billion.

Based on the results in Table 3.12, the net present value of the best estimate for the total avoided damage cost from air pollutant emission is $\$ 16.88$ billion, falling in the range from $\$ 1.13$ billion to $\$ 53.32$ billion. Also from the Banzhaf et al. (1996) study, the cost of potential health damage, which falls in a range from $56 \%$ to $80 \%$ of total damage, accounts for the largest amount of damages. The agricultural damages are the second largest damage category, which accounts for $15 \%$ to $25 \%$ of total damages. Materials and visibility damages make up a smaller percentage of the total damage, which never exceed $11 \%$ of the total amount. Taking the average figures as the best estimates, the ranges for the present value of different kinds of benefits under the best estimate scenario are shown in Table 3.13.

$\mathrm{CO}_{2}$ does not have direct impacts on the above three categories. Thus, when computing the ranges for different benefit categories, the impacts from $\mathrm{CO}_{2}$ are excluded. In the best estimate scenario, the present value of human health benefits fall in a range 


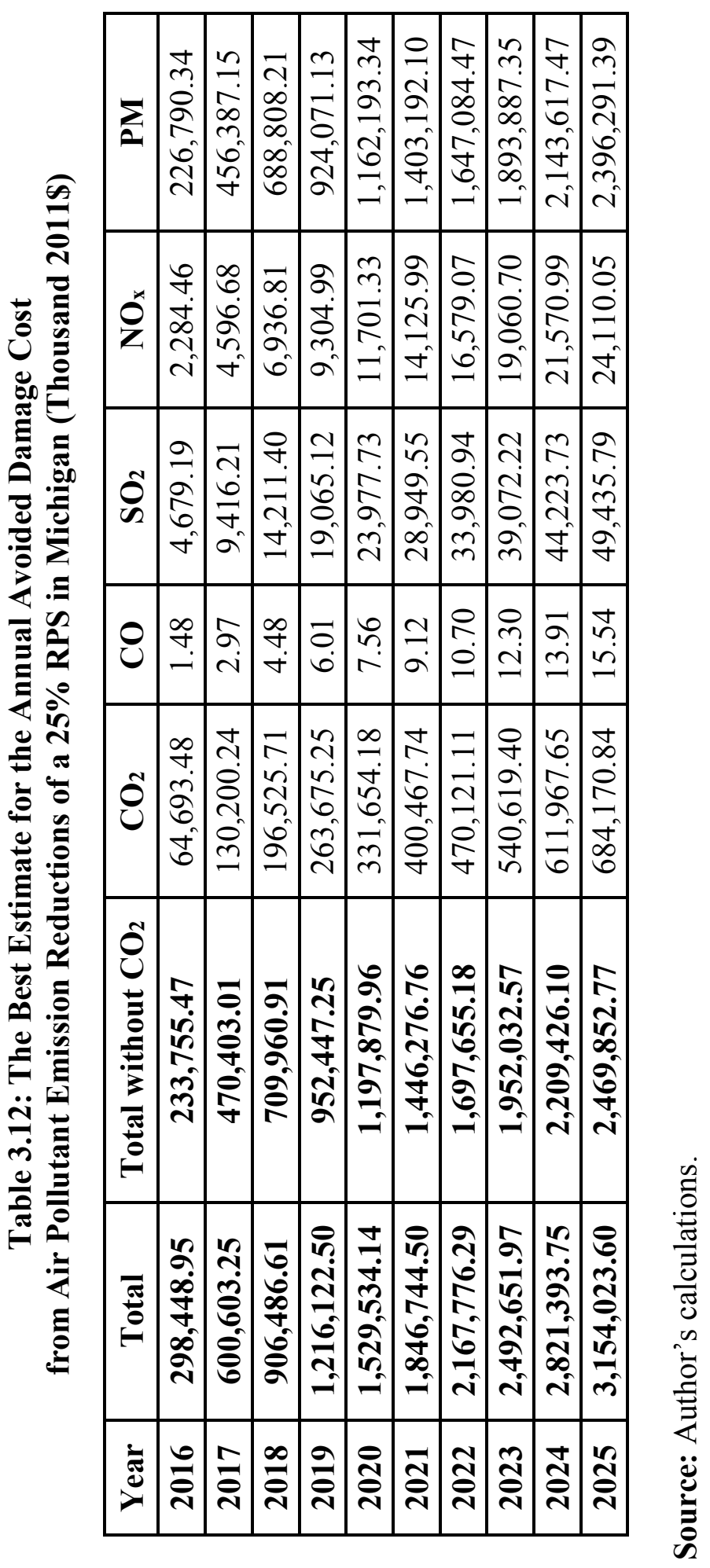


Table 3.13: The Present Value Ranges for Different Types of Benefits of a 25\% RPS in Michigan Under the Best Estimate Scenario (Million 2011\$)

\begin{tabular}{|c|c|c|}
\hline Benefit Type & Low & High \\
\hline Human Health & $7,403.08$ & $10,575.83$ \\
\hline Agriculture & $1,982.97$ & $3,304.95$ \\
\hline Material and Visibility & \multicolumn{2}{|c|}{ Not exceeding $1,454.18$} \\
\hline
\end{tabular}

Source: Author's calculations.

from $\$ 7.40$ billion to $\$ 10.58$ billion under a $25 \%$ RPS. Agriculture gains the benefits from $\$ 1.98$ billion to $\$ 3.30$ billion dollars. Additionally, the material and visibility benefits do not exceed $\$ 1.45$ billion.

\subsection{Benefits from Avoiding Other Externalities}

To estimate the real cost per unit of electricity generation, there are other externalities besides air pollutant emissions that should be taken into account. Roth and Ambs (2004) discussed externalities from different power plants in their study. For example, the land externalities from occupying land for power plant and storing fuel, condenser water from power plants, negatively affects aquatic life. Also, solid waste and toxic emissions from power plants can create negative externalities. Although renewable energy technologies produce few or no pollutants during electricity generation, they still have some adverse externalities. Taking wind power as an example, noise, visual disamenities, emission related to wind turbine production, related accidents, impacts on birds are the externalities that should be taken into LEC of wind turbines (Schleisner 2000). One of the greatest concerns is bird deaths from wind farms. According to 
Manville and Albert (2005), 40,000 birds are killed by wind turbines in the U.S. annually. To have a full view of electricity generation, these externalities should not be ignored. Table 3.14 is reproduced from Roth and Ambs (2004), which shows the best estimate external cost of electricity generation from different technologies. The lower and upper range can be found in the Appendix of this thesis.

Here are some assumptions for the figures in Table 3.14. Roth and Ambs (2004) assume that the cost of land use externality for biomass power plants can be neglected because the wood residue is acquired from the land used for other purposes. The reason why zero land use external cost is assigned to landfill gas recovery power plants is because they are assumed to occupy land used to store waste. The water related externalities stem from the negative effects of the solid wastes from power plants. This kind of external cost from biomass and landfill gas power plants is excluded from estimation. Aquatic life can be affected adversely when the power plants extract and return condensed water from nearby water resources. This negative effect represents the wildlife related externalities. The external cost is estimated based on the installation of a closed loop cooling system, which can eliminate impacts on aquatic life.

Roth and Ambs (2004) also studied non-environmental external costs from energy security, based on a literature review. This kind of externality originates from ensuring the fossil fuel supply and its risks of disruption from foreign markets, and the depletion of nonrenewable energy and its limitation of the option of energy supply in the future. However, generating electricity from coal or natural gas can enhance energy security as much as can renewable energy sources. Also, generating electricity from coal and natural gas is cheaper. That makes electric transportation more affordable and enhances energy 


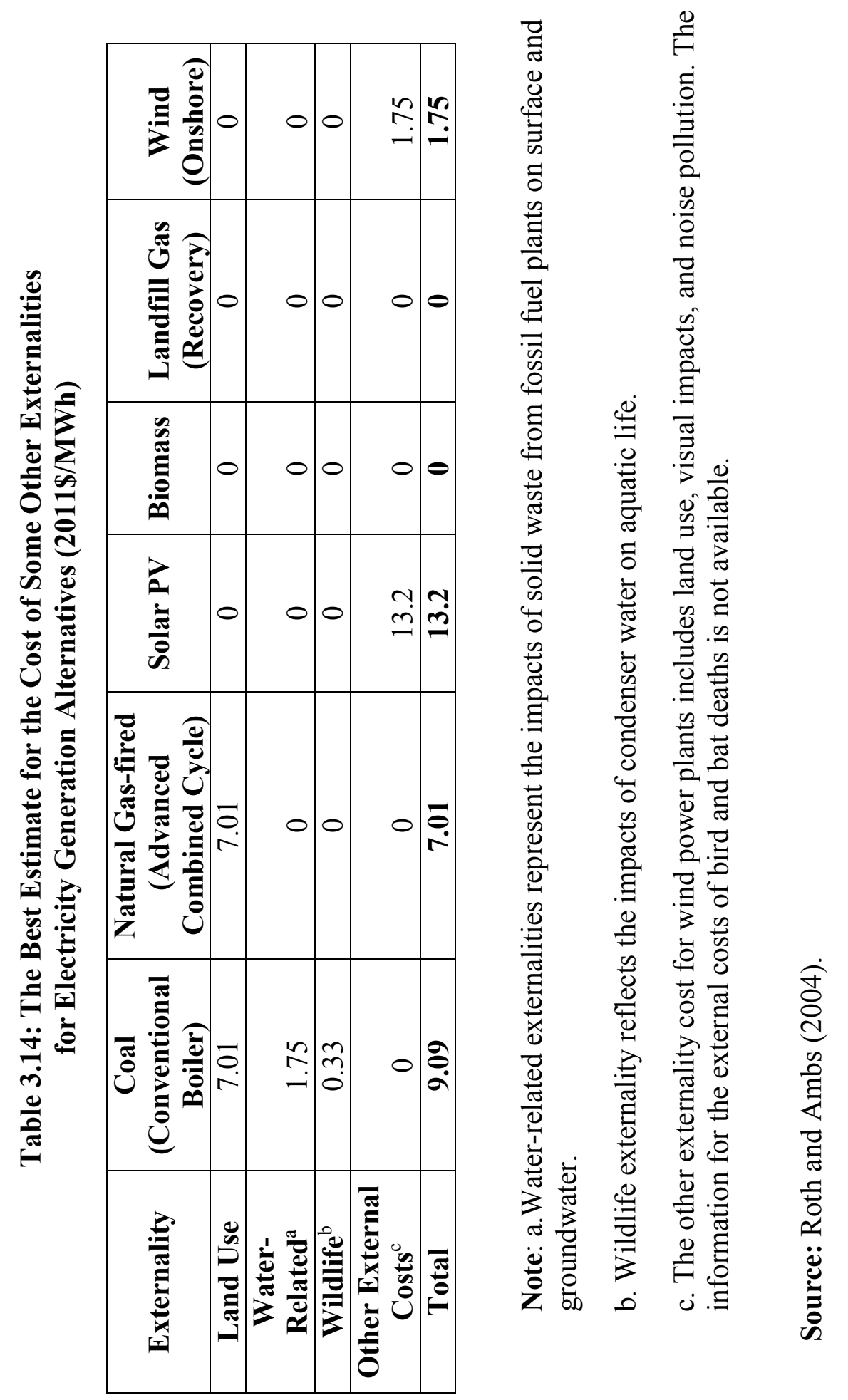


security. Moreover, compared with the world oil market, the quantity of oil uses for electricity generation in the U.S. is very small (Borenstein 2011) and negligible in Michigan (See Chapter1). Therefore, the external cost of energy security is excluded from the calculation of external cost in this thesis.

By multiplying the total avoided electricity generation from the selected types of coal and natural gas power plants in Table 3.2, and the total renewable electricity generation under a 25\% RPS in Table 2.8 by the total costs of other externalities per unit electricity generation in Table 3.12 individually, one can compute the external cost savings from avoiding electricity generation from coal and natural gas, and the external costs from renewable electricity generation. The net avoided cost of other externalities can be calculated by equation 7:

$\mathbf{C}^{*}=\mathbf{C}-\mathbf{C}^{\prime}$

where: $C^{*}=$ Net Avoided Cost of Other Externalities C = Avoided External Cost of Electricity Generation from Coal and Natural Gas

$C^{\prime}=$ External Costs of Renewable Electricity Generation

The best estimates for the benefits of avoiding the externalities besides the ones from air pollution under a 25\% RPS are presented in Table 3.15. The present value of avoiding the externalities other than air pollutant emissions under a 25\% RPS is about $\$ 2.06$ billion, with a range from $\$ 1.30$ billion to $\$ 6.97$ billion. More information about the lower and upper ranges for avoided externality cost can be found in the Appendix of this thesis. 
Integrating all the information in the previous sections, the present value of net benefits of a $25 \%$ RPS can be calculated. Table 3.16 shows the results. The best estimate for the present value of total benefits from implementing a $25 \%$ RPS is $\$ 46.50$ billion, with a range from $\$ 27.03$ billion to $\$ 92.96$ billion. 


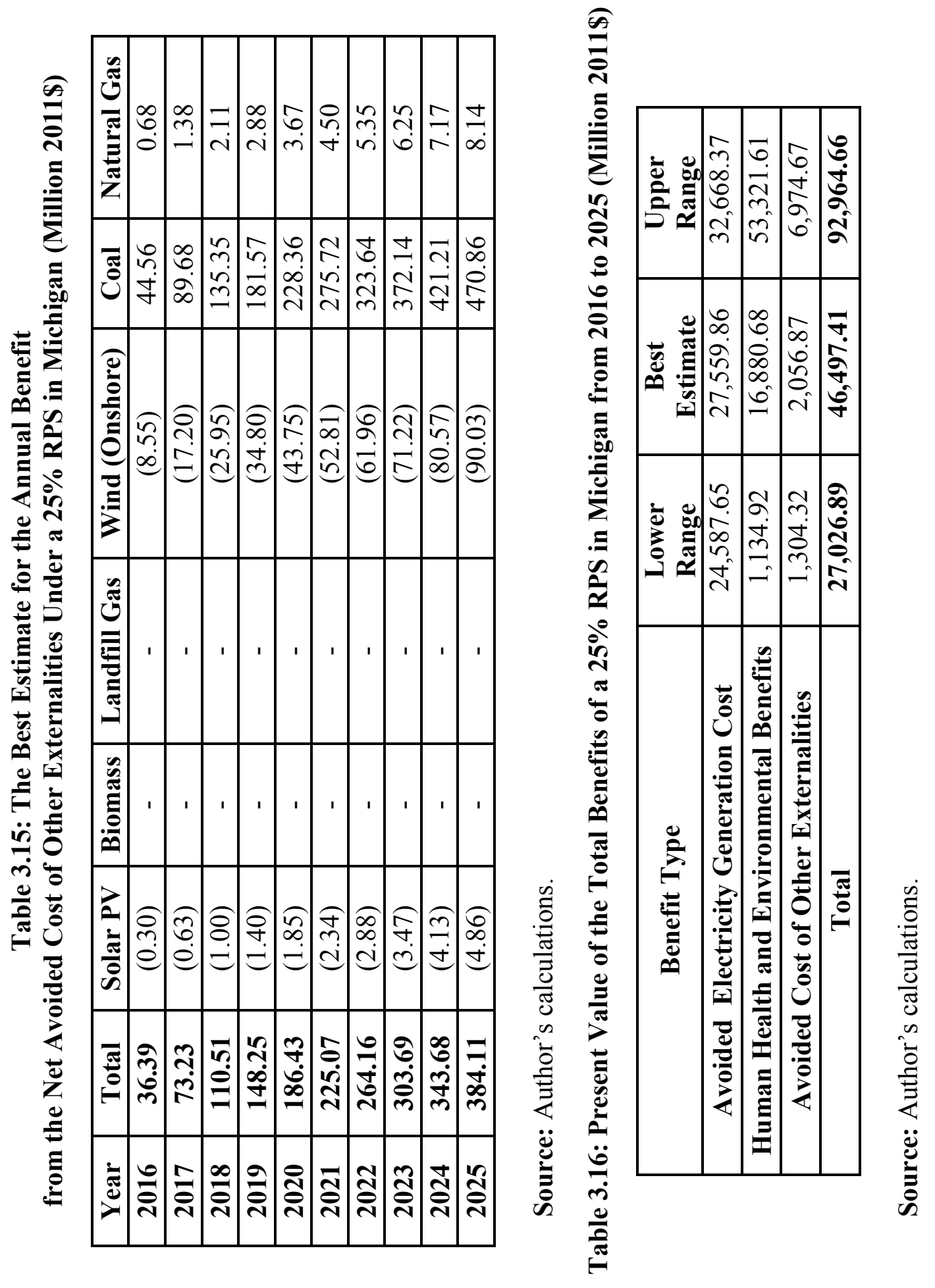




\section{Chapter 4: Conclusion and Discussion}

\subsection{Conclusion}

From the results of cost-benefit analysis in the previous sections, it is easy to calculate the discounted net present value of implementing a 25\% RPS in Michigan from 2016 to 2025 . The net present value can be calculated by equation 8 :

$\mathbf{N P V}=\mathbf{N P B}-\mathbf{N P C}$

where: NPV $=$ Discounted Net Present Value

\section{NPB = Discounted Present Value of Total Benefits}

\section{NPC $=$ Discounted Present Value of Total Costs}

Based on the cost-benefit analysis criteria, if the discounted net present value is positive, the project or the proposal should be approved; otherwise, if the discounted net present value does not exceed zero, it should not go ahead. The results of the discounted net present value analysis of a 25\% RPS are shown in Table 4.1 .

It is obvious from Table 4.1 that the results pass the cost-benefit analysis criteria. The best estimate indicates that a 25\% RPS will generate about $\$ 20.12$ billion net benefits from 2016 to 2025 in Michigan. Also, the lower and upper ranges strongly suggest that the residents in Michigan can benefit from a higher RPS. Thus, a 25\% RPS should be approved. Table 4.2 shows the net present value in the TCs included scenario. If all the TC policies do not change until 2025, the net present values in all the estimated ranges pass the cost-benefit analysis test: a 25\% RPS will create about $\$ 26.59$ billion, falling in a range from $\$ 11.67$ billion to $\$ 68.00$ billion, to the residents in Michigan from 
Table 4.1: Net Present Value of a 25\% RPS in Michigan from 2016 to 2025 (Million 2011\$)

\begin{tabular}{|c|c|c|c|c|}
\hline & $\begin{array}{c}\text { Lower } \\
\text { Range }\end{array}$ & $\begin{array}{c}\text { Best } \\
\text { Estimate }\end{array}$ & $\begin{array}{c}\text { Upper } \\
\text { Range }\end{array}$ \\
\hline \multirow{4}{*}{ Cost } & $\begin{array}{c}\text { Total Renewable } \\
\text { Electricity Generation Cost }\end{array}$ & $20,606.92$ & $24,348.04$ & $28,240.84$ \\
\cline { 2 - 5 } & $\begin{array}{c}\text { Compensation Cost for } \\
\text { Intermittent Technologies }\end{array}$ & $1,204.21$ & $2,024.66$ & $3,199.93$ \\
\cline { 2 - 5 } & Total Costs & $\mathbf{2 1 , 8 1 1 . 1 3}$ & $\mathbf{2 6 , 3 7 2 . 7 0}$ & $\mathbf{3 1 , 4 4 0 . 7 7}$ \\
\hline \multirow{4}{*}{ Benefit } & $\begin{array}{c}\text { Avoided Electricity } \\
\text { Generation Cost }\end{array}$ & $24,587.65$ & $27,559.86$ & $32,668.37$ \\
\cline { 2 - 5 } & $\begin{array}{c}\text { Human Health and } \\
\text { Environmental Benefits }\end{array}$ & $1,134.92$ & $16,880.68$ & $53,321.61$ \\
\cline { 2 - 5 } & $\begin{array}{c}\text { Avoided Cost of Other } \\
\text { Externalities }\end{array}$ & $1,304.32$ & $2,056.87$ & $6,974.67$ \\
\cline { 2 - 5 } & Total Benefits & $\mathbf{2 7 , 0 2 6 . 8 9}$ & $\mathbf{4 6 , 4 9 7 . 4 1}$ & $\mathbf{9 2 , 9 6 4 . 6 6}$ \\
\hline \multicolumn{2}{|c|}{ Net Present Value } & $\mathbf{5 , 2 1 5 . 7 6}$ & $\mathbf{2 0 , 1 2 4 . 7 1}$ & $\mathbf{6 1 , 5 2 3 . 8 9}$ \\
\hline
\end{tabular}

Source: Author's calculations.

Table 4.2: Net Present Value of a 25\% RPS in Michigan from 2016 to 2025 (Tax Credits Included Scenario) (Million 2011\$)

\begin{tabular}{|c|c|c|c|c|}
\hline & $\begin{array}{c}\text { Lower } \\
\text { Range }\end{array}$ & $\begin{array}{c}\text { Best } \\
\text { Estimate }\end{array}$ & $\begin{array}{c}\text { Upper } \\
\text { Range }\end{array}$ \\
\hline \multirow{4}{*}{ Cost } & $\begin{array}{c}\text { Total Renewable } \\
\text { Electricity Generation Cost }\end{array}$ & $14,148.75$ & $17,884.27$ & $21,762.97$ \\
\cline { 2 - 5 } & $\begin{array}{c}\text { Compensation Cost for } \\
\text { Intermittent Technologies }\end{array}$ & $1,204.21$ & $2,024.66$ & $3,199.93$ \\
\cline { 2 - 5 } & Total Costs & $\mathbf{1 5 , 3 5 2 . 9 6}$ & $\mathbf{1 9 , 9 0 8 . 9 3}$ & $\mathbf{2 4 , 9 6 2 . 9 0}$ \\
\hline \multirow{5}{*}{ Benefit } & $\begin{array}{c}\text { Avoided Electricity } \\
\text { Generation Cost }\end{array}$ & $24,587.65$ & $27,559.86$ & $32,668.37$ \\
\cline { 2 - 5 } & $\begin{array}{c}\text { Human Health and } \\
\text { Environmental Benefits }\end{array}$ & $1,134.92$ & $16,880.68$ & $53,321.61$ \\
\cline { 2 - 5 } & $\begin{array}{c}\text { Avoided Cost of Other } \\
\text { Externalities }\end{array}$ & $1,304.32$ & $2,056.87$ & $6,974.67$ \\
\cline { 2 - 5 } & Total Benefits & $\mathbf{2 7 , 0 2 6 . 8 9}$ & $\mathbf{4 6 , 4 9 7 . 4 1}$ & $\mathbf{9 2 , 9 6 4 . 6 6}$ \\
\hline \multicolumn{2}{|c|}{ Net Present Value } & $\mathbf{1 1 , 6 7 3 . 9 3}$ & $\mathbf{2 6 , 5 8 8 . 4 8}$ & $\mathbf{6 8 , 0 0 1 . 7 6}$ \\
\hline
\end{tabular}

Source: Author's calculations. 
2016 to 2025. Compared with the results in Table 4.1, if the TC policies do not change until 2025, a 25\% RPS can create about $\$ 6$ billion net present value to the State from the best estimate. The TCs play an important role in reducing the cost of implementing a $25 \%$ RPS. Thus, it is safe to conclude that a $25 \%$ RPS should be approved.

\subsection{Sensitivity Analysis}

The present value of a project changes significantly when using different discount rates. The sensitivity analysis can be used to test how sensitive the estimated net values are to various values of variables with uncertainty and to the assumed changes (Harrison 2010). The results of sensitivity analysis, which is applied to the change of discount, are shown in Table 4.3. The results in the Table 4.3 indicate that the results are not sensitive to the change of discount rate: the NPVs in all estimated ranges are positive with different discount rates. Even increasing the discount rate by $50 \%$, the NPVs of a $25 \%$ RPS from 2016 to 2025 are still positive.

Another variable to consider in sensitivity analysis is the share of solar energy generated to meet an RPS. Recall that Table 2.4 shows the projected renewable electricity sales in Michigan based on the EIA's estimation. According to the EIA's 2013 AEO, electricity generation from solar energy has the highest annual increase rate $(9.8 \%)$ among other renewable sources. However, the proportion of the electricity sales from solar energy among the ones generated from other renewable sources is very small, which is about $0.5 \%$ annually. The reason for its "high growth rate but annual low proportion" is that only a small amount of electricity is generated from solar energy at the beginning 
Table 4.3: Sensitivity Analysis for Net Present Value of a 25\% RPS in Michigan from 2016 to 2025 With a Change of Discount Rate (r) (Million 2011\$)

\begin{tabular}{|c|c|c|c|c|}
\hline \multicolumn{5}{|c|}{ Best Estimate } \\
\hline Assumption & $\mathbf{r = 0 . 1 \%}$ & $\mathbf{r}=\mathbf{0 . 1 1 \%}$ & $\mathbf{r = 0 . 0 9 \%}$ & $\mathbf{r = 0 . 1 5 \%}$ \\
\hline NPV (Without TCs) & $20,124.71$ & $20,106.60$ & $20,142.85$ & $20,034.32$ \\
\hline NPV (With TCs) & $26,588.48$ & $26,564.54$ & $26,612.45$ & $26,469.01$ \\
\hline \multicolumn{5}{|c|}{ Lower Range } \\
\hline Assumption & $\mathbf{r = 0 . 1 \%}$ & $\mathbf{r}=\mathbf{0 . 1 1 \%}$ & $\mathbf{r = 0 . 0 9 \%}$ & $\mathbf{r}=\mathbf{0 . 1 5 \%}$ \\
\hline NPV (Without TCs) & $5,215.76$ & $5,211.08$ & $5,220.43$ & $5,192.44$ \\
\hline NPV (With TCs) & $11,673.93$ & $11,663.43$ & $11,684.43$ & $11,621.56$ \\
\hline \multicolumn{5}{|c|}{ Upper Range } \\
\hline Assumption & $\mathbf{r = 0 . 1 \%}$ & $\mathbf{r}=\mathbf{0 . 1 1 \%}$ & $\mathbf{r = 0 . 0 9 \%}$ & $\mathbf{r = 0 . 1 5 \%}$ \\
\hline NPV (Without TCs) & $61,523.89$ & $61,468.44$ & $61,579.39$ & $61,247.25$ \\
\hline NPV (With TCs) & $68,001.76$ & $67,940.47$ & $68,063.11$ & $67,695.98$ \\
\hline
\end{tabular}

Source: Author's calculations.

of the projected period. For example, in 2012, the electricity sales from solar energy was about $43.49 \mathrm{MWh}$, which only accounted for $1 \%$ of total renewable electricity sales in that year. Assuming a more progressive role of solar energy in generating electricity in Michigan in the future and testing its influences on the present value of a $25 \%$ RPS, the sensitivity test is conducted against different growth rates of electricity produced from solar energy. Keeping other assumptions constant, the results of the sensitivity analysis for the change of growth rate of electricity generation from solar energy are presented in Table 4.4 .

The right two columns in Table 4.4 indicate the proportion of projected electricity sales from wind and solar energy among the total renewable electricity sales in 2025 in Michigan. In this sensitivity analysis $80 \%$ is chosen as the cap of the growth rate is 
Table 4.4: Sensitivity Analysis for Net Present Value of a 25\% RPS in Michigan from 2016 to 2025 With a Change of Growth Rate (g) of Electricity Generation from Solar Energy (Million 2011\$)

\begin{tabular}{|c|c|c|c|c|c|}
\hline $\begin{array}{c}\text { Annual } \\
\text { Growth Rate }\end{array}$ & $\begin{array}{c}\text { Lower } \\
\text { Range }\end{array}$ & $\begin{array}{c}\text { Best } \\
\text { Estimate }\end{array}$ & $\begin{array}{c}\text { Upper } \\
\text { Range }\end{array}$ & $\begin{array}{c}\text { Wind/Total } \\
\text { in 2025 }\end{array}$ & $\begin{array}{c}\text { Solar/Total } \\
\text { in 2025 }\end{array}$ \\
\hline $\begin{array}{c}\mathbf{g = 9 . 8 \%} \\
\text { (Original) }\end{array}$ & $5,215.76$ & $20,124.71$ & $61,523.89$ & $87.51 \%$ & $0.51 \%$ \\
\hline $\mathbf{g = 5 0 \%}$ & $3,694.59$ & $18,172.32$ & $57,205.97$ & $76.39 \%$ & $11.63 \%$ \\
\hline $\mathbf{g = 7 0 \%}$ & 533.68 & $14,115.93$ & $48,237.11$ & $47.35 \%$ & $40.67 \%$ \\
\hline $\mathbf{g = 8 0 \%}$ & $(2,595.14)$ & $10,100.93$ & $39,360.55$ & $15.99 \%$ & $72.03 \%$ \\
\hline
\end{tabular}

Source: Author's calculations.

because when the growth rate is greater than $84 \%$, the electricity sales from wind energy will be negative in 2025 , which cannot happen. From the sensitivity analysis one can conclude that except for the negative value in the lower range of present value of a $25 \%$ RPS when the annual grow rate is an unlikely $80 \%$, all the other NPVs are positive with different growth rates. The results in the Table 4.4 indicate that the results are not sensitive to the change of growth rate of electricity generated from solar energy.

\subsection{Limitation and the Implication for Future Studies}

Although the results indicate that a 25\% RPS should be implemented for the reason that it can generate positive benefits for the State of Michigan, one should be cautious about the potential limitations of the study.

First, limitations originate from using the national figures to project future electricity demand. If the future trend of electricity sales in Michigan does not match or even contradicts the national trend, the results will be seriously biased. To be more 
confident in projecting the future, professional software can be applied for fulfilling this purpose.

Another potential problem stems from using LECs to calculate the electricity generation cost. The national average figure is adopted in the thesis to estimate the cost of different technology-based power plants. LECs for different kinds of power plants vary from state to state. Although by considering the cost varieties in different regions EIA provides the ranges of LECs for different power plants, the best estimate of the cost of renewable electricity generation may be biased if the difference is large between the national average figure and that in Michigan. If Michigan data are available, the results can be more precise.

When calculating the air pollutant emissions, this thesis includes only the emissions of the selected criteria air pollutants and their negative impacts on human health and the environment. Additional pollutants such as lead and other heavy metals are excluded from the benefits calculation, since compared with the selected pollutants, their amounts can be neglected in spite of the fact that the benefit per unit avoided emission is very large. For example, according to Spath et al. (1999), average lead emissions per $\mathrm{kWh}$ of net electricity produced from coal in the U.S. is $3.00 \times 10^{-5} \mathrm{~kg}$, which is more than $10^{5}$ times smaller than $\mathrm{NO}_{\mathrm{x}}$ emission $(3.35 \mathrm{~kg} / \mathrm{kWh})$. Although the average damage cost per unit of lead emission $(\$ 1,637 /$ ton $)$ is about 200 times larger than $\mathrm{NO}_{\mathrm{x}}(\$ 85 /$ ton $)$ (Banzhaf et al. 1996), its benefits are not taken into account when considering that lead emissions are much smaller compared to other pollutants, the emissions of which are calculated in this thesis. Also, the social cost of GHGs, other than $\mathrm{CO}_{2}$, emissions are not included. If these benefits are taken into account, the benefits under a 25\% RPS will be 
much larger. Furthermore, according to Banzhaf et al. (1996), the damage cost will be higher if the secondary particulate formation from $\mathrm{SO}_{2}$ and $\mathrm{NO}_{\mathrm{x}}$ are considered. Including the secondary pollutant formation from $\mathrm{SO}_{2}$ and $\mathrm{NO}_{\mathrm{x}}$ would add even more benefits to the final results.

The proponents of advocating a higher RPS often state that more green jobs can be provided by investing more in renewable energy projects. According to Zycher (2011), the created employment from renewable policies would ironically be a cost for the whole economy, for the reason that the scarce labor used for the renewable energy projects would not available for productive activity in other places. Moreover, in the short run, the creation of green jobs may cause the loss of jobs in other sectors, and Zycher (2011) argues that in the long run the employment only shifts among economic sectors. Thus, the benefits of job creation from renewable energy projects are not included in the benefits calculation in this thesis. Future studies can utilize advanced methods to study the net impact of a $25 \%$ RPS on local employment and other economic factors in Michigan.

Finally, even if Michigan has the technical potential to expand its current renewable electricity generation to fulfill a $25 \%$ RPS and a $25 \%$ RPS passes the costbenefit analysis test, why was Proposal 3 defeated? Jacobson and Delucchi (2011) examined the feasibility of powering the world by a wind, water and the sun (WWS) electricity system. They concluded that the WWS energy system can achieve $30 \%$ power demand worldwide; and the footprint and spacing area possesses only $0.74 \%$ and $1.16 \%$ of global land area. Also, they pointed out that the obstacles of fully converting to this energy system are social and political, not technological or even economic (Delucchi and Jacobson 2011). Here are some possible reasons for the defeat of Proposal 3 from 
political and social perspectives: The opponents raised more than $\$ 25$ million, which is about twice the money that the supporters contributed to the campaign, to defeat the proposal through negative advertising ${ }^{26}$. Another reason originates from the public concern of changing the State Constitution. The failure of Proposal 3 does not mean that renewable energy is not favored by Michiganders. According to the American Wind Energy Association, one poll result on the 2012 Michigan Election Day indicated that only $1 \%$ of voters who rejected the amendment did so because they opposed expanded renewable energy in the State. Sixty percent of voters opposed the proposal for the reason that they didn't want the State Constitution to mandate $i^{27}$. If this is true, the policy makers can craft relevant legislation and regulations to increase the public acceptance of a 25\% RPS in Michigan in the future.

In spite of the above limitations, the methods and the analysis procedures in this thesis can still contribute to the future study and research on similar issues in other states in the U.S. A higher RPS is not favored by the utilities mostly because they are unwilling to invest in renewable electricity generation projects, which are currently more expensive than other electricity production technologies. Even with the uncertainty of future policies, which can promote the development of renewable energy projects and reduce the cost (like PTCs for renewable electricity generation projects), they are reluctant to expand the current electricity generation capacity from renewable energy resources. The possible increase in electricity bills is one major reason that most electricity customers do

\footnotetext{
${ }^{26} \mathrm{See}$ http://www.mcfn.org/pdfs/reports/Prop3_final.pdf. Retrieved on October 14, 2013.

${ }^{27}$ See http://www.awea.org/blog/index.cfm?customel_dataPageID_1699=19642. Retrieved on May 7, 2013.
} 
not prefer a higher RPS. However, based on the analysis in this thesis, huge human health and environmental benefits can be gained from an RPS, which are not usually quantitatively discussed in other studies. Not only private benefits but also these social benefits should be taken into consideration to have a full picture of the impacts of an RPS. 


\section{References}

Alsema, E.A.(2000). Energy Pay-Back Time and $\mathrm{CO}_{2}$ emissions of PV Systems. Progress in Photovoltaics: Research and Applications 8, 17-25.

American Wind Energy Association (AWEA). (2011). Wind Power Outlook 2011. Washington, D.C. Retrieved from: http://www.awea.org/_cs_upload/learnabout/publications/reports/8546_1.pdf.

Banzhaf, H. S., Desvousges, W. H., \& Johnson, F. R. (1996). Assessing the Externalities of Electricity Generation in the Midwest. Resource and Energy Economics, 18(4), 395421.

Barradale, M. J. (2010). Impact of Public Policy Uncertainty on Renewable Energy Investment: Wind Power and the Production Tax Credit. Energy Policy 38(12): 76987709.

Baumol, W. J. and W. E. Oates (1988). The Theory of Environmental Policy. Cambridge: Cambridge University Press.

Borenstein, S. (2012). The Private and Public Economics of Renewable Electricity Generation. The Journal of Economic Perspectives, 26(1), 67-92.

Burtraw, D., Krupnick, A., Mansur, E., Austin, D., \& Farrell, D. (1998). Costs and Benefits of Reducing Air Pollutants Related to Acid Rain. Contemporary Economic Policy, 16(4), 379-400.

Calnin, B., McKeown, C., Miller, S. (2012). Projected Job and Investment Impacts of Policy Requiring 25\% Renewable Energy by 2025 in Michigan. East Lansing, MI: Michigan State University.

Chestnut, L. G., \& Mills, D. M. (2005). A Fresh Look at the Benefits and Costs of the US Acid Rain Program. Journal of Environmental Management, 77(3), 252-266.

Database of State Incentives for Renewable Energy (DSIRE) (2013). Webpage. Retrieved from: http://dsireusa.org/incentives/incentive.cfm?Incentive_Code=US13F

Delucchi, M. A., \& Jacobson, M. Z. (2011). Providing All Global Energy with Wind, Water, and Solar Power, Part II: Reliability, System and Transmission Costs, and Policies. Energy Policy, 39(3), 1170-1190.

Energy Information Administration (EIA) (2010). Annual Energy Outlook 2010 DOE/EIA-0383(2010). US Department of Energy. Washington, DC.

Energy Information Administration (EIA) (2011). Annual Energy Outlook 2011 DOE/EIA-0383(2011). US Department of Energy. Washington, DC. 
Energy Information Administration (EIA) (2012). Annual Energy Outlook 2012 DOE/EIA-0383(2012). US Department of Energy. Washington, DC.

Energy Information Administration EIA (2013). Annual Energy Outlook 2013 DOE/EIA-0383(2013). US Department of Energy. Washington, DC.

Epstein, P. R., Buonocore, J. J., Eckerle, K., Hendryx, M., Stout III, B. M., Heinberg, R., Clapp, R. W., May, B., Reinhart, N. L., Ahern, M. M., Doshi, S. K.\& Glustrom, L. (2011). Full Cost Accounting for the Life Cycle of Coal. Annals of the New York Academy of Sciences, 1219(1), 73-98.

Fann, N., Fulcher, C. M., \& Hubbell, B. J. (2009). The Influence of Location, Source, and Emission Type in Estimates of the Human Health Benefits of Reducing a Ton of Air Pollution. Air Quality, Atmosphere \& Health, 2(3), 169-176.

Ford, R., \& Milborrow, D. (2005). Integrating Renewables. British Wind Energy Association. http:/w. bwea. com/pdf/RAEInternational. pdf.

Gagnon, L., Belanger, C., \& Uchiyama, Y. (2002). Life-Cycle Assessment of Electricity Generation Options: the Status of Research in Year 2001. Energy Policy, 30(14), 12671278.

Gross, R. (2006). The Costs and Impacts Of Intermittency: an Assessment of the Evidence on the Costs and Impacts of Intermittent Generation on the British Electricity Network. UK Energy Research Centre, London.

Hanley, N. and E. Barbier (2009). Pricing Nature: Cost-Benefit Analysis and Environmental Policy, Cheltenham, UK·Northampton, MA, U.S.: Edward Elgar Publishing.

Harrison, M. (2010). Valuing the Future: the Social Discount Rate in Cost-Benefit Analysis. Melbourne, Australia: Productivity Commission.

Heller, M. C., Keoleian, G. A., Mann, M. K., \& Volk, T. A. (2004). Life Cycle Energy and Environmental Benefits of Generating Electricity from Willow Biomass. Renewable Energy, 29(7), 1023-1042.

Jacobson, M. Z., \& Delucchi, M. A. (2011). Providing All Global Energy with Wind, Water, and Solar Power, Part I: Technologies, Energy Resources, Quantities and Areas of Infrastructure, and Materials. Energy Policy, 39(3), 1154-1169.

Johnson, N. H. (2009). A Cost-Benefit Analysis for a Proposed Wind Turbine at Principia College (Unpublished Master's Report). Michigan Technological University, Houghton, MI.

Joskow, P. L. (2011). Comparing the Costs of Intermittent and Dispatchable Electricity Generating Technologies. The American Economic Review 101(3): 238-241. 
Kammen, D. M. and S. Pacca (2004). Assessing the Costs of Electricity. Annual Review of Environment and Resources 29(1): 301-344.

Lopez, A., Roberts, B., Heimiller, D., Blair, N., \& Porro, G. (2012). US Renewable Energy Technical Potentials: A GIS-Based Analysis (NO.NREL/TP-6A20-51946A). Golden, CO, U.S.: National Renewable Energy Laboratory. Retrieved from: http://blogsimages.forbes.com/davidferris/files/2012/08/51946.pdf.

Manville, A. and M. Albert (2005). Bird Strikes and Electrocutions at Power Lines, Communication Towers, and Wind Turbines: State of the Art and State of the ScienceNext Steps Toward Mitigation. USDA Forest Service General Technical Report PSWGTR-191, Washington DC.

Michigan Public Service Comission (MPSC) (2011). Michigan Energy Overview 2011. Lansing, MI. Retrieved from:

http://www.dleg.state.mi.us/mpsc/reports/energy/energyoverview/michigan_energy_over view.pdf.

Michigan Public Service Comission (MPSC) (2013). Report on the Implementation of the P.A. 295 Renewable Energy Standard and the Cost-Effectiveness of the Energy

Standards. Lansing, MI. Avaialble at

http://www.michigan.gov/documents/mpsc/implementation_of_PA295_renewable_energ y_411615_7.pdf.

Moyer, E., Johnson, S., Goldberger, L., \& Zhu, J. (2012). Feasibility and Implications of the Michigan 2012 Proposal 3 for a 25\% State Renewable Portfolio Standard. Chicago:

University of Chicago.

Office of Management and Budget (OMB). 2012. Discount Rates for Cost -Effectiveness, Lease Purchase, and Related Analyses. OMB Circular No. A-94. Executive Office of the President. Retrieved from:

http://www.whitehouse.gov/sites/default/files/omb/memoranda/2013/m-13-04.pdf.

Pachauri, R. K., \& Reisinger, A. (2007). Climate Change 2007: Synthesis Report. Contribution of Working Groups I, II and III to the Fourth Assessment Report of the Intergovernmental Panel on Climate Change. Geneva, Switzerland: Intergovernmental Panel on Climate Change (IPCC).

Palmer, K. and D. Burtraw (2005). Cost-effectiveness of Renewable Electricity Policies. Energy Economics 27(6): 873-894.

Pehnt, M. (2006). Dynamic Life Cycle Assessment (LCA) of Renewable Energy Technologies. Renewable Energy 31(1): 55-71.

Roth, I. F. and L. L. Ambs (2004). Incorporating Externalities into a Full Cost Approach to Electric Power Generation Life-Cycle Costing. Energy 29(12): 2125-2144. 
Schleisner, L. (2000). Life Cycle Assessment of a Wind Farm and Related Externalities. Renewable Energy 20(3): 279-288.

Sovacool, B. K. (2008). Renewable Energy: Economically Sound, Politically Difficult. The Electricity Journal 21(5): 18-29.

Spath, P. L., Mann, M. K., \& Kerr, D. R. (1999). Life Cycle Assessment of Coal-Fired Power Production (No. NREL/TP-570-25119). National Renewable Energy Laboratory. Golden, CO.

Spath, P. L. and Mann, M. K. (2000). Life Cycle Assessment of a Natural Gas Combined-Cycle Power Generation System (No. NREL/TP-570-27715). Golden, CO: National Renewable Energy Laboratory.

Sueyoshi, T., Goto, M., \& Ueno, T. (2010). Performance Analysis of US Coal-Fired Power Plants by Measuring Three DEA Efficiencies. Energy Policy, 38(4), 1675-1688.

Sundqvist, T. (2004). What Causes the Disparity of Electricity Externality Estimates? Energy Policy 32(15): 1753-1766.

The Business Council for Sustainable Energy (BCSE) (2013). Sustainable Energy in America 2013 Factbook. Bloomberg Finance. New York, NY. Retrieved from: http://www.bcse.org/factbook/pdfs/BCSE_BNEF_Sustainable_Energy_in_America_2013 _Factbook.pdf.

Tuerck, D. G., Bachman, P., \&Head, M. (2012). The Projected Economic Impact of Proposal 3 and Michigan's Renewable Energy Standard (ISBN: 978-0-9883921-0-6 S2012-07). Midland, MI: Mackinac Center for Public Policy. Retrieved from: http://www.mackinac.org/archives/2012/25X25STUDY.pdf.

Utility Wind Interest Group (UWIG) (2003) Wind Power Impacts on Electric-PowerSystem Operating Costs, Summary and Perspective on Work Done to Date, November 2003. Reston, VA. Retrieved from: http://www.uwig.org/UWIGOpImpFinal11-03.pdf.

Wiser, R. (2007). Wind Power and the Production Tax Credit: An Overview of Research Results. Testimony before the Senate Finance Committee. Washington, DC.

Wiser, R., Namovicz, C., Gielecki, M., \& Smith, R.(2008). Renewables Portfolio Standards: A Factual Introduction to Experience from the United States. Berkeley, CA: Lawrence Berkeley National Laboratory. Retrieved from: http://escholarship.org/uc/item/9wr9062r

Yin, H. and N. Powers (2010). Do state renewable portfolio standards promote in-state renewable generation?. Energy Policy 38(2): 1140-1149.

Zycher, Benjamin (2011). Renewable Energy Sources for Electricity Generation: Economic Analysis and Outlook. Washington, D.C., U.S.: Rowman \& Littlefield. 


\section{Appendix $^{28}$}

Table A1: Minimum LECs for Selected Power Plant Technologies in the U.S. (2011\$/MWh)

\begin{tabular}{|c|c|c|c|c|c|c|}
\hline Year & $\begin{array}{c}\text { Conventional } \\
\text { Coal }\end{array}$ & $\begin{array}{c}\text { Natural Gas- } \\
\text { fired (Advanced } \\
\text { Combined } \\
\text { Cycle) }\end{array}$ & $\begin{array}{c}\text { Solar } \\
\text { PV }\end{array}$ & Biomass & $\begin{array}{c}\text { Landfill } \\
\text { Gas }\end{array}$ & $\begin{array}{c}\text { Wind } \\
\text { (Onshore) }\end{array}$ \\
\hline $\mathbf{2 0 1 6}$ & 89.5 & 60 & 112.5 & 98 & 41.5 & 73.5 \\
\hline $\mathbf{2 0 1 7}$ & 89.5 & 60 & 112.5 & 98 & 41.5 & 73.5 \\
\hline $\mathbf{2 0 1 8}$ & 89.5 & 60 & 112.5 & 98 & 41.5 & 73.5 \\
\hline $\mathbf{2 0 1 9}$ & 89.5 & 60 & 112.5 & 98 & 41.5 & 73.5 \\
\hline $\mathbf{2 0 2 0}$ & 89.5 & 60 & 112.5 & 98 & 41.5 & 73.5 \\
\hline $\mathbf{2 0 2 1}$ & 88.6 & 60.8 & 111.9 & 97.1 & 40.6 & 72.9 \\
\hline $\mathbf{2 0 2 2}$ & 87.7 & 61.6 & 111.3 & 96.2 & 39.7 & 72.3 \\
\hline $\mathbf{2 0 2 3}$ & 86.8 & 62.4 & 110.7 & 95.3 & 38.8 & 71.7 \\
\hline $\mathbf{2 0 2 4}$ & 85.9 & 63.2 & 110.1 & 94.4 & 37.9 & 71.1 \\
\hline $\mathbf{2 0 2 5}$ & 85 & 64 & 109.5 & 93.5 & 37 & 70.5 \\
\hline
\end{tabular}

Table A2: Maximum LECs for Selected Power Plant Technologies in the U.S. (2011\$/MWh)

\begin{tabular}{|c|c|c|c|c|c|c|}
\hline Year & $\begin{array}{c}\text { Conventional } \\
\text { Coal }\end{array}$ & $\begin{array}{c}\text { Natural Gas- } \\
\text { fired (Advanced } \\
\text { Combined } \\
\text { Cycle) }\end{array}$ & $\begin{array}{c}\text { Solar } \\
\text { PV }\end{array}$ & Biomass & $\begin{array}{c}\text { Landfill } \\
\text { Gas }\end{array}$ & $\begin{array}{c}\text { Wind } \\
\text { (Onshore) }\end{array}$ \\
\hline $\mathbf{2 0 1 6}$ & 118.3 & 76.1 & 224.4 & 130.8 & 81.8 & 99.8 \\
\hline $\mathbf{2 0 1 7}$ & 118.3 & 76.1 & 224.4 & 130.8 & 81.8 & 99.8 \\
\hline $\mathbf{2 0 1 8}$ & 118.3 & 76.1 & 224.4 & 130.8 & 81.8 & 99.8 \\
\hline $\mathbf{2 0 1 9}$ & 118.3 & 76.1 & 224.4 & 130.8 & 81.8 & 99.8 \\
\hline $\mathbf{2 0 2 0}$ & 118.3 & 76.1 & 224.4 & 130.8 & 81.8 & 99.8 \\
\hline $\mathbf{2 0 2 1}$ & 117.4 & 76.9 & 223.8 & 129.9 & 80.9 & 99.2 \\
\hline $\mathbf{2 0 2 2}$ & 116.5 & 77.7 & 223.2 & 129 & 80 & 98.6 \\
\hline $\mathbf{2 0 2 3}$ & 115.6 & 78.5 & 222.6 & 128.1 & 79.1 & 98 \\
\hline $\mathbf{2 0 2 4}$ & 114.7 & 79.3 & 222 & 127.2 & 78.2 & 97.4 \\
\hline $\mathbf{2 0 2 5}$ & 113.8 & 80.1 & 221.4 & 126.3 & 77.3 & 96.8 \\
\hline
\end{tabular}

${ }^{28}$ Unless otherwise noted, the sources for all the tables in the Appendix are from author's calculations. 
Table A3: The Lower Range for the Present Value of the Additional Cost of Renewable Electricity Generation due to a 25\% RPS in Michigan (Million 2011\$)

\begin{tabular}{|c|c|c|c|c|c|}
\hline Year & $\begin{array}{c}\text { Before } \\
\text { Discounting }\end{array}$ & $\mathbf{r}=\mathbf{0 . 1 0} \%$ & $\mathbf{r}=\mathbf{0 . 1 1} \%$ & $\mathbf{r}=\mathbf{0 . 0 9 \%}$ & $\mathbf{r}=\mathbf{0 . 1 5 \%}$ \\
\hline $\mathbf{2 0 1 6}$ & 370.39 & 369.28 & 369.17 & 369.39 & 368.72 \\
\hline $\mathbf{2 0 1 7}$ & 745.73 & 742.76 & 742.46 & 743.06 & 741.28 \\
\hline $\mathbf{2 0 1 8}$ & $1,126.10$ & $1,120.48$ & $1,119.92$ & $1,121.04$ & $1,117.69$ \\
\hline $\mathbf{2 0 1 9}$ & $1,511.52$ & $1,502.49$ & $1,501.59$ & $1,503.39$ & $1,497.99$ \\
\hline $\mathbf{2 0 2 0}$ & $1,902.07$ & $1,888.81$ & $1,887.49$ & $1,890.13$ & $1,882.22$ \\
\hline $\mathbf{2 0 2 1}$ & $2,279.02$ & $2,260.87$ & $2,259.07$ & $2,262.68$ & $2,251.86$ \\
\hline $\mathbf{2 0 2 2}$ & $2,654.66$ & $2,630.89$ & $2,628.53$ & $2,633.26$ & $2,619.09$ \\
\hline $\mathbf{2 0 2 3}$ & $3,028.92$ & $2,998.80$ & $2,995.80$ & $3,001.79$ & $2,983.86$ \\
\hline $\mathbf{2 0 2 4}$ & $3,401.72$ & $3,364.53$ & $3,360.83$ & $3,368.23$ & $3,346.10$ \\
\hline $\mathbf{2 0 2 5}$ & $3,773.01$ & $3,728.02$ & $3,723.56$ & $3,732.49$ & $3,705.75$ \\
\hline Total & N/A & $20,606.92$ & $20,588.41$ & $20,625.45$ & $20,514.55$ \\
\hline
\end{tabular}

Table A4: The Upper Range for the Present Value of Additional Cost of Renewable Electricity Generation due to a 25\% RPS in Michigan (Million 2011\$)

\begin{tabular}{|c|c|c|c|c|c|}
\hline Year & $\begin{array}{c}\text { Before } \\
\text { Discounting }\end{array}$ & $\mathbf{r}=\mathbf{0 . 1 0} \%$ & $\mathbf{r}=\mathbf{0 . 1 1} \%$ & $\mathbf{r}=\mathbf{0 . 0 9 \%}$ & $\mathbf{r}=\mathbf{0 . 1 5 \%}$ \\
\hline $\mathbf{2 0 1 6}$ & 504.41 & 502.90 & 502.75 & 503.05 & 502.14 \\
\hline $\mathbf{2 0 1 7}$ & $1,015.71$ & $1,011.66$ & $1,011.26$ & $1,012.06$ & $1,009.64$ \\
\hline $\mathbf{2 0 1 8}$ & $1,534.00$ & $1,526.36$ & $1,525.59$ & $1,527.12$ & $1,522.55$ \\
\hline $\mathbf{2 0 1 9}$ & $2,059.37$ & $2,047.05$ & $2,045.83$ & $2,048.28$ & $2,040.93$ \\
\hline $\mathbf{2 0 2 0}$ & $2,591.90$ & $2,573.83$ & $2,572.03$ & $2,575.63$ & $2,564.85$ \\
\hline $\mathbf{2 0 2 1}$ & $3,112.93$ & $3,088.13$ & $3,085.67$ & $3,090.60$ & $3,075.82$ \\
\hline $\mathbf{2 0 2 2}$ & $3,634.77$ & $3,602.22$ & $3,598.99$ & $3,605.46$ & $3,586.07$ \\
\hline $\mathbf{2 0 2 3}$ & $4,157.42$ & $4,116.07$ & $4,111.96$ & $4,120.18$ & $4,095.57$ \\
\hline $\mathbf{2 0 2 4}$ & $4,680.84$ & $4,629.66$ & $4,624.57$ & $4,634.75$ & $4,604.29$ \\
\hline $\mathbf{2 0 2 5}$ & $5,205.02$ & $5,142.97$ & $5,136.81$ & $5,149.14$ & $5,112.24$ \\
\hline Total & N/A & $28,240.84$ & $28,215.44$ & $28,266.27$ & $28,114.10$ \\
\hline
\end{tabular}


Table A5: The Lower Range for the Cost of Renewable Electricity Generation Under a 25\% RPS in Michigan (Million 2011\$)

\begin{tabular}{|c|c|c|c|c|c|}
\hline Year & Total & Solar PV & Biomass & Landfill Gas & Wind (Onshore) \\
\hline $\mathbf{2 0 1 6}$ & $\mathbf{2 , 6 0 0 . 3 9}$ & 30.79 & 238.65 & 33.04 & $2,297.90$ \\
\hline $\mathbf{2 0 1 7}$ & $\mathbf{2 , 9 9 1 . 1 4}$ & 33.81 & 249.39 & 33.37 & $2,674.57$ \\
\hline $\mathbf{2 0 1 8}$ & $\mathbf{3 , 3 8 7 . 0 1}$ & 37.13 & 260.62 & 33.70 & $3,055.57$ \\
\hline $\mathbf{2 0 1 9}$ & $\mathbf{3 , 7 8 8 . 0 6}$ & 40.76 & 272.34 & 34.04 & $3,440.92$ \\
\hline $\mathbf{2 0 2 0}$ & $\mathbf{4 , 1 9 4 . 3 5}$ & 44.76 & 284.60 & 34.38 & $3,830.61$ \\
\hline $\mathbf{2 0 2 1}$ & $\mathbf{4 , 5 6 7 . 6 8}$ & 48.88 & 294.67 & 33.97 & $4,190.15$ \\
\hline $\mathbf{2 0 2 2}$ & $\mathbf{4 , 9 3 9 . 5 5}$ & 53.39 & 305.08 & 33.55 & $4,547.53$ \\
\hline $\mathbf{2 0 2 3}$ & $\mathbf{5 , 3 0 9 . 8 7}$ & 58.30 & 315.83 & 33.12 & $4,902.62$ \\
\hline $\mathbf{2 0 2 4}$ & $\mathbf{5 , 6 7 8 . 5 8}$ & 63.67 & 326.92 & 32.67 & $5,255.31$ \\
\hline $\mathbf{2 0 2 5}$ & $\mathbf{6 , 0 4 5 . 6 0}$ & 69.53 & 338.38 & 32.22 & $5,605.48$ \\
\hline
\end{tabular}

Table A6: The Upper Range for the Cost of Renewable Electricity Generation Under a 25\% RPS in Michigan (Million 2011\$)

\begin{tabular}{|c|c|c|c|c|c|}
\hline Year & Total & Solar PV & Biomass & Landfill Gas & Wind (Onshore) \\
\hline $\mathbf{2 0 1 6}$ & $\mathbf{3 , 5 6 5 . 2 2}$ & 61.42 & 318.53 & 65.12 & $3,120.15$ \\
\hline $\mathbf{2 0 1 7}$ & $\mathbf{4 , 0 9 7 . 6 7}$ & 67.44 & 332.86 & 65.78 & $3,631.59$ \\
\hline $\mathbf{2 0 1 8}$ & $\mathbf{4 , 6 3 7 . 2 5}$ & 74.05 & 347.84 & 66.43 & $4,148.92$ \\
\hline $\mathbf{2 0 1 9}$ & $\mathbf{5 , 1 8 4 . 0 6}$ & 81.31 & 363.49 & 67.10 & $4,672.16$ \\
\hline $\mathbf{2 0 2 0}$ & $\mathbf{5 , 7 3 8 . 1 9}$ & 89.28 & 379.85 & 67.77 & $5,201.29$ \\
\hline $\mathbf{2 0 2 1}$ & $\mathbf{6 , 2 6 1 . 5 0}$ & 97.77 & 394.21 & 67.69 & $5,701.82$ \\
\hline $\mathbf{2 0 2 2}$ & $\mathbf{6 , 7 8 5 . 5 1}$ & 107.06 & 409.10 & 67.61 & $6,201.75$ \\
\hline $\mathbf{2 0 2 3}$ & $\mathbf{7 , 3 1 0 . 2 1}$ & 117.24 & 424.53 & 67.52 & $6,700.93$ \\
\hline $\mathbf{2 0 2 4}$ & $\mathbf{7 , 8 3 5 . 5 7}$ & 128.38 & 440.51 & 67.42 & $7,199.26$ \\
\hline $\mathbf{2 0 2 5}$ & $\mathbf{8 , 3 6 1 . 5 7}$ & 140.58 & 457.08 & 67.31 & $7,696.61$ \\
\hline
\end{tabular}


Table A7: The Lower Range for the Cost of Renewable Electricity Generation Under the Current 10\% RES in Michigan (Million 2011\$)

\begin{tabular}{|c|c|c|c|c|c|}
\hline Year & Total & Solar PV & Biomass & Landfill Gas & Wind (Onshore) \\
\hline $\mathbf{2 0 1 6}$ & $\mathbf{2 , 2 3 0 . 0 0}$ & 28.24 & 229.95 & 32.94 & $1,938.87$ \\
\hline $\mathbf{2 0 1 7}$ & $\mathbf{2 , 2 4 5 . 4 1}$ & 28.43 & 231.54 & 33.17 & $1,952.26$ \\
\hline $\mathbf{2 0 1 8}$ & $\mathbf{2 , 2 6 0 . 9 2}$ & 28.63 & 233.14 & 33.40 & $1,965.75$ \\
\hline $\mathbf{2 0 1 9}$ & $\mathbf{2 , 2 7 6 . 5 4}$ & 28.83 & 234.75 & 33.63 & $1,979.33$ \\
\hline $\mathbf{2 0 2 0}$ & $\mathbf{2 , 2 9 2 . 2 7}$ & 29.03 & 236.37 & 33.86 & $1,993.01$ \\
\hline $\mathbf{2 0 2 1}$ & $\mathbf{2 , 2 8 8 . 6 6}$ & 29.07 & 235.82 & 33.35 & $1,990.41$ \\
\hline $\mathbf{2 0 2 2}$ & $\mathbf{2 , 2 8 4 . 8 8}$ & 29.12 & 235.25 & 32.84 & $1,987.67$ \\
\hline $\mathbf{2 0 2 3}$ & $\mathbf{2 , 2 8 0 . 9 5}$ & 29.16 & 234.66 & 32.32 & $1,984.81$ \\
\hline $\mathbf{2 0 2 4}$ & $\mathbf{2 , 2 7 6 . 8 5}$ & 29.20 & 234.05 & 31.79 & $1,981.81$ \\
\hline $\mathbf{2 0 2 5}$ & $\mathbf{2 , 2 7 2 . 6 0}$ & 29.24 & 233.43 & 31.25 & $1,978.68$ \\
\hline
\end{tabular}

Table A8: The Upper Range for the Cost of Renewable Electricity Generation Under the Current 10\% RES in Michigan (Million 2011\$)

\begin{tabular}{|c|c|c|c|c|c|}
\hline Year & Total & Solar PV & Biomass & Landfill Gas & Wind (Onshore) \\
\hline $\mathbf{2 0 1 6}$ & $\mathbf{3 , 0 6 0 . 8 2}$ & 56.33 & 306.92 & 64.92 & $2,632.65$ \\
\hline $\mathbf{2 0 1 7}$ & $\mathbf{3 , 0 8 1 . 9 6}$ & 56.72 & 309.04 & 65.37 & $2,650.83$ \\
\hline $\mathbf{2 0 1 8}$ & $\mathbf{3 , 1 0 3 . 2 5}$ & 57.11 & 311.17 & 65.82 & $2,669.14$ \\
\hline $\mathbf{2 0 1 9}$ & $\mathbf{3 , 1 2 4 . 6 9}$ & 57.50 & 313.32 & 66.28 & $2,687.59$ \\
\hline $\mathbf{2 0 2 0}$ & $\mathbf{3 , 1 4 6 . 2 9}$ & 57.90 & 315.49 & 66.74 & $2,706.16$ \\
\hline $\mathbf{2 0 2 1}$ & $\mathbf{3 , 1 4 8 . 5 7}$ & 58.15 & 315.48 & 66.46 & $2,708.48$ \\
\hline $\mathbf{2 0 2 2}$ & $\mathbf{3 , 1 5 0 . 7 4}$ & 58.39 & 315.46 & 66.17 & $2,710.71$ \\
\hline $\mathbf{2 0 2 3}$ & $\mathbf{3 , 1 5 2 . 8 0}$ & 58.64 & 315.43 & 65.88 & $2,712.85$ \\
\hline $\mathbf{2 0 2 4}$ & $\mathbf{3 , 1 5 4 . 7 3}$ & 58.88 & 315.38 & 65.58 & $2,714.89$ \\
\hline $\mathbf{2 0 2 5}$ & $\mathbf{3 , 1 5 6 . 5 5}$ & 59.13 & 315.31 & 65.28 & $2,716.83$ \\
\hline
\end{tabular}


Table A9: The Lower Range for the Total Tax Credits Earned by the Additional Renewable Electricity Generation due to a 25\% RPS in Michigan (Thousand 2011\$)

\begin{tabular}{|c|c|c|c|c|c|}
\hline Year & Total & Solar PV & Biomass & Landfill Gas & Wind (Onshore) \\
\hline $\mathbf{2 0 1 6}$ & $114,652.10$ & 766.45 & $1,509.15$ & 26.83 & $112,349.67$ \\
\hline $\mathbf{2 0 1 7}$ & $229,714.78$ & 537.76 & $3,096.58$ & 54.10 & $226,026.33$ \\
\hline $\mathbf{2 0 1 8}$ & $346,728.65$ & 849.48 & $4,765.89$ & 81.82 & $341,031.46$ \\
\hline $\mathbf{2 0 1 9}$ & $465,190.11$ & $1,193.53$ & $6,520.83$ & 109.99 & $457,365.75$ \\
\hline $\mathbf{2 0 2 0}$ & $585,106.18$ & $1,573.10$ & $8,365.34$ & 138.63 & $575,029.11$ \\
\hline $\mathbf{2 0 2 1}$ & $706,472.83$ & $1,981.05$ & $10,303.52$ & 167.72 & $694,020.54$ \\
\hline $\mathbf{2 0 2 2}$ & $829,301.95$ & $2,426.93$ & $12,339.65$ & 197.29 & $814,338.08$ \\
\hline $\mathbf{2 0 2 3}$ & $953,598.52$ & $2,914.18$ & $14,478.23$ & 227.33 & $935,978.78$ \\
\hline $\mathbf{2 0 2 4}$ & $1,079,366.90$ & $3,446.59$ & $16,723.93$ & 257.86 & $1,058,938.52$ \\
\hline $\mathbf{2 0 2 5}$ & $1,206,610.82$ & $4,028.27$ & $19,081.67$ & 288.87 & $1,183,212.01$ \\
\hline
\end{tabular}

Table A10: The Upper Range for the Total Tax Credits Earned by the Additional Renewable Electricity Generation due to a 25\% RPS in Michigan (Thousand 2011\$)

\begin{tabular}{|c|c|c|c|c|c|}
\hline Year & Total & Solar PV & Biomass & Landfill Gas & Wind (Onshore) \\
\hline $\mathbf{2 0 1 6}$ & $115,414.46$ & $1,528.81$ & $1,509.15$ & 26.83 & $112,349.67$ \\
\hline $\mathbf{2 0 1 7}$ & $230,249.67$ & $1,072.66$ & $3,096.58$ & 54.10 & $226,026.33$ \\
\hline $\mathbf{2 0 1 8}$ & $347,573.60$ & $1,694.43$ & $4,765.89$ & 81.82 & $341,031.46$ \\
\hline $\mathbf{2 0 1 9}$ & $466,377.28$ & $2,380.70$ & $6,520.83$ & 109.99 & $457,365.75$ \\
\hline $\mathbf{2 0 2 0}$ & $586,670.88$ & $3,137.81$ & $8,365.34$ & 138.63 & $575,029.11$ \\
\hline $\mathbf{2 0 2 1}$ & $708,453.88$ & $3,962.10$ & $10,303.52$ & 167.72 & $694,020.54$ \\
\hline $\mathbf{2 0 2 2}$ & $831,741.96$ & $4,866.93$ & $12,339.65$ & 197.29 & $814,338.08$ \\
\hline $\mathbf{2 0 2 3}$ & $956,544.29$ & $5,859.95$ & $14,478.23$ & 227.33 & $935,978.78$ \\
\hline $\mathbf{2 0 2 4}$ & $1,082,869.84$ & $6,949.53$ & $16,723.93$ & 257.86 & $1,058,938.52$ \\
\hline $\mathbf{2 0 2 5}$ & $1,210,727.39$ & $8,144.83$ & $19,081.67$ & 288.87 & $1,183,212.01$ \\
\hline
\end{tabular}


Table A11: The Lower Range for the Total Tax Credits Earned by Different Renewable Electricity Power Plants Under a 25\% RPS in Michigan (Million 2011\$)

\begin{tabular}{|l|c|c|c|c|c|}
\hline Year & Total & Solar PV & Biomass & Landfill Gas & Wind (Onshore) \\
\hline $\mathbf{2 0 1 6}$ & 778.47 & 9.24 & 41.40 & 8.76 & 719.07 \\
\hline $\mathbf{2 0 1 7}$ & 892.43 & 3.38 & 43.26 & 8.85 & 836.94 \\
\hline $\mathbf{2 0 1 8}$ & $1,014.02$ & 3.71 & 45.21 & 8.93 & 956.16 \\
\hline $\mathbf{2 0 1 9}$ & $1,137.09$ & 4.08 & 47.24 & 9.02 & $1,076.75$ \\
\hline $\mathbf{2 0 2 0}$ & $1,261.65$ & 4.48 & 49.37 & 9.11 & $1,198.69$ \\
\hline $\mathbf{2 0 2 1}$ & $1,387.68$ & 4.89 & 51.59 & 9.20 & $1,322.00$ \\
\hline $\mathbf{2 0 2 2}$ & $1,515.20$ & 5.34 & 53.91 & 9.30 & $1,446.65$ \\
\hline $\mathbf{2 0 2 3}$ & $1,644.23$ & 5.83 & 56.34 & 9.39 & $1,572.67$ \\
\hline $\mathbf{2 0 2 4}$ & $1,774.75$ & 6.37 & 58.87 & 9.48 & $1,700.03$ \\
\hline $\mathbf{2 0 2 5}$ & $1,906.79$ & 6.95 & 61.52 & 9.58 & $1,828.74$ \\
\hline
\end{tabular}

Table A12: The Upper Range for the Total Tax Credits Earned by Different Renewable Electricity Power Plants Under a 25\% RPS in Michigan (Million 2011\$)

\begin{tabular}{|c|c|c|c|c|c|}
\hline Year & Total & Solar PV & Biomass & Landfill Gas & Wind (Onshore) \\
\hline $\mathbf{2 0 1 6}$ & 787.66 & 18.43 & 41.40 & 8.76 & 719.07 \\
\hline $\mathbf{2 0 1 7}$ & 895.79 & 6.74 & 43.26 & 8.85 & 836.94 \\
\hline $\mathbf{2 0 1 8}$ & $1,017.71$ & 7.41 & 45.21 & 8.93 & 956.16 \\
\hline $\mathbf{2 0 1 9}$ & $1,141.15$ & 8.13 & 47.24 & 9.02 & $1,076.75$ \\
\hline $\mathbf{2 0 2 0}$ & $1,266.10$ & 8.93 & 49.37 & 9.11 & $1,198.69$ \\
\hline $\mathbf{2 0 2 1}$ & $1,392.57$ & 9.78 & 51.59 & 9.20 & $1,322.00$ \\
\hline $\mathbf{2 0 2 2}$ & $1,520.57$ & 10.71 & 53.91 & 9.30 & $1,446.65$ \\
\hline $\mathbf{2 0 2 3}$ & $1,650.12$ & 11.72 & 56.34 & 9.39 & $1,572.67$ \\
\hline $\mathbf{2 0 2 4}$ & $1,781.23$ & 12.84 & 58.87 & 9.48 & $1,700.03$ \\
\hline $\mathbf{2 0 2 5}$ & $1,913.90$ & 14.06 & 61.52 & 9.58 & $1,828.74$ \\
\hline
\end{tabular}


Table A13: The Lower Range for the Present Value of the Cost of Renewable Electricity Generation Under a 25\% RPS (Tax Credits Included Scenario)

(Million 2011 \$)

\begin{tabular}{|c|c|c|c|c|c|}
\hline Year & $\begin{array}{c}\text { Before } \\
\text { Discounting }\end{array}$ & $\mathbf{r}=\mathbf{0 . 1 0 \%}$ & $\mathbf{r}=\mathbf{0 . 1 1 \%}$ & $\mathbf{r}=\mathbf{0 . 0 9 \%}$ & $\mathbf{r}=\mathbf{0 . 1 5 \%}$ \\
\hline $\mathbf{2 0 1 6}$ & $1,821.92$ & $1,816.47$ & $1,815.92$ & $1,817.01$ & $1,813.75$ \\
\hline $\mathbf{2 0 1 7}$ & $2,098.71$ & $2,090.34$ & $2,089.50$ & $2,091.18$ & $2,086.17$ \\
\hline $\mathbf{2 0 1 8}$ & $2,372.99$ & $2,361.17$ & $2,359.99$ & $2,362.35$ & $2,355.28$ \\
\hline $\mathbf{2 0 1 9}$ & $2,650.97$ & $2,635.12$ & $2,633.54$ & $2,636.70$ & $2,627.24$ \\
\hline $\mathbf{2 0 2 0}$ & $2,932.69$ & $2,912.25$ & $2,910.21$ & $2,914.28$ & $2,902.08$ \\
\hline $\mathbf{2 0 2 1}$ & $3,180.00$ & $3,154.68$ & $3,152.16$ & $3,157.20$ & $3,142.10$ \\
\hline $\mathbf{2 0 2 2}$ & $3,424.34$ & $3,393.68$ & $3,390.63$ & $3,396.73$ & $3,378.46$ \\
\hline $\mathbf{2 0 2 3}$ & $3,665.64$ & $3,629.19$ & $3,625.56$ & $3,632.81$ & $3,611.11$ \\
\hline $\mathbf{2 0 2 4}$ & $3,903.82$ & $3,861.14$ & $3,856.90$ & $3,865.38$ & $3,839.99$ \\
\hline $\mathbf{2 0 2 5}$ & $4,138.81$ & $4,089.47$ & $4,084.57$ & $4,094.37$ & $4,065.03$ \\
\hline Total & N/A & $29,943.49$ & $29,918.98$ & $29,968.02$ & $29,821.20$ \\
\hline
\end{tabular}

Table A14: The Upper Range for the Present Value of the Cost of Renewable Electricity Generation Under a 25\% RPS (Tax Credits Included Scenario) (Million 2011 \$)

\begin{tabular}{|c|c|c|c|c|c|}
\hline Year & $\begin{array}{c}\text { Before } \\
\text { Discounting }\end{array}$ & $\mathbf{r = 0 . 1}$ & $\mathbf{r}=\mathbf{0 . 1 1}$ & $\mathbf{r}=\mathbf{0 . 0 9}$ & $\mathbf{r = 0 . 1 5}$ \\
\hline $\mathbf{2 0 1 6}$ & $2,777.57$ & $2,769.25$ & $2,768.42$ & $2,770.08$ & $2,765.11$ \\
\hline $\mathbf{2 0 1 7}$ & $3,201.88$ & $3,189.10$ & $3,187.83$ & $3,190.38$ & $3,182.74$ \\
\hline $\mathbf{2 0 1 8}$ & $3,619.54$ & $3,601.50$ & $3,599.70$ & $3,603.29$ & $3,592.51$ \\
\hline $\mathbf{2 0 1 9}$ & $4,042.91$ & $4,018.74$ & $4,016.33$ & $4,021.15$ & $4,006.72$ \\
\hline $\mathbf{2 0 2 0}$ & $4,472.08$ & $4,440.90$ & $4,437.80$ & $4,444.01$ & $4,425.41$ \\
\hline $\mathbf{2 0 2 1}$ & $4,868.93$ & $4,830.15$ & $4,826.30$ & $4,834.02$ & $4,810.90$ \\
\hline $\mathbf{2 0 2 2}$ & $5,264.95$ & $5,217.80$ & $5,213.11$ & $5,222.49$ & $5,194.40$ \\
\hline $\mathbf{2 0 2 3}$ & $5,660.09$ & $5,603.80$ & $5,598.21$ & $5,609.40$ & $5,575.89$ \\
\hline $\mathbf{2 0 2 4}$ & $6,054.34$ & $5,988.14$ & $5,981.57$ & $5,994.73$ & $5,955.34$ \\
\hline $\mathbf{2 0 2 5}$ & $6,447.67$ & $6,370.80$ & $6,363.17$ & $6,378.44$ & $6,332.74$ \\
\hline Total & N/A & $46,030.19$ & $45,992.43$ & $46,068.00$ & $45,841.75$ \\
\hline
\end{tabular}


Table A15: The Lower Range for the Additional Cost of Renewable Electricity Generation due to a 25\% RPS in Michigan (Tax Credits Included Scenario) (Million 2011\$)

\begin{tabular}{|c|c|c|c|c|c|}
\hline Year & $\begin{array}{c}\text { Before } \\
\text { Discounting }\end{array}$ & $\mathbf{r}=\mathbf{0 . 1}$ & $\mathbf{r}=\mathbf{0 . 1 1}$ & $\mathbf{r}=\mathbf{0 . 0 9}$ & $\mathbf{r}=\mathbf{0 . 1 5}$ \\
\hline $\mathbf{2 0 1 6}$ & 255.73 & 254.97 & 254.89 & 255.04 & 254.59 \\
\hline $\mathbf{2 0 1 7}$ & 516.02 & 513.96 & 513.76 & 514.17 & 512.93 \\
\hline $\mathbf{2 0 1 8}$ & 779.37 & 775.48 & 775.09 & 775.87 & 773.55 \\
\hline $\mathbf{2 0 1 9}$ & $1,046.33$ & $1,040.08$ & $1,039.45$ & $1,040.70$ & $1,036.96$ \\
\hline $\mathbf{2 0 2 0}$ & $1,316.96$ & $1,307.78$ & $1,306.87$ & $1,308.70$ & $1,303.22$ \\
\hline $\mathbf{2 0 2 1}$ & $1,572.55$ & $1,560.03$ & $1,558.78$ & $1,561.27$ & $1,553.81$ \\
\hline $\mathbf{2 0 2 2}$ & $1,825.36$ & $1,809.01$ & $1,807.39$ & $1,810.64$ & $1,800.90$ \\
\hline $\mathbf{2 0 2 3}$ & $2,075.32$ & $2,054.68$ & $2,052.63$ & $2,056.73$ & $2,044.45$ \\
\hline $\mathbf{2 0 2 4}$ & $2,322.36$ & $2,296.96$ & $2,294.44$ & $2,299.49$ & $2,284.38$ \\
\hline $\mathbf{2 0 2 5}$ & $2,566.39$ & $2,535.80$ & $2,532.76$ & $2,538.84$ & $2,520.65$ \\
\hline Total & N/A & $14,148.75$ & $14,136.06$ & $14,161.46$ & $14,085.44$ \\
\hline
\end{tabular}

Table A16: The Upper Range for the Additional Cost of Renewable Electricity Generation due to a 25\% RPS in Michigan (Tax Credits Included Scenario) (Million 2011\$)

\begin{tabular}{|c|c|c|c|c|c|}
\hline Year & $\begin{array}{c}\text { Before } \\
\text { Discounting }\end{array}$ & $\mathbf{r}=\mathbf{0 . 1}$ & $\mathbf{r = 0 . 1 1}$ & $\mathbf{r}=\mathbf{0 . 0 9}$ & $\mathbf{r = 0 . 1 5}$ \\
\hline $\mathbf{2 0 1 6}$ & 388.99 & 387.83 & 387.71 & 387.94 & 387.25 \\
\hline $\mathbf{2 0 1 7}$ & 785.46 & 782.33 & 782.02 & 782.64 & 780.77 \\
\hline $\mathbf{2 0 1 8}$ & $1,186.43$ & $1,180.51$ & $1,179.92$ & $1,181.10$ & $1,177.57$ \\
\hline $\mathbf{2 0 1 9}$ & $1,592.99$ & $1,583.46$ & $1,582.52$ & $1,584.41$ & $1,578.73$ \\
\hline $\mathbf{2 0 2 0}$ & $2,005.23$ & $1,991.25$ & $1,989.86$ & $1,992.64$ & $1,984.30$ \\
\hline $\mathbf{2 0 2 1}$ & $2,404.47$ & $2,385.32$ & $2,383.42$ & $2,387.23$ & $2,375.81$ \\
\hline $\mathbf{2 0 2 2}$ & $2,803.03$ & $2,777.93$ & $2,775.43$ & $2,780.43$ & $2,765.47$ \\
\hline $\mathbf{2 0 2 3}$ & $3,200.87$ & $3,169.04$ & $3,165.87$ & $3,172.21$ & $3,153.25$ \\
\hline $\mathbf{2 0 2 4}$ & $3,597.97$ & $3,558.63$ & $3,554.72$ & $3,562.54$ & $3,539.13$ \\
\hline $\mathbf{2 0 2 5}$ & $3,994.30$ & $3,946.67$ & $3,941.95$ & $3,951.41$ & $3,923.09$ \\
\hline Total & N/A & $21,762.97$ & $21,743.41$ & $21,782.56$ & $21,665.37$ \\
\hline
\end{tabular}









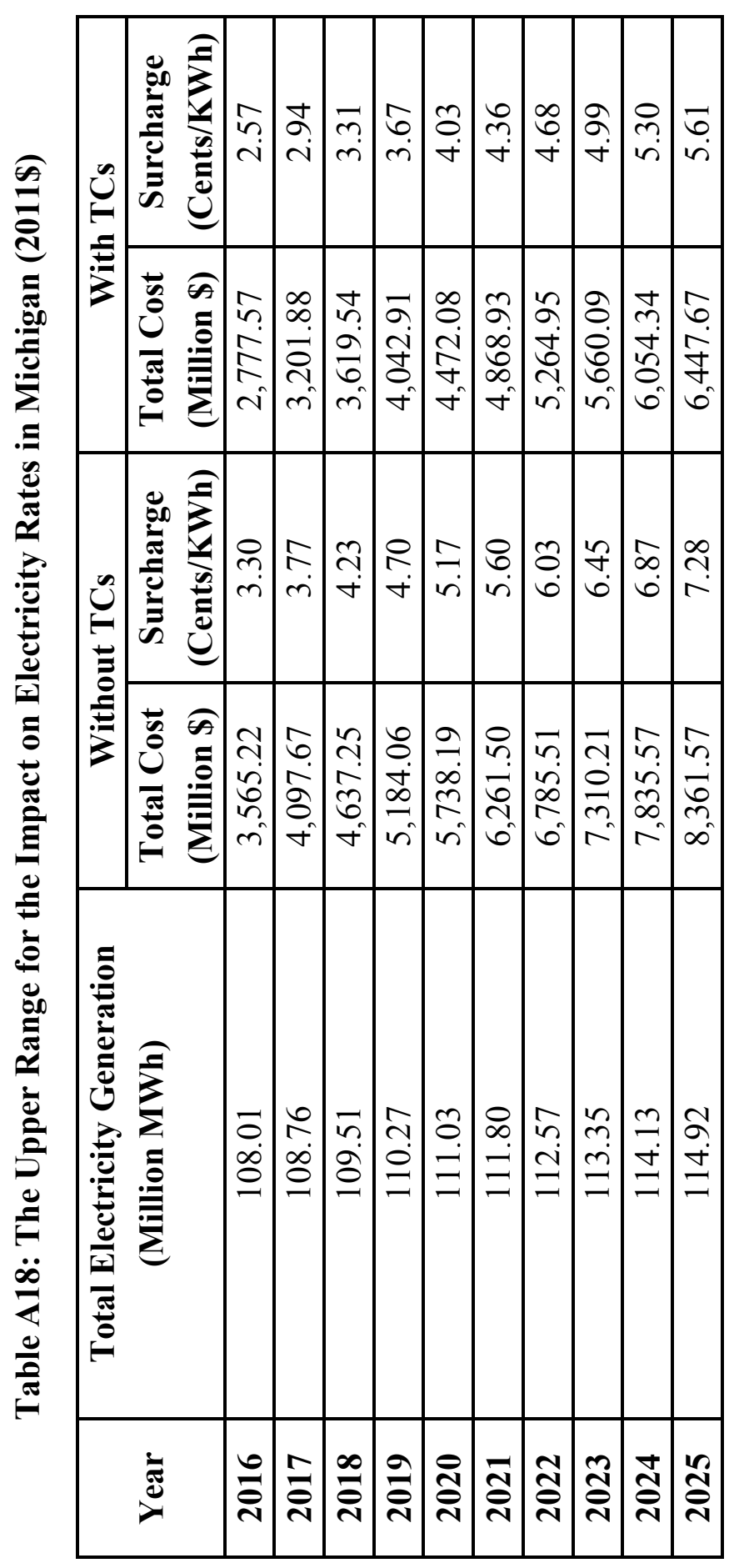


Table A19: The Lower Range for the Avoided Cost of Electricity Generation Under a 25\% RPS in Michigan (Million 2011\$)

\begin{tabular}{|c|c|c|c|}
\hline Year & Total & $\begin{array}{c}\text { Conventional } \\
\text { Coal }\end{array}$ & $\begin{array}{c}\text { Natural Gas-fired } \\
\text { (Advanced Combined Cycle) }\end{array}$ \\
\hline $\mathbf{2 0 1 6}$ & $\mathbf{4 4 4 . 5 4}$ & 438.76 & 5.78 \\
\hline $\mathbf{2 0 1 7}$ & $\mathbf{8 9 4 . 7 5}$ & 882.95 & 11.80 \\
\hline $\mathbf{2 0 1 8}$ & $\mathbf{1 , 3 5 0 . 6 8}$ & $1,332.61$ & 18.08 \\
\hline $\mathbf{2 0 1 9}$ & $\mathbf{1 , 8 1 2 . 3 7}$ & $1,787.76$ & 24.61 \\
\hline $\mathbf{2 0 2 0}$ & $\mathbf{2 , 2 7 9 . 8 6}$ & $2,248.45$ & 31.40 \\
\hline $\mathbf{2 0 2 1}$ & $\mathbf{2 , 7 2 6 . 4 0}$ & $2,687.41$ & 38.99 \\
\hline $\mathbf{2 0 2 2}$ & $\mathbf{3 , 1 6 9 . 5 3}$ & $3,122.48$ & 47.05 \\
\hline $\mathbf{2 0 2 3}$ & $\mathbf{3 , 6 0 9 . 1 3}$ & $3,553.52$ & 55.60 \\
\hline $\mathbf{2 0 2 4}$ & $\mathbf{4 , 0 4 5 . 0 8}$ & $3,980.40$ & 64.68 \\
\hline $\mathbf{2 0 2 5}$ & $\mathbf{4 , 4 7 7 . 2 7}$ & $4,402.98$ & 74.30 \\
\hline
\end{tabular}

Table A20: The Upper Range for the Avoided Cost of Electricity Generation Under a 25\% RPS in Michigan (Million 2011\$)

\begin{tabular}{|c|c|c|c|}
\hline Year & Total & $\begin{array}{c}\text { Conventional } \\
\text { Coal }\end{array}$ & $\begin{array}{c}\text { Natural Gas-fired } \\
\text { (Advanced Combined Cycle) }\end{array}$ \\
\hline $\mathbf{2 0 1 6}$ & $\mathbf{5 8 7 . 2 8}$ & 579.95 & 7.33 \\
\hline $\mathbf{2 0 1 7}$ & $\mathbf{1 , 1 8 2 . 0 4}$ & $1,167.07$ & 14.97 \\
\hline $\mathbf{2 0 1 8}$ & $\mathbf{1 , 7 8 4 . 3 5}$ & $1,761.42$ & 22.93 \\
\hline $\mathbf{2 0 1 9}$ & $\mathbf{2 , 3 9 4 . 2 5}$ & $2,363.04$ & 31.21 \\
\hline $\mathbf{2 0 2 0}$ & $\mathbf{3 , 0 1 1 . 8 1}$ & $2,971.98$ & 39.83 \\
\hline $\mathbf{2 0 2 1}$ & $\mathbf{3 , 6 1 0 . 2 8}$ & $3,560.97$ & 49.31 \\
\hline $\mathbf{2 0 2 2}$ & $\mathbf{4 , 2 0 7 . 2 2}$ & $4,147.88$ & 59.34 \\
\hline $\mathbf{2 0 2 3}$ & $\mathbf{4 , 8 0 2 . 5 2}$ & $4,732.57$ & 69.95 \\
\hline $\mathbf{2 0 2 4}$ & $\mathbf{5 , 3 9 6 . 0 8}$ & $5,314.92$ & 81.16 \\
\hline $\mathbf{2 0 2 5}$ & $\mathbf{5 , 9 8 7 . 7 9}$ & $5,894.81$ & 92.99 \\
\hline
\end{tabular}


Table A21: The Lower Range for the Required Backup Electricity Generation in Michigan (5\% Backup Capacity) (Thousand MWh)

\begin{tabular}{|c|c|c|c|}
\hline Year & Total & Coal Power Plants & Natural Gas Power Plants \\
\hline $\mathbf{2 0 1 6}$ & $\mathbf{2 4 5 . 3 7}$ & 240.64 & 4.73 \\
\hline $\mathbf{2 0 1 7}$ & $\mathbf{4 9 3 . 7 5}$ & 484.10 & 9.65 \\
\hline $\mathbf{2 0 1 8}$ & $\mathbf{7 4 5 . 1 5}$ & 730.37 & 14.78 \\
\hline $\mathbf{2 0 1 9}$ & $\mathbf{9 9 9 . 5 8}$ & 979.47 & 20.11 \\
\hline $\mathbf{2 0 2 0}$ & $\mathbf{1 , 2 5 7 . 0 5}$ & $1,231.40$ & 25.66 \\
\hline $\mathbf{2 0 2 1}$ & $\mathbf{1 , 5 1 7 . 5 9}$ & $1,486.17$ & 31.42 \\
\hline $\mathbf{2 0 2 2}$ & $\mathbf{1 , 7 8 1 . 2 0}$ & $1,743.80$ & 37.41 \\
\hline $\mathbf{2 0 2 3}$ & $\mathbf{2 , 0 4 7 . 9 0}$ & $2,004.27$ & 43.63 \\
\hline $\mathbf{2 0 2 4}$ & $\mathbf{2 , 3 1 7 . 6 9}$ & $2,267.61$ & 50.08 \\
\hline $\mathbf{2 0 2 5}$ & $\mathbf{2 , 5 9 0 . 5 9}$ & $2,533.81$ & 56.79 \\
\hline
\end{tabular}

Table A22: The Upper Range for the Required Backup Electricity Generation in Michigan (10\% Backup Capacity) (Thousand MWh)

\begin{tabular}{|c|c|c|c|}
\hline Year & Total & Coal Power Plants & Natural Gas Power Plants \\
\hline $\mathbf{2 0 1 6}$ & $\mathbf{4 9 0 . 7 5}$ & 481.29 & 9.46 \\
\hline $\mathbf{2 0 1 7}$ & $\mathbf{9 8 7 . 5 0}$ & 968.20 & 19.31 \\
\hline $\mathbf{2 0 1 8}$ & $\mathbf{1 , 4 9 0 . 3 0}$ & $1,460.74$ & 29.56 \\
\hline $\mathbf{2 0 1 9}$ & $\mathbf{1 , 9 9 9 . 1 6}$ & $1,958.93$ & 40.22 \\
\hline $\mathbf{2 0 2 0}$ & $\mathbf{2 , 5 1 4 . 1 1}$ & $2,462.80$ & 51.31 \\
\hline $\mathbf{2 0 2 1}$ & $\mathbf{3 , 0 3 5 . 1 8}$ & $2,972.35$ & 62.84 \\
\hline $\mathbf{2 0 2 2}$ & $\mathbf{3 , 5 6 2 . 4 1}$ & $3,487.59$ & 74.81 \\
\hline $\mathbf{2 0 2 3}$ & $\mathbf{4 , 0 9 5 . 8 0}$ & $4,008.55$ & 87.25 \\
\hline $\mathbf{2 0 2 4}$ & $\mathbf{4 , 6 3 5 . 3 8}$ & $4,535.22$ & 100.17 \\
\hline $\mathbf{2 0 2 5}$ & $\mathbf{5 , 1 8 1 . 1 9}$ & $5,067.62$ & 113.57 \\
\hline
\end{tabular}


Table A23: The Lower Range for the Cost of Backup Capacity Compensating for Intermittent Renewable Electricity Generation Technologies Under a 25\% RPS in Michigan (5\% Backup Capacity and Lower LECs) (Million 2011\$)

\begin{tabular}{|c|c|c|c|}
\hline Year & Total & Coal Power Plants & Natural Gas Power Plants \\
\hline $\mathbf{2 0 1 6}$ & $\mathbf{2 1 . 8 2}$ & 21.54 & 0.28 \\
\hline $\mathbf{2 0 1 7}$ & $\mathbf{4 3 . 9 1}$ & 43.33 & 0.58 \\
\hline $\mathbf{2 0 1 8}$ & $\mathbf{6 6 . 2 5}$ & 65.37 & 0.89 \\
\hline $\mathbf{2 0 1 9}$ & $\mathbf{8 8 . 8 7}$ & 87.66 & 1.21 \\
\hline $\mathbf{2 0 2 0}$ & $\mathbf{1 1 1 . 7 5}$ & 110.21 & 1.54 \\
\hline $\mathbf{2 0 2 1}$ & $\mathbf{1 3 3 . 5 9}$ & 131.68 & 1.91 \\
\hline $\mathbf{2 0 2 2}$ & $\mathbf{1 5 5 . 2 4}$ & 152.93 & 2.30 \\
\hline $\mathbf{2 0 2 3}$ & $\mathbf{1 7 6 . 6 9}$ & 173.97 & 2.72 \\
\hline $\mathbf{2 0 2 4}$ & $\mathbf{1 9 7 . 9 5}$ & 194.79 & 3.17 \\
\hline $\mathbf{2 0 2 5}$ & $\mathbf{2 1 9 . 0 1}$ & 215.37 & 3.63 \\
\hline
\end{tabular}

Table A24: The Upper Range for the Cost of Backup Capacity Compensating for Intermittent Renewable Electricity Generation Technologies Under a 25\% RPS in Michigan (10\% Backup Capacity and Upper LECs) (Million 2011\$)

\begin{tabular}{|c|c|c|c|}
\hline Year & Total & Coal Power Plants & Natural Gas Power Plants \\
\hline $\mathbf{2 0 1 6}$ & $\mathbf{5 7 . 6 6}$ & 56.94 & 0.72 \\
\hline $\mathbf{2 0 1 7}$ & $\mathbf{1 1 6 . 0 1}$ & 114.54 & 1.47 \\
\hline $\mathbf{2 0 1 8}$ & $\mathbf{1 7 5 . 0 5}$ & 172.81 & 2.25 \\
\hline $\mathbf{2 0 1 9}$ & $\mathbf{2 3 4 . 8 0}$ & 231.74 & 3.06 \\
\hline $\mathbf{2 0 2 0}$ & $\mathbf{2 9 5 . 2 5}$ & 291.35 & 3.90 \\
\hline $\mathbf{2 0 2 1}$ & $\mathbf{3 5 3 . 7 9}$ & 348.95 & 4.83 \\
\hline $\mathbf{2 0 2 2}$ & $\mathbf{4 1 2 . 1 2}$ & 406.30 & 5.81 \\
\hline $\mathbf{2 0 2 3}$ & $\mathbf{4 7 0 . 2 4}$ & 463.39 & 6.85 \\
\hline $\mathbf{2 0 2 4}$ & $\mathbf{5 2 8 . 1 3}$ & 520.19 & 7.94 \\
\hline $\mathbf{2 0 2 5}$ & $\mathbf{5 8 5 . 7 9}$ & 576.69 & 9.10 \\
\hline
\end{tabular}


Table A25: The Lower Range for the Net Renewable Electricity Generation Cost Under a 25\% RPS in Michigan (Million 2011\$)

\begin{tabular}{|c|c|c|c|c|}
\hline Year & NREGC & ACREG & CCIT & ACEG \\
\hline $\mathbf{2 0 1 6}$ & $(52.33)$ & 370.39 & 21.82 & 444.54 \\
\hline $\mathbf{2 0 1 7}$ & $(105.11)$ & 745.73 & 43.91 & 894.75 \\
\hline $\mathbf{2 0 1 8}$ & $(158.33)$ & $1,126.10$ & 66.25 & $1,350.68$ \\
\hline $\mathbf{2 0 1 9}$ & $(211.98)$ & $1,511.52$ & 88.87 & $1,812.37$ \\
\hline $\mathbf{2 0 2 0}$ & $(266.04)$ & $1,902.07$ & 111.75 & $2,279.86$ \\
\hline $\mathbf{2 0 2 1}$ & $(313.79)$ & $2,279.02$ & 133.59 & $2,726.40$ \\
\hline $\mathbf{2 0 2 2}$ & $(359.63)$ & $2,654.66$ & 155.24 & $3,169.53$ \\
\hline $\mathbf{2 0 2 3}$ & $(403.52)$ & $3,028.92$ & 176.69 & $3,609.13$ \\
\hline $\mathbf{2 0 2 4}$ & $(445.41)$ & $3,401.72$ & 197.95 & $4,045.08$ \\
\hline $\mathbf{2 0 2 5}$ & $(485.26)$ & $3,773.01$ & 219.01 & $4,477.27$ \\
\hline
\end{tabular}

Table A26: The Upper Range for the Net Renewable Electricity Generation Cost Under a 25\% RPS in Michigan (Million 2011\$)

\begin{tabular}{|c|c|c|c|c|}
\hline Year & NREGC & ACREG & CCIT & ACEG \\
\hline $\mathbf{2 0 1 6}$ & $(25.22)$ & 504.41 & 57.66 & 587.28 \\
\hline $\mathbf{2 0 1 7}$ & $(50.33)$ & $1,015.71$ & 116.01 & $1,182.04$ \\
\hline $\mathbf{2 0 1 8}$ & $(75.29)$ & $1,534.00$ & 175.05 & $1,784.35$ \\
\hline $\mathbf{2 0 1 9}$ & $(100.08)$ & $2,059.37$ & 234.80 & $2,394.25$ \\
\hline $\mathbf{2 0 2 0}$ & $(124.65)$ & $2,591.90$ & 295.25 & $3,011.81$ \\
\hline $\mathbf{2 0 2 1}$ & $(143.57)$ & $3,112.93$ & 353.79 & $3,610.28$ \\
\hline $\mathbf{2 0 2 2}$ & $(160.33)$ & $3,634.77$ & 412.12 & $4,207.22$ \\
\hline $\mathbf{2 0 2 3}$ & $(174.87)$ & $4,157.42$ & 470.24 & $4,802.52$ \\
\hline $\mathbf{2 0 2 4}$ & $(187.11)$ & $4,680.84$ & 528.13 & $5,396.08$ \\
\hline $\mathbf{2 0 2 5}$ & $(196.98)$ & $5,205.02$ & 585.79 & $5,987.79$ \\
\hline
\end{tabular}


Table A27: The Lower Range for the Net Renewable Electricity Generation Cost Under a 25\% RPS in Michigan (Tax Credits Included Scenario) (Million 2011\$)

\begin{tabular}{|c|c|c|c|c|}
\hline Year & NREGC & ACREG & CCIT & ACEG \\
\hline $\mathbf{2 0 1 6}$ & $(166.98)$ & 255.73 & 21.82 & 444.54 \\
\hline $\mathbf{2 0 1 7}$ & $(334.83)$ & 516.02 & 43.91 & 894.75 \\
\hline $\mathbf{2 0 1 8}$ & $(505.06)$ & 779.37 & 66.25 & $1,350.68$ \\
\hline $\mathbf{2 0 1 9}$ & $(677.17)$ & $1,046.33$ & 88.87 & $1,812.37$ \\
\hline $\mathbf{2 0 2 0}$ & $(851.14)$ & $1,316.96$ & 111.75 & $2,279.86$ \\
\hline $\mathbf{2 0 2 1}$ & $(1,020.26)$ & $1,572.55$ & 133.59 & $2,726.40$ \\
\hline $\mathbf{2 0 2 2}$ & $(1,188.93)$ & $1,825.36$ & 155.24 & $3,169.53$ \\
\hline $\mathbf{2 0 2 3}$ & $(1,357.11)$ & $2,075.32$ & 176.69 & $3,609.13$ \\
\hline $\mathbf{2 0 2 4}$ & $(1,524.77)$ & $2,322.36$ & 197.95 & $4,045.08$ \\
\hline $\mathbf{2 0 2 5}$ & $(1,691.87)$ & $2,566.39$ & 219.01 & $4,477.27$ \\
\hline
\end{tabular}

Table A28: The Upper Range for the Net Renewable Electricity Generation Cost Under a 25\% RPS in Michigan (Tax Credits Included Scenario) (Thousand 2011\$)

\begin{tabular}{|c|c|c|c|c|}
\hline Year & NREGC & ACREG & CCIT & ACEG \\
\hline $\mathbf{2 0 1 6}$ & $(140.63)$ & 388.99 & 57.66 & 587.28 \\
\hline $\mathbf{2 0 1 7}$ & $(280.58)$ & 785.46 & 116.01 & $1,182.04$ \\
\hline $\mathbf{2 0 1 8}$ & $(422.87)$ & $1,186.43$ & 175.05 & $1,784.35$ \\
\hline $\mathbf{2 0 1 9}$ & $(566.46)$ & $1,592.99$ & 234.80 & $2,394.25$ \\
\hline $\mathbf{2 0 2 0}$ & $(711.33)$ & $2,005.23$ & 295.25 & $3,011.81$ \\
\hline $\mathbf{2 0 2 1}$ & $(852.02)$ & $2,404.47$ & 353.79 & $3,610.28$ \\
\hline $\mathbf{2 0 2 2}$ & $(992.07)$ & $2,803.03$ & 412.12 & $4,207.22$ \\
\hline $\mathbf{2 0 2 3}$ & $(1,131.42)$ & $3,200.87$ & 470.24 & $4,802.52$ \\
\hline $\mathbf{2 0 2 4}$ & $(1,269.98)$ & $3,597.97$ & 528.13 & $5,396.08$ \\
\hline $\mathbf{2 0 2 5}$ & $(1,407.71)$ & $3,994.30$ & 585.79 & $5,987.79$ \\
\hline
\end{tabular}




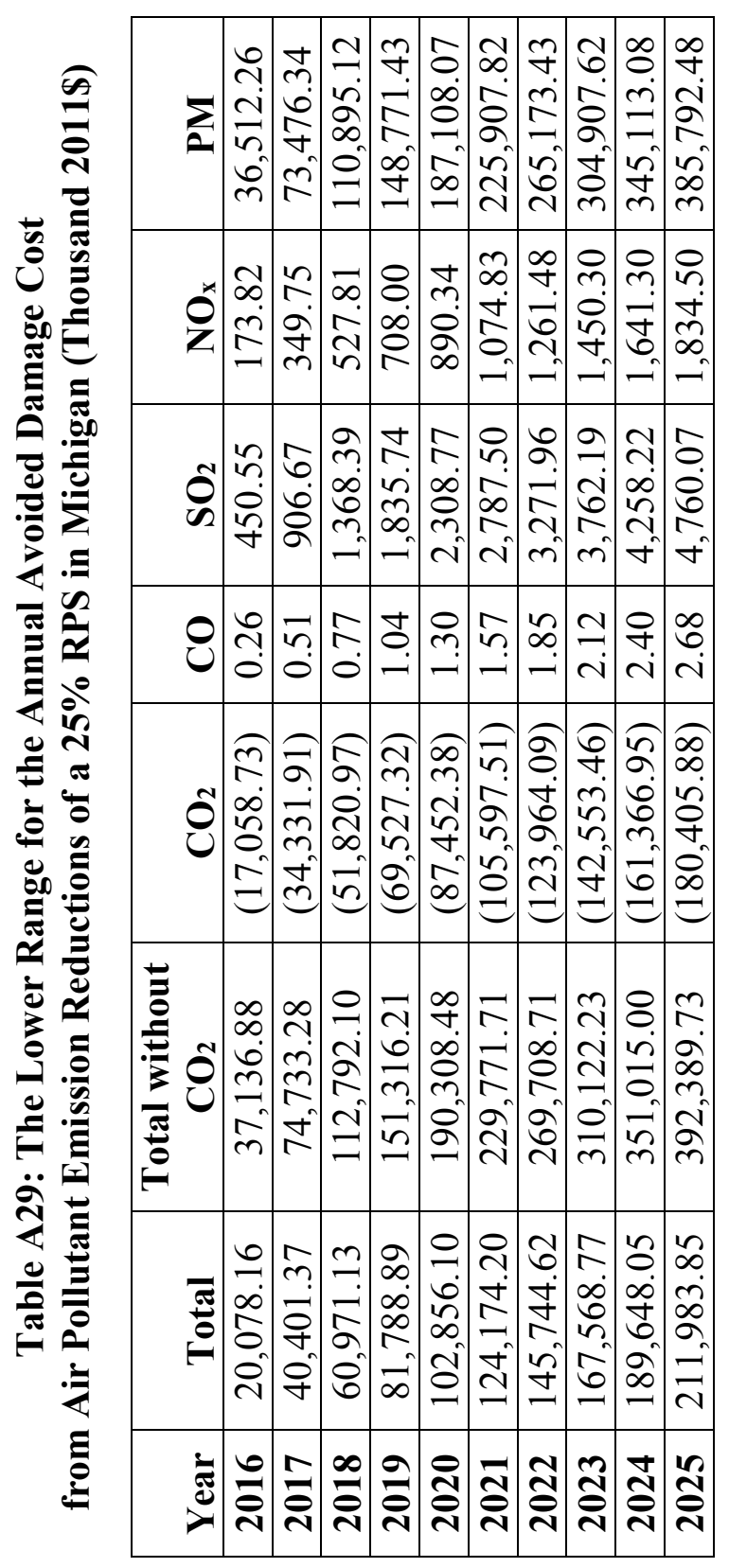




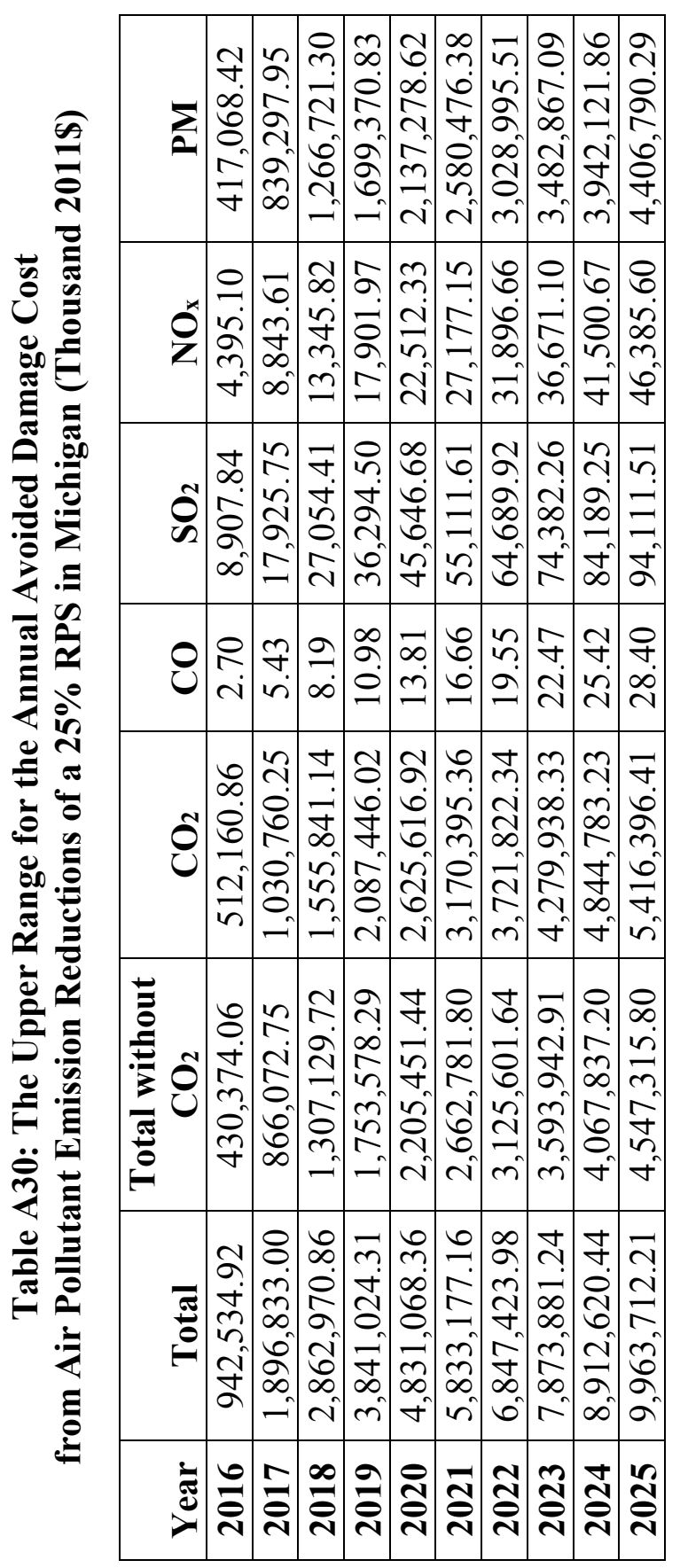




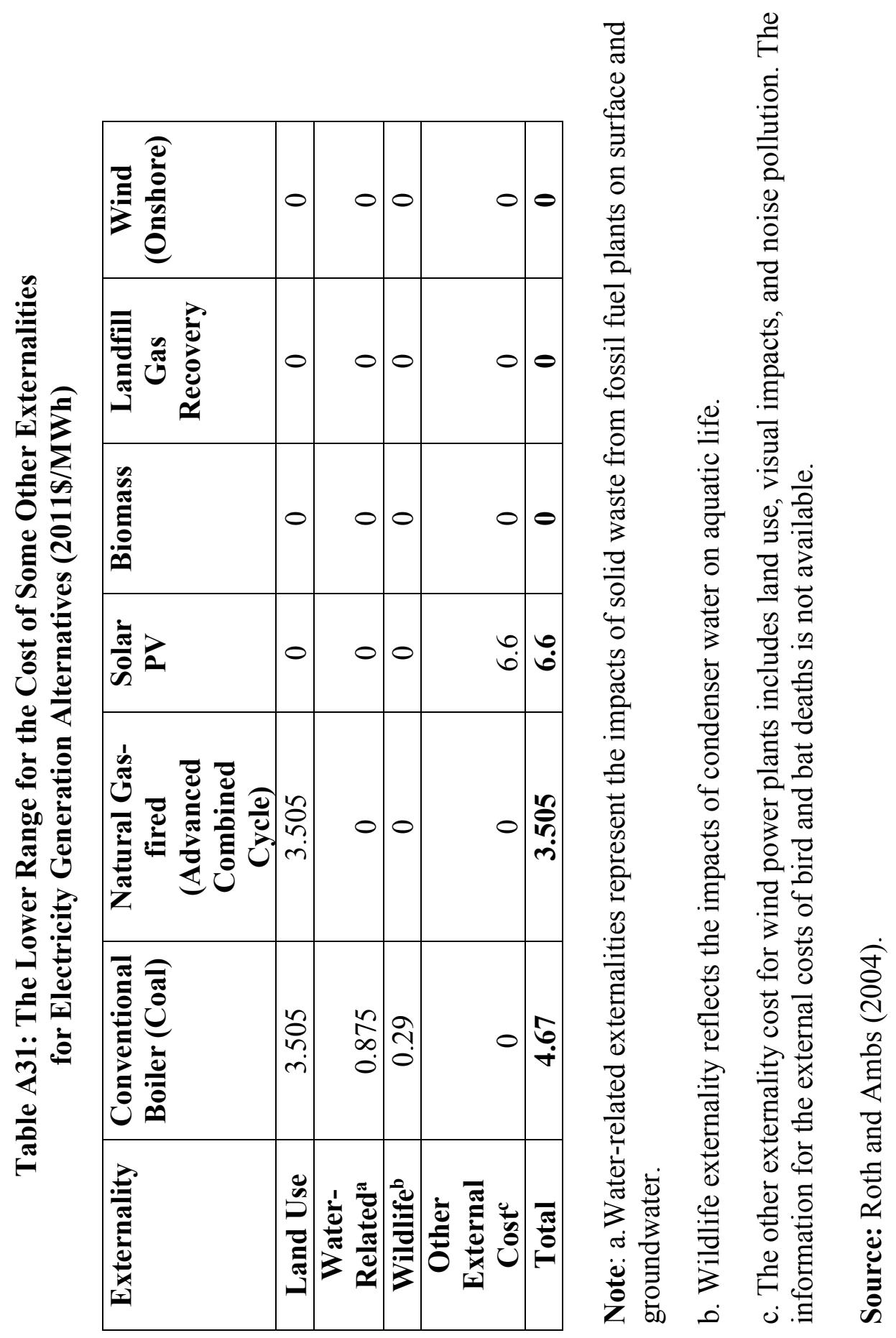




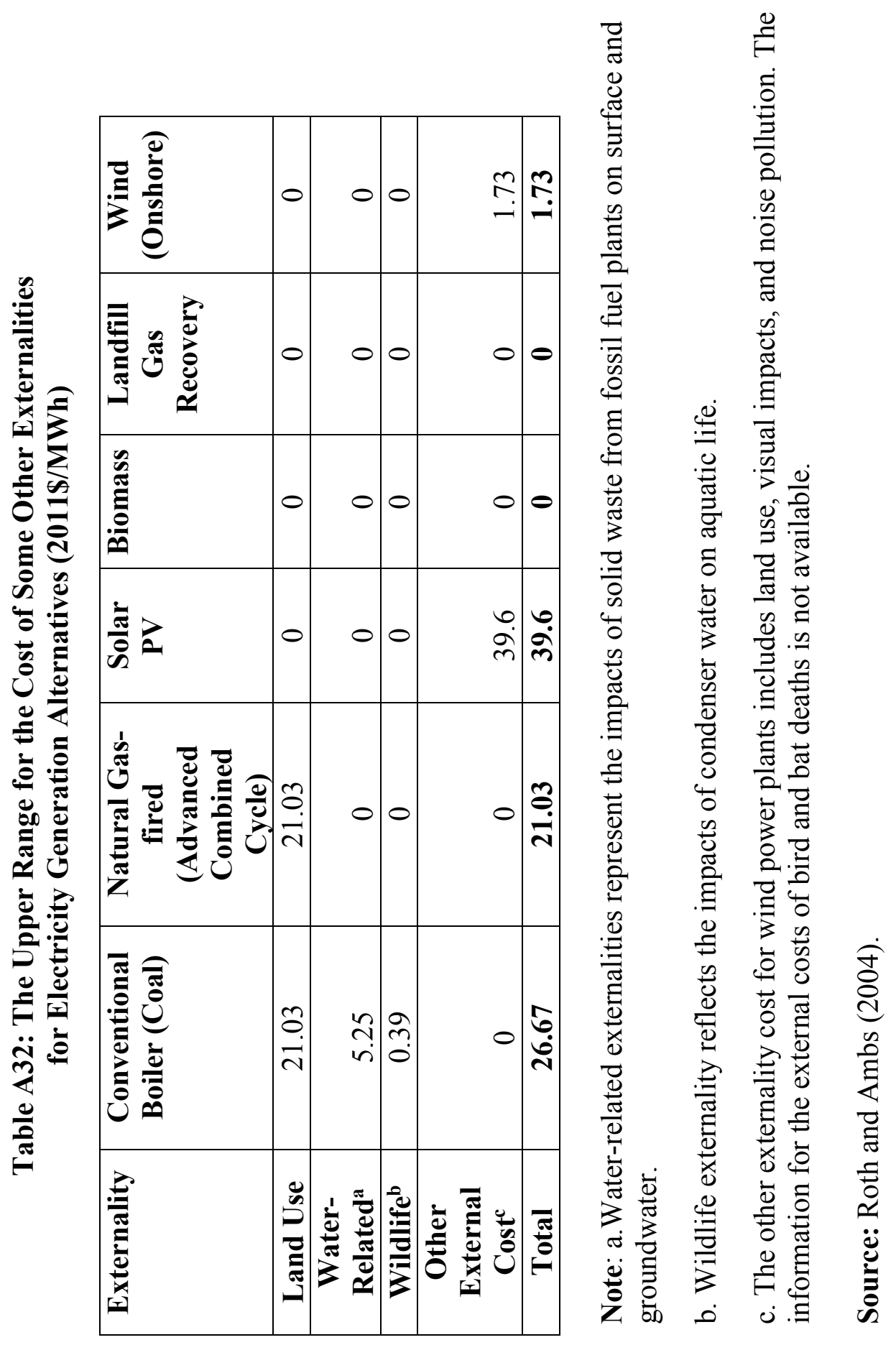


Table A33: The Lower Range of Avoided Cost of Other Externalities Under a 25\% RPS in Michigan (Million 2011\$)

\begin{tabular}{|c|c|c|c|c|c|c|c|}
\hline Year & Total & $\begin{array}{c}\text { Solar } \\
\text { PV }\end{array}$ & Biomass & $\begin{array}{c}\text { Landfill } \\
\text { Gas }\end{array}$ & $\begin{array}{c}\text { Wind } \\
\text { (Onshore) }\end{array}$ & Coal & $\begin{array}{c}\text { Natural } \\
\text { Gas }\end{array}$ \\
\hline $\mathbf{2 0 1 6}$ & $\mathbf{2 3 . 0 8}$ & $(0.15)$ & - & - & - & 22.89 & 0.34 \\
\hline $\mathbf{2 0 1 7}$ & $\mathbf{4 6 . 4 5}$ & $(0.32)$ & - & - & - & 46.07 & 0.69 \\
\hline $\mathbf{2 0 1 8}$ & $\mathbf{7 0 . 0 9}$ & $(0.50)$ & - & - & - & 69.53 & 1.06 \\
\hline $\mathbf{2 0 1 9}$ & $\mathbf{9 4 . 0 2}$ & $(0.70)$ & - & - & - & 93.28 & 1.44 \\
\hline $\mathbf{2 0 2 0}$ & $\mathbf{1 1 8 . 2 3}$ & $(0.92)$ & - & - & - & 117.32 & 1.83 \\
\hline $\mathbf{2 0 2 1}$ & $\mathbf{1 4 2 . 7 3}$ & $(1.17)$ & - & - & - & 141.65 & 2.25 \\
\hline $\mathbf{2 0 2 2}$ & $\mathbf{1 6 7 . 5 1}$ & $(1.44)$ & - & - & - & 166.27 & 2.68 \\
\hline $\mathbf{2 0 2 3}$ & $\mathbf{1 9 2 . 5 7}$ & $(1.74)$ & - & - & - & 191.19 & 3.12 \\
\hline $\mathbf{2 0 2 4}$ & $\mathbf{2 1 7 . 9 2}$ & $(2.07)$ & - & - & - & 216.40 & 3.59 \\
\hline $\mathbf{2 0 2 5}$ & $\mathbf{2 4 3 . 5 5}$ & $(2.43)$ & - & - & - & 241.90 & 4.07 \\
\hline
\end{tabular}

Table A34: The Upper Range of Avoided Cost of Other Externalities Under a 25\% RPS in Michigan (Million 2011\$)

\begin{tabular}{|c|c|c|c|c|c|c|c|}
\hline Year & Total & $\begin{array}{c}\text { Solar } \\
\text { PV }\end{array}$ & Biomass & $\begin{array}{c}\text { Landfill } \\
\text { Gas }\end{array}$ & $\begin{array}{c}\text { Wind } \\
\text { (Onshore) }\end{array}$ & Coal & $\begin{array}{c}\text { Natural } \\
\text { Gas }\end{array}$ \\
\hline $\mathbf{2 0 1 6}$ & $\mathbf{1 2 3 . 4 2}$ & $(0.90)$ & - & - & $(8.45)$ & 130.75 & 2.03 \\
\hline $\mathbf{2 0 1 7}$ & $\mathbf{2 4 8 . 3 5}$ & $(1.89)$ & - & - & $(17.00)$ & 263.11 & 4.14 \\
\hline $\mathbf{2 0 1 8}$ & $\mathbf{3 7 4 . 8 0}$ & $(2.99)$ & - & - & $(25.65)$ & 397.10 & 6.34 \\
\hline $\mathbf{2 0 1 9}$ & $\mathbf{5 0 2 . 7 6}$ & $(4.20)$ & - & - & $(34.40)$ & 532.73 & 8.63 \\
\hline $\mathbf{2 0 2 0}$ & $\mathbf{6 3 2 . 2 3}$ & $(5.54)$ & - & - & $(43.25)$ & 670.01 & 11.01 \\
\hline $\mathbf{2 0 2 1}$ & $\mathbf{7 6 3 . 2 3}$ & $(7.01)$ & - & - & $(52.20)$ & 808.95 & 13.49 \\
\hline $\mathbf{2 0 2 2}$ & $\mathbf{8 9 5 . 7 4}$ & $(8.63)$ & - & - & $(61.25)$ & 949.56 & 16.06 \\
\hline $\mathbf{2 0 2 3}$ & $\mathbf{1 , 0 2 9 . 7 6}$ & $(10.42)$ & - & - & $(70.40)$ & $1,091.85$ & 18.74 \\
\hline $\mathbf{2 0 2 4}$ & $\mathbf{1 , 1 6 5 . 3 0}$ & $(12.40)$ & - & - & $(79.65)$ & $1,235.82$ & 21.52 \\
\hline $\mathbf{2 0 2 5}$ & $\mathbf{1 , 3 0 2 . 3 5}$ & $(14.57)$ & - & - & $(89.00)$ & $1,381.50$ & 24.41 \\
\hline
\end{tabular}

